\title{
Review
}

\section{RTK Inhibitors in Melanoma: From Bench to Bedside}

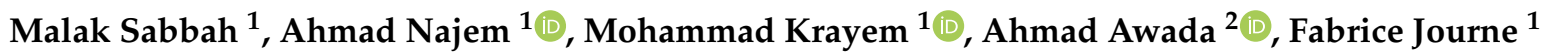 \\ and Ghanem E. Ghanem ${ }^{1, *}$ \\ 1 Laboratory of Oncology and Experimental Surgery, Institut Jules Bordet, Université Libre de Bruxelles, \\ 1000 Brussels, Belgium; malak.sabbah@ulb.be (M.S.); ahmad.najem@bordet.be (A.N.); \\ mohammad.krayem@bordet.be (M.K.); fabrice.journe@bordet.be (F.J.) \\ 2 Medical Oncolgy Clinic, Institut Jules Bordet, Université Libre de Bruxelles, 1000 Brussels, Belgium; \\ ahmad.awada@bordet.be \\ * Correspondence: gghanem@ulb.ac.be
}

Citation: Sabbah, M.; Najem, A.; Krayem, M.; Awada, A.; Journe, F.; Ghanem, G.E. RTK Inhibitors in Melanoma: From Bench to Bedside. Cancers 2021, 13, 1685. https:/ / doi.org/10.3390/cancers13071685

Academic Editor: David Wong

Received: 9 February 2021

Accepted: 15 March 2021

Published: 2 April 2021

Publisher's Note: MDPI stays neutral with regard to jurisdictional claims in published maps and institutional affiliations.

Copyright: (c) 2021 by the authors. Licensee MDPI, Basel, Switzerland. This article is an open access article distributed under the terms and conditions of the Creative Commons Attribution (CC BY) license (https:/ / creativecommons.org/licenses/by/ $4.0 /)$.
Simple Summary: Receptor tyrosine kinases (RTKs) have long been demonstrated to play key roles in melanoma development. RTK activation requires dimerization and intracellular tyrosine transphosphorylation leading to downstream signaling pathways activation. As RTKs show different structures, mechanism of activation could differ. In this review, we will discuss the structure and specific mechanism of activation of each RTK, and its alteration associated with stage of the disease. Additionally, we summarize the effect of RTK inhibitors tested in preclinical and clinical melanoma studies indicating the reason, the reported results, and the rational approaches for combination strategies based on RTK inhibition in melanoma.

Abstract: MAPK (mitogen activated protein kinase) and PI3K/AKT (Phosphatidylinositol-3-Kinase and Protein Kinase B) pathways play a key role in melanoma progression and metastasis that are regulated by receptor tyrosine kinases (RTKs). Although RTKs are mutated in a small percentage of melanomas, several receptors were found up regulated/altered in various stages of melanoma initiation, progression, or metastasis. Targeting RTKs remains a significant challenge in melanoma, due to their variable expression across different melanoma stages of progression and among melanoma subtypes that consequently affect response to treatment and disease progression. In this review, we discuss in details the activation mechanism of several key RTKs: type III: c-KIT (mast/stem cell growth factor receptor); type I: EGFR (Epidermal growth factor receptor); type VIII: HGFR (hepatocyte growth factor receptor); type V: VEGFR (Vascular endothelial growth factor), structure variants, the function of their structural domains, and their alteration and its association with melanoma initiation and progression. Furthermore, several RTK inhibitors targeting the same receptor were tested alone or in combination with other therapies, yielding variable responses among different melanoma groups. Here, we classified RTK inhibitors by families and summarized all tested drugs in melanoma indicating the rationale behind the use of these drugs in each melanoma subgroups from preclinical studies to clinical trials with a specific focus on their purpose of treatment, resulted effect, and outcomes.

Keywords: RTKs; RTK inhibitors; resistance; drug combination; melanoma; c-KIT; EGFR; HGFR (c-Met); VEGFR

\section{Introduction}

Receptor tyrosine kinases (RTKs) are ubiquitous cell-surface receptors in mammalian cells, which transduce cellular environment and interaction signals across the plasma membrane to several intracellular signaling networks [1,2]. Receptor tyrosine kinases are divided into 20 subfamilies all sharing similar molecular architecture that consists of an extracellular ligand binding domain, a single transmembrane helix, and a cytoplasmic region composed of a juxta membrane, tyrosine kinase domain (TKD), and a C-terminal tail domain [3]. RTKs are generally activated by receptor-specific ligands (growth factors) through 
receptor dimerization. There are four modes of receptor dimerization which are specific to each RTK family. The first mode is dimerization, completely ligand mediated without any physical interaction between the extracellular regions of the RTKs, e.g., Trka and p73. The second mode is ligand mediated dimerization through physical interaction between receptor as ErbB family members (EGFR,HER2/ErbB2, HER3/ErbB3, and HER4/ErbB4). The third mode of dimerization is mediated by ligand dimers that bind to two receptors and then interact with each other across the dimer interface e.g., SCF/c-KIT. In addition to bivalent ligand binding and receptor physical interaction, the fourth mode of dimerization is mediated by accessory molecules, eg., HGFR, FGFR family [4]. Whether the "inactive" state is monomeric or oligomeric, receptor activation requires binding of growth factor ligands to extracellular regions to induce an "active" state by ligand dependent induced receptor dimerization/oligomerization [4]. For most RTKs, this activation results in conformational changes allowing a trans-autophosphorylation of their tyrosine kinase domain and the release of the cis-autoinhibition conformation [2]. Several studies aimed to understand the consequences of dimerization on the activation procedure, the intracellular conformational switch and signal transduction. As receptor tyrosine kinases are involved in mediating cell-to-cell communication and in controlling several signaling and biological functions, their dysregulation, and consequently, the aberrant activation of their downstream intracellular signaling pathways, lead to many human diseases, such as diabetes, inflammation, severe bone disorders, arteriosclerosis, angiogenesis, and cancer [2]. Genomic studies in almost all types of human tumors show aberrations in several RTKs associated with tumor development and progression such as EGFR, HER2/ErbB2, MET, etc. [4]. RTK dysregulation in different cancers could be led by one of four mechanisms: activating mutation, gene amplification, chromosomal rearrangements, and/or autocrine activation. These observations led to the development of a number of small molecule inhibitors targeting RTKs that were tested in preclinical and clinical studies, and some of them were approved in some tumors associated with RTK dysregulation. Malignant melanoma is one of the most aggressive skin cancers that can disseminate and metastasize from a local site tumor to multiple organs, including lung, liver, brain, bone, and lymph nodes [5]. One of the most significant successful clinical practices in melanoma is the targeted therapies for activating gene driver mutations [6]. For this reason, a melanoma genomic framework was set to help specific therapeutic decisions [7]. Cutaneous melanoma is divided into four genomic subtypes: BRAF, NRAS, NF1, and Triple-WT. Candidate driver events in Triple-WT melanomas include KIT mutations/amplifications and co-amplified RTKs such as PDGFRA and KDR (VEGFR2). BRAF mutation is the most common in melanoma and occurs in 40-60\% of cases [8]. Targeted therapy with BRAF/MEK inhibitors with or without immune check-point inhibitors (ICI) showed significant long-term treatment benefit in BRAF V600-mutated melanoma patients [9]. NRAS-mutation occurs in 15-20\% of melanomas, and the approved ideal treatment for NRAS-mutant melanoma remains unknown, although several combinations of MEK inhibitors with Phosphoinositide 3-kinases (PI3K)-AKT (protein kinase B) pathway inhibitors [10] or CDK4/ 6 inhibition are proposed and under clinical investigation [11]. Recently, new RAS inhibitors targeting different aspects of RAS biochemistry were developed and provide hope that RAS inhibitors will eventually be deployed in the clinic [12]. Patients with KIT-mutant melanoma showed limited response rate to KIT inhibitors and ICI [13]. The latter aberration is most common in mucosal melanoma that most often arises in the oral cavity, nose and paranasal sinuses, genital tract, and anorectal region. Where cutaneous melanoma is common in European population, mucosal melanoma accounts for less than $1 \%$. In other populations such as Asians, cutaneous melanoma is very low, and mucosal melanoma can be as high as $25 \%$ [14]. Mucosal melanoma treatment is arduous, because it is generally detected at a more advanced stage and responds less often to immunotherapy, with a mutational burden lacking MAPK activating mutation as compared to cutaneous melanoma [15]. Commonly to cutaneous melanoma, mucosal mutations shows alterations in SF3B1, KIT, and NF1 and less frequently mutations in BRAF and NRAS [16,17]. 


\section{RTK Activation and Alterations in Melanoma}

In 2017, a large WGS analysis of melanoma reported a frequency of aberrations in RTK pathway of $42 \%$ in acral and mucosal melanoma, which is considerably high [18]. Kinase profiling conducted in a panel of melanoma cell strains showed activation of several receptors including TYRO3, AXL, MERTK, EPHB2, MET, IGF1R, EGFR, KIT, HER3, and HER4 [19]. More importantly, several RTKs were found associated with resistance mechanisms to MAPK inhibition, phenotype switching, metastasis, invasion, and relapses [20,21]. This provided opportunities for preclinical and clinical efforts to effectively target RTKs molecular aberrations. Indeed, several RTK inhibitors were evaluated in preclinical settings and in clinical approaches, but few of the selective/specific inhibitors have been approved for melanoma treatment or are being tested in a specific subset of patients.

Due to the large number of RTKs described and tested in melanoma for different purposes, in this review, we will discuss and compare preclinical to clinical studies in terms of the effect of different RTK inhibitors and their derivatives alone or in combination and the associated resistance mechanisms to the main treatment. We shall also classify the utility of each RTK inhibitor in a specific subset of melanoma patients, treatment regimens, and circumstances of combinations with other treatment modalities.

\section{1. c-KIT (CD117)}

c-KIT, a type III RTK located in a region on the long arm of chromosome 4 (4q11-4q13), encodes the stem cell factor (SCF) receptor (CD117) [22]. The type III class also includes the platelet-derived growth factor (PDGF) receptor ( $\alpha$ - and $\beta$-chains), the macrophage colony-stimulating-factor receptor (CSF-1), and the Fl cytokine receptor (Flt3). Despite that, all RTKs shares the same topology, but what distinguishes the type III is the existence of five immunoglobulin-like domains in the extracellular region of the receptor (Figure 1A). The growth factor binds to the second and third immunoglobulin domains and the fourth domain is involved in receptor dimerization (Figure 1B). The KIT kinase insert domain at which tyrosine phosphorylation occurs and serves as docking site for downstream signal transduction proteins, is about 80 residues in length [23]. Stem cell factor binding to KIT leads to receptor dimerization that is mediated by both ligand homodimer (possibility of heterodimerization is still unknown) and a physical interaction between the two receptors, thus stimulating autophosphorylation in the kinase domain that activates the adaptor protein Grb2 (Tyr703), phosphatidylinositol 3-kinase (Tyr721), and phospholipase C $\gamma$ (Tyr730), leading to the stimulation of protein kinase activity. In addition, other autophoshphorylation in residues in the distal kinase domain can occur that attract other adaptor proteins such Crk (Tyr 900) and APS, Grb2, and Grb7 (Tyr936) [24]. The above listed interactions lead to the activation of several KIT downstream effectors such as AKT, Ras/MAPK, and JAK/STAT [25]. Residues 582-671 cover the small N-terminal lobe of the kinase (anchor and orient ATP), and residues 678-953 make up the large C-terminal lobe (which binds the substrate proteins) with a segment (where lies the KIT catalytic site) between them. The movement of the two lobes is relative to each other, and adopts simultaneous range of orientations, opening or closing the active site cleft) and is mandatory for the kinase activity of KIT. The open form allows ATP access and ADP release from the active site successively, and the closed form brings residues into the catalytically active state [23]. Disruption of this movement is mediated by the juxtamembrane (JM) region (residues 544-581), that favors the inhibition of the kinase activity. Particularly, a phosphorylation of tyrosine residue in the activation loop domain within the large lobe (begins with DFG (810-812) and ends with APE (837-839)) stabilizes the active conformation [23]. To summarize, stem cell factor binding induces RTK dimerization and favors transphosphorylation of two tyrosine residues (568 and 570) in the auto inhibitory JM domain resulting in the movement of the two lobes leading to a conformation conversion of the activation loop domain from a packed to an extended form. 
A

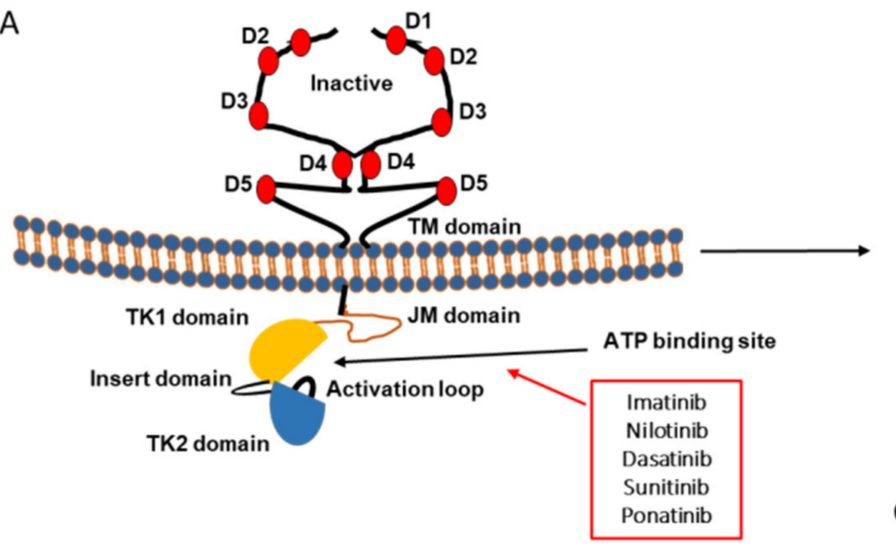

B

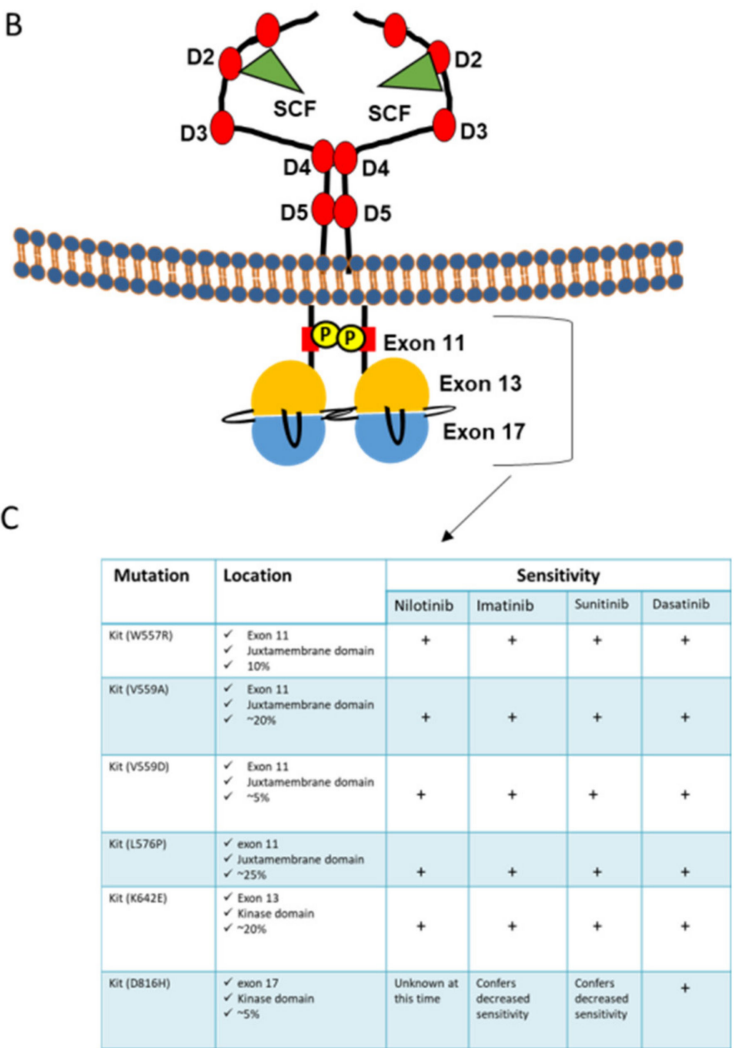

Figure 1. c-KIT structure, activation and mutations in melanoma. (A) The extracellular domain (ECD) of c-KIT consists of five Ig-like domains (D1-D5) followed by a transmembrane domain (TM), juxtamembrane domain (JM), tyrosine kinase 1 domain (TK1), insert domain, tyrosine kinase 2 domain (TK2), and activation loop domain. (B) Ligand homodimers bind to two c-KIT receptors, which interact with each other across the dimer interface. Dimerization mediates conformational changes and transphosphorylation of intracellular tyrosine residues. (C) Locations of most frequent c-KIT mutations in melanoma and its association with variable sensitivity to different RTK inhibitors.

Gain-of-function mutations as well as autocrine or paracrine activation of KIT have been described in several malignancies and may occur in exons that occupy the extracellular, JM, proximal and distal protein kinase domains. Due to distinct functions of receptor domains, all related activating mutations share the same ligand independent receptor activation but not the same structural rearrangement that is of particular importance for therapy. Gain of function mutations of c-KIT can be found in GIST $(>90 \%)$, mast cell tumor $(>70 \%)$ [26] and acute myeloid leukemia ( $>68 \%$ ) [27]. Melanoma Triple-WT subgroup show the highest median KIT protein abundance with enrichment of KIT mutations, focal amplifications and complex structural rearrangements [7]. c-KIT activating mutations allow a ligand-independent activation of the receptor and consequently the constitutive downstream activation of MAPK, PI3K, Janus kinase (JAK)/Signal Transducer, and Activator of Transcription (STAT) [28]. As such, the use of drugs targeting c-KIT has provided a novel approach for cancer treatment. However, several issues have been raised regarding the development of c-KIT inhibitors. KIT mutation occurs in $25 \%$ of acral melanoma, $22 \%$ of mucosal melanoma, and $8 \%$ of cutaneous melanomas. Particularly, $81 \%$ of KIT mutations are distributed between exons 11 and 18 which include L576P, K642E, V559A, and D820Y mutations [29]. However, about $70 \%$ of c-KIT mutations occur in exon 11, with preponderance of L576P that shows poor sensitivity to imatinib in GIST [30], but variable sensitivities in melanoma [31,32]. Several other c-KIT inhibitors, including sunitinib, dasatinib, pexidartinib, sorafenib, ponatinib, and nilotinib, were tested and showed variable activity in c-KIT mutated melanoma as well. As mentioned above, KIT intracellular domains do not share one same function; consequently, activating mutation in juxtamembrane domain 
(exons 11 to 13) results in stabilization of the inactive conformation of the receptor despite its activation. However, an activating mutation in the activating loop domain (exons 17-18) results in continuous activation of the receptor showing stable active conformation. More importantly, RTK inhibitors show different binding affinities and most of them are unable to bind to the active conformation of the receptor, thus resulting in different treatment sensitivities. This is why we will discuss, within the present review, the effect of all c-KIT inhibitors tested in melanoma both in pre-clinical and clinical studies, with a specific focus on their efficacy according to the location of each exon mutation.

\subsubsection{Imatinib (GLEEVEC ${ }^{\circledR}$ )}

Imatinib is a 2-phenyl amino pyrimidine derivative and a potent and selective inhibitor of the protein tyrosine kinase ABL, BCR-ABL, PDGFRA, and c-KIT. The active sites of tyrosine kinases each have a binding site for ATP to favor its enzymatic activity after ligand binding (protein tyrosine phosphorylation). Imatinib, binds close to the ATP binding site, locking it in a closed or self-inhibited conformation thus blocking the enzymatic activity of the protein [33].

As RTKs stand at the apex of cellular signaling and are considered as key transduction molecules, they became targets of interest also for melanoma. Indeed, melanoma cells express c-KIT, PDGF-R, and Abl, and an autocrine growth loop mechanism has been described for the receptor-ligand interaction of PDGF-R/PDGF, as well as for c-KIT/SCF [34]. Consequently, it was suggested that inhibition of RTKs may limit melanoma survival and proliferation. At this time, imatinib mesylate (Glivec ${ }^{\circledR}$, formerly STI571, Novartis, Basel, Switzerland), used with success in CML [35] and GIST [36], has been used in a mouse melanoma model. Despite an efficient inhibition of PDGF-R phosphorylation within the tumor, no effect was observed on its growth (Table 1) [37]. Conversely, another study reported growth inhibition of B16F10 mouse melanoma cells in vitro and in vivo (Table 1) [38], but this did not translate clinically, and no objective responses were observed with imatinib in advanced metastatic melanoma based on the relative expression densities of receptor tyrosine kinases c-KIT and PDGF-R (Table 2) [39]. As imatinib showed remarkable effective clinical responses in several cancers [36,40], and as the expression of its targets (c-KIT, PDGFR) has been validated in melanoma, it was also tested in phase II trial but showed limited clinical responses as a single agent, even in tumors with high PTKs expression (Table 2) [41]. It was concluded that its clinical success may depend on a more precise selection of patients with exploitable tumor targets or in combination with other agents (Table 2) [42]. In 2006, Curtin JA et al. reported KIT as an important oncogene in melanoma and proposed that imatinib can be beneficial in this significant group of patient [43]. Consequently, several in vitro studies focused on assessment of imatinib in c-KIt mutant melanoma and reported significant sensitivities (Table 1) [44]. Coherently, the NCT00470470 clinical trial showed significant clinical responses of imatinib in a subset of patients harboring KIT alterations with overall response rate of $16 \%(95 \%$ CI, 2-30\%) (Table 2) [31]. In parallel, a phase II trial with imatinib in China demonstrated overall response rate to imatinib of 30.2\% (95\% CI, 16-44.4) (Table 2) [45]. In accordance, the NCT00424515 trial indicated that imatinib was effective only in tumors harboring KIT mutations, and not KIT amplification and one of the mechanisms of resistance to imatinib could be associated to NRAS mutations or KIT copy number gain (Table 2) [32]. Furthermore, a diversity of KIT mutations was shown in melanoma, some were sensitive to imatinib, while others were either imatinib-resistant or not studied yet. Particularly, it was reported that melanoma non-responders harbor specific c-KIT mutations known to confer imatinib resistance in GIST, such as D820Y, N822K, and A829P, while responders show mutation on exon 11 or exon 13 [31,32]. In 2014, a case report expanded the melanoma population that could benefit from imatinib to those with somatic exon 8 KIT mutations [46].

Based on these studies, exon locations of KIT mutation as well as the ratio of mutant to wild-type KIT alleles were considered as predictive markers for clinical response to imatinib. Particularly, L576P or K642E mutation were associated with better clinical outcomes 
compared to those with a V654A or D820Y mutation already reported with resistance to imatinib in GIST. Taken together, the identification of KIT mutation is mandatory for selection of patients that could benefit from imatinib [47].

As imatinib was tested in phase II trials in melanoma with no significant long-term responses due to intrinsic or acquired resistance, several combination strategies were proposed. A phase I/II trial tested the safety and efficacy of imatinib in combination with bevacizumab (highly selective VEGF-A, the isoform that binds VEGF receptor (VEGFR) 1 and VEGFR2) in patients with advanced melanoma to prevent angiogenesis. The combination was well tolerated but did not improve clinical response (Table 2) [48]. Of interest, imatinib was reported to inhibit immunosuppressive mechanisms and to favor antigenpresenting cells function [49]. Accordingly, it was predicted that imatinib could be a promising candidate to synergistically enhance antitumor T-cell activation provided by CTLA-4 blockade immunotherapy [50] but showed response in one KIT-mutated melanoma patient and further investigation are still ongoing (Table 2) [50]. A Phase I/II study to evaluate the safety and efficacy of the combination imatinib with temozolomide in patients with unresectable, stage III/IV melanomas was launched and reported a complete response in one of seven patients and progression in the remaining. No further informations was reported later about this combination [51]. In 2016, a clinical trial was set up in order to evaluate the clinical benefit of combining pembrolizumab and imatinib in patients with locally advanced/metastatic melanoma harboring c-KIT Mutation/Amplification (NCT02812693), but unfortunately, the trial was withdrawn due to poor accrual [52]. Interestingly, a case report in 2019 showed a good control of the disease over two years with the combination after the failure of anti-PD-1 monotherapy in a patient with double KIT mutations (V559 and N822I). This combination was associated with increased manageable toxicity and tumor control before progression [53]. Recent evidence, from retrospective studies published in 2019, indicates the efficacy and safety of imatinib compared to other RTKi tested in melanoma with an overall response rate (ORR) of $21.8 \%$, in addition to an ongoing open clinical trial with estimated completion year in 2022 (Table 2) [54].

Table 1. Summary of the effect of different KIT inhibitors evaluated in melanoma preclinical studies.

\begin{tabular}{|c|c|c|c|}
\hline RTKi & Cell Lines Used & Results & Reference \\
\hline Imatinib & $\begin{array}{l}\text { A } 375 \mathrm{SM} \text { (from pooled lung metastases by } \\
\left.\text { A375 cells ( }{ }^{\mathrm{V} 600 \mathrm{E}} \mathrm{BRAF}\right), \text { intravenously } \\
\text { injected to nude mice } \\
\left.\text { MeWo cells ( }{ }^{\mathrm{WT}} \mathrm{BRAF},{ }^{\mathrm{WT}} \mathrm{NRAS}\right) \\
\text { injected into nude mice }\end{array}$ & $\begin{array}{l}\text {-Imatinib did not affect A375SM and MeWo } \\
\text { growth in vivo but inhibits PDGFR- } \alpha \text { and } \\
\text { PDGFR- } \beta \text { phosphorylation in A375SM } \\
\text { xenografts. }\end{array}$ & McGary, E.C., et al. 2004 [37] \\
\hline Imatinib & $\begin{array}{l}\text { B16F10 murine melanoma cells in C57B16 } \\
\text { mice }\end{array}$ & $\begin{array}{l}\text {-Imatinib inhibits B16F10 melanoma cell } \\
\text { proliferation and growth in a mouse model. }\end{array}$ & Redondo, P., et al. 2004 [38] \\
\hline Imatinib & 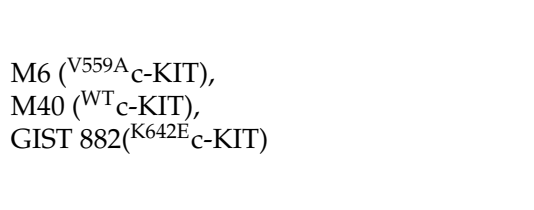 & $\begin{array}{l}\text {-Imatinib inhibits cell proliferation, MAPK, } \\
\text { P3K/AKT, STAT pathways, favors G1 arrest, } \\
\text { enhances apoptosis, and reduces cyclin D1, in } \\
\text { M6 and GIST } 882 \text { cells. } \\
\text {-Imatinib reduces BCL-2, MCL-1, ML-IAP, and } \\
\text { survivin in both M6 and GIST882 cells. }\end{array}$ & Jiang, X., et al. 2008 [44] \\
\hline $\begin{array}{l}\text { Imatinib / } \\
\text { nilotinib }\end{array}$ & $\begin{array}{l}\left.\text { SKMel28 ( }{ }^{\mathrm{V} 600 \mathrm{E}} \mathrm{BRAF}\right) \\
\text { M230 ( } 576 \mathrm{P}_{\text {C-KIT), }} \\
\text { IMR_A829P (imatinib-resistant clone) } \\
\text { NR T670I (nilotinib-resistant clone) }\end{array}$ & $\begin{array}{l}\text {-M230 but not SKMel } 28 \text { melanoma cells are } \\
\text { sensitive to imatinib and nilotinib. } \\
\text {-Drug-resistant clones exhibit secondary c-KIT } \\
\text { mutations and retain c-KIT activation even in } \\
\text { the presence of inhibitors. } \\
\text {-IMR_A829P cells retains a strong apoptotic } \\
\text { response } \\
\text { to nilotinib and dasatinib. } \\
\text {-NR_T670I cells undergo significant apoptosis } \\
\text { in response to sunitinib. }\end{array}$ & Todd, J.R., et al. 2013 [55] \\
\hline
\end{tabular}


Table 1. Cont.

\begin{tabular}{|c|c|c|c|}
\hline RTKi & Cell Lines Used & Results & Reference \\
\hline Nilotinib & M230 ( ${ }^{\left.\mathrm{L} 576 \mathrm{P}_{\mathrm{C}}-\mathrm{KIT}\right)}$ & $\begin{array}{l}\text {-Nilotinib inhibits cell proliferation and } \\
\text { reduces STAT3 signaling. }\end{array}$ & Delyon, J., et al. 2018 [56] \\
\hline Dasatinib & $\begin{array}{l}\left.\text { Lox-IMVI ( }{ }^{\mathrm{V} 600 \mathrm{E}} \mathrm{BRAF}\right), \\
\left.\text { Malme-3M ( }{ }^{\mathrm{V} 600 \mathrm{E}} \mathrm{BRAF}\right), \\
\left.\text { Sk-Mel-5 ( }{ }^{\mathrm{V} 600 \mathrm{E}} \mathrm{BRAF}\right), \\
\left.\text { Sk-Mel-28 ( }{ }^{\mathrm{V} 600 \mathrm{E}} \mathrm{BRAF}\right) \\
\left.\text { and HT144 ( }{ }^{\mathrm{V} 600 \mathrm{E}} \text { BRAF }\right)\end{array}$ & $\begin{array}{l}\text {-Dasatinib inhibits growth of Lox-IMVI, } \\
\text { Malme-3M, HT144, cell migration and } \\
\text { invasion in HT144 and Sk-Mel-28. } \\
\text {-Dasatinib increases apoptosis in Lox-IMVI, } \\
\text { Malme-3M, favors G1 arrest in Lox-IMVI and } \\
\text { HT144 and enhances response to } \\
\text { temozolomide in HT144, Malme-3M and } \\
\text { Lox-IMVI. }\end{array}$ & Eustace, A.J., et al. 2008 [57] \\
\hline Dasatinib & $\begin{array}{l}\text { MeWo }\left({ }^{\mathrm{WT}} \mathrm{BRAF},{ }^{\mathrm{WT}} \mathrm{NRAS}\right), \\
\text { SK-Mel-5 }\left({ }^{\mathrm{V} 600 \mathrm{E}} \mathrm{BRAF}\right), \\
\text { SK-Mel-28 }\left({ }^{\mathrm{V} 600 \mathrm{E}} \mathrm{BRAF}\right), \\
\left.\text { A375 ( }{ }^{\mathrm{V} 600 \mathrm{E}} \text { BRAF), A2058 ( }{ }^{\mathrm{V} 600 \mathrm{E}} \mathrm{BRAF}\right), \\
\left.\text { G361( }{ }^{\mathrm{V} 599 \mathrm{E}} \mathrm{BRAF}\right), \\
\left.\text { 1205-Lu ( }{ }^{\mathrm{V} 600 \mathrm{E}} \mathrm{BRAF}\right) \\
\left.\text { 451-Lu cells ( }{ }^{\mathrm{V} 600 \mathrm{E}} \mathrm{BRAF}\right)\end{array}$ & $\begin{array}{l}\text {-Dasatinib inhibits migration and invasion in } \\
\text { 1205-Lu and A2058 cell lines. } \\
\text {-Dasatinib decreases MMP9, inhibits EphA2 } \\
\text { kinase activity and blocks SFK in A2058 cells. }\end{array}$ & Buettner, R., et al. 2008 [58] \\
\hline Dasatinib & $\begin{array}{l}\text { WM3211 ( }{ }^{\left.\mathrm{L} 576 \mathrm{P}_{\mathrm{C}}-\mathrm{KIT}\right)}, \\
\left.\text { A375 ( }{ }^{\mathrm{V} 600 \mathrm{E}} \mathrm{BRAF}\right) \\
\text { MeWo }\left({ }^{\mathrm{WT}} \mathrm{BRAF},{ }^{\mathrm{WT}} \mathrm{NRAS}\right)\end{array}$ & $\begin{array}{l}\text {-L576P mutation induces structural changes in } \\
\text { KIT that reduce imatinib affinity. } \\
\text {-Dasatinib alone reduces cell viability of the } \\
\text { L576P mutant cell line. }\end{array}$ & $\begin{array}{l}\text { Woodman, S.E., et al. } 2009 \\
\text { [59] }\end{array}$ \\
\hline Dasatinib & $\begin{array}{l}\left.\text { A375( }{ }^{\mathrm{V} 600 \mathrm{E}} \mathrm{BRAF}\right) \\
\left.\text { Sk-Mel-5 ( }{ }^{\mathrm{V} 600 \mathrm{E}} \mathrm{BRAF}\right) \\
\left.\text { Sk-Mel-28 ( }{ }^{\mathrm{V} 600 \mathrm{E}} \text { BRAF }\right)\end{array}$ & $\begin{array}{l}\text {-Dasatinib inhibits growth of melanoma cell } \\
\text { lines and synergized with cisplatin }\end{array}$ & Homsi, J., et al., 2009 [60] \\
\hline Dasatinib & $\begin{array}{l}\text { Mel-p (primary melanoma), } \\
\text { A375 ( }{ }^{\text {V600E }} \text { BRAF, Q61K NRAS) }\end{array}$ & $\begin{array}{l}\text {-Dasatinib leads to growth inhibition of Mel-p. } \\
\text {-Dasatinib induces cell differentiation, } \\
\text { remodels the actin cytoskeleton, and inhibits } \\
\text { nuclear translocation of ERK1/2 }\end{array}$ & Wu, J., et al. 2013 [61] \\
\hline Dasatinib & $\begin{array}{l}\left.\text { Lox-IMVI ( }{ }^{\mathrm{V} 600 \mathrm{E}} \mathrm{BRAF}\right), \\
\left.\text { Malme-3M ( }{ }^{\mathrm{V} 600 \mathrm{E}} \mathrm{BRAF}\right), \mathrm{M} 14\left({ }^{\mathrm{V} 600 \mathrm{E}} \mathrm{BRAF}\right), \\
\left.\text { Sk-Mel-5 ( }{ }^{\mathrm{V} 600 \mathrm{E}} \mathrm{BRAF}\right), \\
\left.\text { Sk-Mel-28 ( }{ }^{\mathrm{V} 600 \mathrm{E}} \mathrm{BRAF}\right)\end{array}$ & $\begin{array}{l}\text {-Lox-IMV, WM-115 and HT144 cells showed } \\
\text { sensitivity to dasatinib. } \\
\text {-Malme-3M, WM266-4, M14, Sk-Mel-28 and } \\
\text { Sk-Mel-5 cells were resistant to dasatinib. } \\
\text {-High protein expression of ANXA1, CAV-1 or } \\
\text { EphA2 in the sensitive melanoma cells that } \\
\text { predicts sensitivity to dasatinib }\end{array}$ & Eustace, A.J., et al. 2014 [62] \\
\hline Dasatinib & 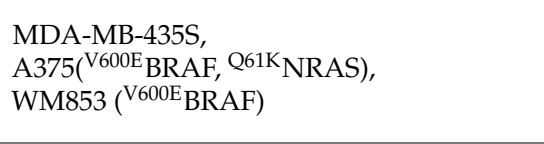 & $\begin{array}{l}\text {-SIRT2 silencing renders melanoma cells more } \\
\text { sensitive to dasatinib. } \\
\text {-SIRT2 loss enhances dasatinib effect on cell } \\
\text { migration inhibition and cell cycle arrest. }\end{array}$ & Karwaciak, I., et al. 2019 [63] \\
\hline Sunitinib & $\begin{array}{l}\text { A-07 and R-18 human melanoma cells } \\
\text { transfected with GFP in female BALB/c } \\
\text { nu/nu mice }\end{array}$ & $\begin{array}{l}\text {-Sunitinib increases hypoxia, vessel segment } \\
\text { length, and median vessel diameter, does not } \\
\text { affect blood supply time (BST), vascular } \\
\text { basement membrane, vessel tortuosity and } \\
\text { pericyte-coverage but reduces vessel density. } \\
\text {-Prolonged exposure, reduces tumor growth. }\end{array}$ & Gaustad, J.-V., et al. 2012 [64] \\
\hline Sunitinib & $\begin{array}{l}\text { Amelanotic human melanoma A-07 in } \\
\text { female BALB/c-nu/nu mice }\end{array}$ & $\begin{array}{l}\text {-Sunitinib treatment does not affect tumor } \\
\text { growth but increases microvascular density } \\
\text { (MVD), hypoxia, necrosis, and ADC, but } \\
\text { reduces K trans. }\end{array}$ & Gaustad, J.-V., et al. 2013 [65] \\
\hline Ponatinib & $\begin{array}{l}\mathrm{KIT}^{\mathrm{WT}} \\
\mathrm{KIT}^{\mathrm{V} 560 \mathrm{D}} \\
\mathrm{KIT}^{\mathrm{K} 642 \mathrm{E}}{ }^{\prime} \\
\mathrm{KIT}^{\mathrm{D} 816 \mathrm{~V}^{\prime}} \text { PDX mice }\end{array}$ & $\begin{array}{l}\text {-Ponatinib reduces cell viability, KIT, AKT, } \\
\text { ERK phosphorylation, cell proliferation, tumor } \\
\text { growth and induces apoptosis in the KIT } \\
\text { mutant PDX in vitro and in vivo with high } \\
\text { affinity to KITD816V. }\end{array}$ & Han, Y., et al. 2019 [66] \\
\hline
\end{tabular}


Table 2. Effect of imatinib alone or in combination in melanoma clinical trials.

\begin{tabular}{|c|c|c|c|c|c|c|c|}
\hline RTKi & $\begin{array}{l}\text { Phase/Year } \\
\text { Published or } \\
\text { Presented }\end{array}$ & Population & $N$ & Dose & Survival & Response & Adverse Reactions \\
\hline Imatinib & $\begin{array}{c}\text { Phase II, } \\
\text { Ugurel, S., et al. } \\
2005 \text { [39] }\end{array}$ & $\begin{array}{l}\text { Median age of } \\
54.2 \text { years } \\
\text { (range, } \\
38.9-72.0) \\
\text { years }\end{array}$ & 18 & $800 \mathrm{mg} /$ day & $\begin{array}{l}\text { Median OS and } \\
\text { PFS = } 3.9 \text { and } 1.9 \\
\text { months, } \\
\text { respectively }\end{array}$ & $\begin{array}{l}\text { No objective } \\
\text { responses }\end{array}$ & $\begin{array}{l}\text { Severe (AE)s of grade } 3 \\
\text { and 4: Exanthema, } \\
\text { Constipation, intestinal } \\
\text { perforation, arterial } \\
\text { thromboembolism, } \\
\text { suicide attempt }\end{array}$ \\
\hline Imatinib & $\begin{array}{c}\text { Phase II, } \\
\text { Wyman, K., } \\
\text { et al. 2006 [41] }\end{array}$ & $\begin{array}{l}\text { Median age of } \\
59 \text { years (range, } \\
37-82 \text { ) years }\end{array}$ & 26 & $800 \mathrm{mg} /$ day & $\begin{array}{l}\text { Median OS and } \\
\text { PFS = } 6.5 \text { and two } \\
\text { months } \\
\text { respectively }\end{array}$ & $\begin{array}{l}\text { No objective } \\
\text { responses }\end{array}$ & $\begin{array}{c}\text { Grade } 3 \text { and grade } 4 \\
\text { toxicity: } \\
\text { Gastrointestinal } \\
\text { toxicities, nausea and } \\
\text { emesis }\end{array}$ \\
\hline Imatinib & $\begin{array}{l}\text { Phase II, Kim, } \\
\text { K.B., et al. } 2008 \\
\text { [42] }\end{array}$ & $\begin{array}{l}\text { Median age of } \\
58 \text { years (range, } \\
\text { 33-83) years }\end{array}$ & 21 & $\begin{array}{l}400 \underset{\text { daily) }}{\mathrm{mg} \text { (twice }} \\
\text { d }\end{array}$ & $\begin{array}{c}\text { Median OS and } \\
\text { PFS }=7.5 \text { and } 1.4 \\
\text { months } \\
\text { respectively }\end{array}$ & $\begin{array}{l}4 \text { SD and } \\
1 \text { PR }\end{array}$ & $\begin{array}{l}\text { Common toxicity of } \\
\text { grade } 3 \text { or } 4: \text { Fatigue } \\
\text { and oedema }\end{array}$ \\
\hline Imatinib & $\begin{array}{c}\text { Phase II, } \\
\text { Carvajal, R.D., } \\
\text { et al. } 2011 \text { [31] }\end{array}$ & $\begin{array}{l}\text { Median age of } \\
71 \text { (range, } \\
49-88 \text { ) years }\end{array}$ & 28 & $\begin{array}{l}400 \mathrm{mg} \text { (twice } \\
\text { daily) }\end{array}$ & $\begin{array}{l}\text { Median OS and } \\
\text { PFS = } 10.7 \text { and } 2.8 \\
\text { months, } \\
\text { respectively }\end{array}$ & $\begin{array}{c}2 \mathrm{CRs}, 2 \text { PRs, } 2 \\
\text { transient PRs, } \\
\text { and } 5 \text { SD }\end{array}$ & \\
\hline Imatinib & $\begin{array}{l}\text { Phase II trial, } \\
\text { Guo, J., et al. } \\
2011 \text { [45] }\end{array}$ & $\begin{array}{l}\text { Median age of } \\
57 \text { (range, } \\
27-76) \text { years }\end{array}$ & 43 & $400 \mathrm{mg} / \mathrm{d}$ & $\begin{array}{l}\text { Median OS and } \\
\text { PFS = } 15 \text { and } 9 \\
\text { months, } \\
\text { respectively. }\end{array}$ & $\begin{array}{l}10 \text { PRs, } 13 \mathrm{SD} \\
\text { and } 18 \text { showed } \\
\text { tumor } \\
\text { regression }\end{array}$ & $\begin{array}{c}\text { Common AEs: edema, } \\
\text { fatigue, anorexia, } \\
\text { nausea, neutropenia, } \\
\text { elevated AST ALT }\end{array}$ \\
\hline Imatinib & $\begin{array}{l}\text { Phase II trial, } \\
\text { Hodi, F.S., et al. } \\
2013 \text { [32] }\end{array}$ & $\begin{array}{l}\text { Median age of } \\
65 \text { (range, } \\
42-84 \text { ) years }\end{array}$ & 25 & $400 \mathrm{mg} /$ day & $\begin{array}{c}\text { Median OS and } \\
\text { TTP = } 12.5 \text { and } 3.7 \\
\text { months, } \\
\text { respectively }\end{array}$ & $\begin{array}{l}7 \text { patients } \\
\text { achieved CRs } \\
\text { or PRs }\end{array}$ & $\begin{array}{c}\text { The common reported } \\
\text { (AE)s: nausea, fatigue, } \\
\text { anemia, hyperglycemia, } \\
\text { and vomiting }\end{array}$ \\
\hline $\begin{array}{l}\text { Imatinib + } \\
\text { Beva- } \\
\text { cizumab } \\
\text { (Bevax) }\end{array}$ & $\begin{array}{l}\text { Phase I/II trial, } \\
\text { Flaherty, K., } \\
\text { et al. } 2015 \text { [48] }\end{array}$ & $\begin{array}{l}\text { Median age of } \\
63 \text { (range, } \\
49-86) \text { years }\end{array}$ & 23 & $\begin{array}{c}\text { Bevax } 10 \\
\mathrm{mg} / \mathrm{kg}+ \\
\text { imatinib } 400 \text { or } \\
600 \text { or twice } \\
800 \mathrm{mg}\end{array}$ & $\begin{array}{c}\text { The median PFS = } \\
7.7 \text { weeks }\end{array}$ & $\begin{array}{c}\text { A PR was } \\
\text { observed in } 1 \\
\text { patient and } 7 \\
\text { showed SD }\end{array}$ & $\begin{array}{l}\text { Common toxicities: } \\
\text { fatigue, nausea, } \\
\text { vomiting, edema, } \\
\text { proteinuria, and } \\
\text { anemia, but were not } \\
\text { commonly severe }\end{array}$ \\
\hline $\begin{array}{l}\text { Imatinib + } \\
\text { Ipili- } \\
\text { mumab } \\
\text { (IPI) }\end{array}$ & $\begin{array}{l}\text { Phase I Reilley, } \\
\text { M.J., et al. } 2017 \\
\text { [50] }\end{array}$ & $\begin{array}{l}\text { Median age of } \\
55 \text { years, } \\
\text { showing KIT } \\
\text { positive } \\
\text { tumour }\end{array}$ & 7 & $\begin{array}{c}400 \mathrm{mg} \\
\text { imatinib (one } \\
\text { or twice daily) } \\
+\mathrm{IPI} 1 \\
\mathrm{mg} / \mathrm{kg} / 3 \\
\mathrm{mg} / \mathrm{kg} \text { ) on day } \\
1 \text { of each } 21 \\
\text { day } / \text { cycle }\end{array}$ & & $\begin{array}{l}\text { One partial } \\
\text { response } \\
\text { observed in } \\
\text { one KIT } \\
\text {-mutated } \\
\text { melanoma } \\
\text { patient }\end{array}$ & $\begin{array}{l}\text { The common (AE)s } \\
\text { were fatigue, nausea, } \\
\text { vomiting, anorexia, } \\
\text { anemia, edema, } \\
\text { diarrhea, rash, } \\
\text { shortness of breath, } \\
\text { constipation, } \\
\text { neuropathy, } \\
\text { thrombocytopenia, and } \\
\text { infection }\end{array}$ \\
\hline Imatinib & $\begin{array}{l}\text { Retrospective } \\
\text { study, Wei, X., } \\
\text { et al. } 2019 \text { [54] }\end{array}$ & $\begin{array}{l}\text { Median age of } \\
54 \text { (range, } \\
\text { 11-80) with } \\
\text { c-KIT } \\
\text { alterations }\end{array}$ & 78 & $400 \mathrm{mg} /$ day & $\begin{array}{l}\text { Median OS and } \\
\text { PFS = } 13.1 \text { and } 4.2 \\
\text { months } \\
\text { respectively }\end{array}$ & $\begin{array}{l}2 \text { patients were } \\
\text { alive without } \\
\text { disease } \\
\text { progression }\end{array}$ & $\begin{array}{c}\text { The common (AE)s } \\
\text { were: edema, rash, } \\
\text { fatigue, anorexia, } \\
\text { nausea, and } \\
\text { neutropenia. Vomiting, } \\
\text { psychiatric symptoms, } \\
\text { and elevated ALT or } \\
\text { AST, in a fraction of } \\
\text { patients }\end{array}$ \\
\hline
\end{tabular}

Abbreviations: AE: adverse event; CR: complete response; OS: overall survival; PD: progressive disease; PFS: progression free survival; PR: partial response; SD: stable disease; TTP: time to progression.

\subsection{Nilotinib (TASIGNA $\left.{ }^{\circledR}\right)$}

Since it has become evident that some c-KIT mutant melanoma patients do benefit from imatinib, but develop resistance, and others show intrinsic/innate resistance to the drug related to exon mutation position on c-KIT, a second-generation of tyrosine kinase inhibitors have been introduced, including nilotinib. Nilotinib binds to the kinase domain 
of ABL/BCR-ABL,DDR, KIT, PDGF, and several EPH receptor kinases and maintains potency against a range of exon 9,11 , and 13 KIT mutations [67]. Nilotinib is a type II inhibitor; it binds to lipophilic ATP pocket, with a 30-fold higher potency than imatinib. Preliminary clinical results, showed a promising and durable response, with nilotinib in c-KIT metastatic melanoma patients showing mutation in exon 11, but nilotinib antitumor activity in melanoma patients with KIT amplification was not clear at this time (Table 3) [68]. In 2013, Todd et al. reported that secondary c-KIT mutations can confer acquired resistance to imatinib and nilotinib in c-KIT mutant melanoma cells (M230 c-Kit L576P) and suggested alternative RTK inhibitors or inhibitors targeting the MAPK and PI3K signaling cascades to overcome resistance (Table 1) [55]. Unfortunately, these results were not observed clinically and none of c-KIT mutant melanoma patients developed secondary c-KIT mutation following treatment with imatinib or nilotinib [69]. Particularly, in 2015, a phase II trial with nilotinib in c-KIT melanoma was launched for patients who experienced disease progression, innate resistance to a prior KIT inhibitor, and a cohort of patients with brain metastases. The first results showed clinical benefit of nilotinib in some patients with melanoma harboring KIT alterations previously treated with KIT inhibitor (imatinib) but its efficacy in brain metastases was limited and needs further investigation (Table 3) [69]. In accordance, a phase 2 clinical trial of nilotinib in Korea for KIT mutant/amplified melanoma patients (UN10-06) indicates the safety and efficacy of nilotinib without showing any outperformance over imatinib effect in terms of progression free and overall survival (Table 3) [70]. Particularly, among the seven responders, five showed KIT mutations on exon 11,1 patient showed mutation on exon 17 and 1 had KIT amplification (Table 3) [70]. In 2017, end-point clinical trial indicates that nilotinib could be an additional treatment option for KIT-mutated advanced patients or for intolerant patients to imatinib and in contrast to what have been observed in CML patients, nilotinib did not show any better response compared to imatinib and further proposed to investigate the potential role of combining c-KIT inhibitor to immunotherapy as a next step (Table 3) [71]. One case report in 2017, underlined the benefit of imatinib in a patient showing c-KIT tumor progression following treatment with niltoinib and ipilimumab [72]. In accordance with previous reports on imatinib and nilotinib, a phase 2 clinical trial in the French Skin Cancer Network showed that response to nilotinib is restricted to patients harboring exon 11 or 13 mutations, in addition to other factors that could be taken into consideration, such as high expression of PDGFR, BCL-2, and MCL-1 but low cyclin-D1 (Tables 1 and 3) [56]. In addition, the authors bring evidence of STAT3 pathway inhibition in nilotinib responders and provide a rationale for future research assessing STAT inhibitors in the treatment of KIT-mutated melanomas [56].

\subsection{Dasatinib (Sprycel ${ }^{\circledR}$ )}

Dasatinib is an orally available, multi-kinase inhibitor targeting BCR-ABL tyrosine kinase receptor, SRC, c-KIT and ephrin receptors. Dasatinib received FDA approval in 2006 [73]. As at this time, Src and Yes were detected up-regulated in melanoma compared to normal melanocytes and dasatinib showed promising preclinical outcomes in breast, pancreatic, and colon cancer, it was tested for its efficiency in melanoma. In 2008, Eustace et al. showed that Src inhibition by dasatinib induces growth impairment, inhibits invasion/migration, favors apoptosis/G1 arrest, and enhances response to chemotherapy (temozolomide) in melanoma lines (Table 1) [57]. Dasatinib was also reported for its capacity to inhibit EphA2, Src family kinase particularly, FAK and Crk-associated substrate that consequently abolishes migration and invasion without any significant effect on melanoma cell viability or proliferation (Table 1) [58]. In contrast, it was shown that dasatinib, as Src inhibitor, impaired growth of melanoma cell lines and synergized with cisplatin but not with temozolomide or paclitaxel (Table 1) [60]. Moreover, a combination of dasatinib and dacarbazine was tested and showed its safety $(70 \mathrm{mg}$ dasatinib PO b.i.d with dacarbazine $800 \mathrm{mg} \cdot \mathrm{m}^{-2}$ ) with clinical benefit in seven out of $11(54.5 \%)$ patients (Table 4) [74]. Additionally, Woodman et al. in 2009 characterized the first cell line with L576P c-KIT 
mutation, the most frequent c-Kit mutation in melanoma. Surprisingly, this cell line showed resistance to imatinib but sensitivity to dasatinib due to receptor conformational change related to L576P mutation that affected imatinib-KIT binding ability (Table 1) [59]. Furthermore, the first phase 2 clinical trial of dasatinib in melanoma showed minimal clinical outcome in advanced unselected melanoma patients, indicating the importance of identifying predictive biomarkers for future use of dasatinib alone or in combination [75]. Nevertheless, a preclinical study conducted in 2013 indicated that dasatinib can impair growth, proliferation and induce morphological differentiation in only primary melanoma cells attributed to its ability to suppress activated ERK nuclear translocation (Table 1) [61]. In 2014 and due to the variable response to dasatinib reported in preclinical and clinical studies, Eustace et al. tried to identify predictive biomarkers and could identify a group of melanoma with high SRC, ANXA1, CAV-1, and EphA2 expression, which are more likely to benefit from dasatinib (Table 1) [62]. Furthermore, and based on preclinical studies indicating superior activity of dasatinib among other RTKi to the most common mutation on exon $11^{\text {L576P }}$ KIT, a phase II Trial (E2607) assessed dasatinib in KIT positive melanoma patients but the trial closed early because of slow accrual and too modest responses. It was concluded that due to its efficacy and limited toxicity, imatinib remains the treatment of choice for patients with unresectable KIT+ melanoma (Table 4) [76]. However, the discrepancy between the favorable effects of dasatinib in preclinical and the seldom efficacy in some patients highlights the need for reliable biomarkers to predict response in melanoma. Accordingly, preclinical studies published in 2018 indicates that dasatinib and dacarbazine combination was not synergistic, but put forward that the level of phosphorylated p53 (S46) significantly decreased in dasatinib-responsive cell lines attributed to an effect on its target p38 MAPK, which phosphorylates p53 at S46 and thus favors p53 function as an apoptosis inducer. The study concluded that investigating dasatinib responsiveness markers is of importance when considering future clinical trials evaluating dasatinib and DNA genotoxic drugs combinations to promote p53-dependent apoptosis (Table 1) [77]. Recently, SIRT2 was identified as important regulator of melanoma cells functions, such as cell motility, proliferation, and particularly resistance to dasatinib in melanoma (Table 1) [63].

Table 3. Nilotinib monotherapy in melanoma clinical trials.

\begin{tabular}{|c|c|c|c|c|c|c|c|}
\hline RTKi & $\begin{array}{l}\text { Phase/Year } \\
\text { Published or } \\
\text { Presented }\end{array}$ & Population & $N$ & Dose & Survival & Response & Adverse Reactions \\
\hline Nilotinib & $\begin{array}{c}\text { Phase II, Cho, } \\
\text { J.H., et al. } 2012 \\
\text { [68] }\end{array}$ & $\begin{array}{c}\text { Median age } 51 \text { (range, } \\
\text { 37-68) }\end{array}$ & 11 & $\begin{array}{l}400 \underset{\text { mg twice }}{\text { daily }} \\
\text { al }\end{array}$ & $\begin{array}{c}\text { Median OS and } \\
\text { PFS = } 7.7 \text { and } 2.5 \\
\text { months, } \\
\text { respectively }\end{array}$ & 2 PRs and $5 \mathrm{SD}$ & $\begin{array}{l}\text { Common AEs: alopecia, skin } \\
\text { rash and headache }\end{array}$ \\
\hline Nilotinib & $\begin{array}{l}\text { Phase II, } \\
\text { Carvajal, R.D., } \\
\text { et al. 2015 [69] }\end{array}$ & $\begin{array}{l}\text { Median age of } 67 \\
\text { years (range, } 38-85 \\
\text { years) in } 2 \text { cohorts: } \\
\text { (A) refractory/shows } \\
\text { resistance to a prior } \\
\text { KIT inhibitor; (B) } \\
\text { patients with brain } \\
\text { metastases }\end{array}$ & 19 & $\begin{array}{l}400 \text { mg twice } \\
\text { daily }\end{array}$ & $\begin{array}{l}\text { Median OS =9.1 } \\
\text { months and TTP } \\
\quad=3.3 \text { months }\end{array}$ & $\begin{array}{l}\text { In Cohort A, } 2 \\
\text { patients } \\
\text { achieved PRs } \\
\text { and none } \\
\text { observed in } \\
\text { cohort B }\end{array}$ & $\begin{array}{l}\text { Toxicity rates and patterns } \\
\text { were similar for Cohorts A } \\
\text { and B. The Common AEs: } \\
\text { fatigue, low-grade } \\
\text { musculoskeletal, } \\
\text { gastrointestinal discomfort. }\end{array}$ \\
\hline Nilotinib & $\begin{array}{l}\text { Phase II, Lee, S.J., } \\
\text { et al. } 2015 \text { [70] }\end{array}$ & $\begin{array}{l}\text { Median age of } 56 \\
\text { (range, 28-81) years }\end{array}$ & 42 & $\begin{array}{l}400 \text { mg twice } \\
\text { daily }\end{array}$ & $\begin{array}{c}\text { Median OS and } \\
\text { PFS = } 74 \text { and } 34 \\
\text { weeks, } \\
\text { respectively }\end{array}$ & $1 \mathrm{CR}$ and $6 \mathrm{PRs}$ & $\begin{array}{l}\text { Most common AEs: anemia, } \\
\text { skin rash, liver enzyme } \\
\text { elevation, jaundice, anorexia, } \\
\text { fatigue, and nausea. }\end{array}$ \\
\hline Nilotinib & $\begin{array}{l}\text { Phase II, Guo, J., } \\
\text { et al. } 2017 \text { [71] }\end{array}$ & $\begin{array}{l}\text { Median age } 65.5 \\
\text { (range, 20-87) years }\end{array}$ & 42 & $\begin{array}{l}400 \text { mg twice } \\
\text { daily }\end{array}$ & $\begin{array}{l}\text { Median OS and } \\
\text { PFS }=18 \text { and } 4.2 \\
\text { months, } \\
\text { respectively }\end{array}$ & 3 PRs & $\begin{array}{c}\text { Rash, increased blood } \\
\text { bilirubin, nausea, decreased } \\
\text { appetite fatigue }\end{array}$ \\
\hline Nilotinib & $\begin{array}{l}\text { Phase II, Delyon, } \\
\text { J., et al. } 2018 \text { [56] }\end{array}$ & $\begin{array}{l}\text { Median age } 70 \text { (range, } \\
62-76) \text { years }\end{array}$ & 25 & $\begin{array}{l}400 \text { mg twice } \\
\text { daily }\end{array}$ & $\begin{array}{l}\text { Median OS and } \\
\text { PFS = } 13.2 \text { and } 6 \\
\text { months, } \\
\text { respectively }\end{array}$ & $1 \mathrm{CR}$ and 4 PRs & $\begin{array}{l}\text { The most common AEs: } \\
\text { fatigue, rash, increased } \\
\text { AST/ALT or cholestasis, and } \\
\text { nausea. Three patients had } \\
\text { drug with drawal because of } \\
\text { grade } 3 \text { AEs }\end{array}$ \\
\hline
\end{tabular}

Abbreviations: AE: adverse event; CR: complete response; OS: overall survival; PD: progressive disease; PFS: progression free survival; PR: partial response; SD: stable disease; TTP: time to progression. 
Table 4. Dasatinib monotherapy or in combination in melanoma clinical trials.

\begin{tabular}{|c|c|c|c|c|c|c|c|}
\hline RTKi & $\begin{array}{c}\text { Phase/ } \\
\text { Year Published or } \\
\text { Presented }\end{array}$ & Population & $N$ & Dose & Survival & Response & Adverse Reactions \\
\hline $\begin{array}{l}\text { Dasatinib } \\
+ \text { Dacar- } \\
\text { bazine }\end{array}$ & $\begin{array}{l}\text { Phase I,Algazi, } \\
\text { A.P., et al. } 2011 \text { [74] }\end{array}$ & $\begin{array}{l}\text { Median age } \\
\quad 62.3\end{array}$ & 50 & $\begin{array}{c}\text { dasatinib } 70 \\
\text { mg } \\
\text { dacarbazine } \\
800 \mathrm{mg} \cdot \mathrm{m}^{-2}\end{array}$ & $\begin{array}{c}\text { Median OS } \\
\text { and PFS = 40.6 } \\
\text { and } 13.4 \text { weeks } \\
\text { respectively }\end{array}$ & $\begin{array}{l}\text { Two patients } \\
\text { showed PRs }\end{array}$ & $\begin{array}{l}\text { The most common } \\
\text { grade } 3 \text { and } 4(\mathrm{AE}) \mathrm{s} \\
\text { were: haematological, } \\
\text { neutropenia, anaemia, } \\
\text { and thrombocytopenia }\end{array}$ \\
\hline Dasatinib & $\begin{array}{l}\text { Phase II, Kluger, } \\
\text { H.M., et al. } 2011 \\
\text { [75] }\end{array}$ & $\begin{array}{l}\text { Median age of } \\
64 \text { (range, } \\
37-84 \text { ) years }\end{array}$ & 39 & $\begin{array}{l}100 \mathrm{mg} \text { PO BID } \\
\text { or } 70 \mathrm{mg} \text { PO } \\
\text { BID }\end{array}$ & $\begin{array}{c}\text { Median OS } \\
\text { and PFS = 55 } \\
\text { and } 8 \text { weeks } \\
\text { respectively }\end{array}$ & $\begin{array}{l}\text { Two patients } \\
\text { showed PRs }\end{array}$ & $\begin{array}{l}\text { The most common } \\
\text { (AE)s were: fatigue, } \\
\text { dyspnea,pleural } \\
\text { effusion, nausea, } \\
\text { anorexia and diarrhea }\end{array}$ \\
\hline Dasatinib & $\begin{array}{l}\text { Phase II,Kalinsky, } \\
\text { K., et al. } 2017 \text { [76] }\end{array}$ & $\begin{array}{l}\text { Median age of } \\
69 \text { (range, } \\
41-87 \text { ) years }\end{array}$ & 30 & $\begin{array}{c}70 \mathrm{mg} \\
\text { orally twice } \\
\text { daily }\end{array}$ & $\begin{array}{c}\text { Median OS } \\
\text { and PFS = 7.5 } \\
\text { and } 2.1 \text { months } \\
\text { respectively }\end{array}$ & $\begin{array}{c}4 \text { of } 22 \\
\text { evaluable } \\
\text { patients had } \\
\text { PRs }\end{array}$ & $\begin{array}{l}\text { The most common } \\
\text { (AE)s: fatigue, dyspnea, } \\
\text { nausea, anemia, pleural } \\
\text { effusion, neutropenia, } \\
\text { vomiting, anorexia, } \\
\text { hypoxia, hypertension } \\
\text { lymphopenia, } \\
\text { myocardial infarction }\end{array}$ \\
\hline
\end{tabular}

Abbreviations: AE: adverse event; OS: overall survival; PFS: progression free survival; PR: partial response.

\subsection{Sunitinib (SUTENT ${ }^{\circledR}$ )}

Sunitinib is an oral multikinase inhibitor that targets the vascular endothelial growth factor receptor (VEGFR) (VEGFR-1, -2, and -3), platelet-derived growth factor receptor (PDGFR) alpha and beta, c-KIT, and FMS-like tyrosine kinase receptor 3 (FLT 3), with potent antiangiogenic and antitumor activity [78]. Sunitinib showed good clinical outcomes in gastrointestinal stromal tumors (GIST) or metastatic renal cell carcinoma (RCC) and received FDA approval for these indications in $2006[79,80]$. First, a preclinical study reported that sunitinib significantly reduces vessel density and induces tumor hypoxia in melanoma xenografts. The latter effect may be beneficial if used as neoadjuvant treatment with radiotherapy or chemotherapy (Table 1) [64]. Another study reported an effect of sunitinib on melanoma tumor microenvironment without affecting tumor size (Table 1) [65]. Indeed, sunitinib inhibited both mutant KIT and VEGF receptors which is advantageous compared to other RTK inhibitors [81]. The first trial aiming at evaluating sunitinib in melanoma patients with mutations, amplifications, or overexpression of KIT showed benefit and proposed further studies (Table 5) [81]. However, a multicenter phase II study did not correlate clinical response to the presence of KIT mutation and attributed it to sunitinib antiangiogenic effect (Table 5) [82]. Another multicenter phase 2 trial in patients with metastatic mucosal or acral melanoma indicates an absence of significant difference between patients with or without KIT mutation (Table 5) [83].

\subsection{Pexidartinib (TURALIOTM)}

Pexidartinib (TURALIO ${ }^{\mathrm{TM}}$ ) is an orally administered small molecule tyrosine kinase inhibitor that targets the colony-stimulating factor 1 (CSF1) receptor, KIT and FMS-like tyrosine kinase 3, showing an internal tandem duplication mutation (FLT3-ITD) [84]. An active phase I/II study to determine pexidartinib safety, pharmacokinetics, and preliminary efficacy in unresectable or metastatic KIT-mutated melanoma was launched in 2015 but is not recruiting anymore. First results posted but not published yet indicate one partial response from the six melanoma patients receiving $1000 \mathrm{mg} /$ day [85]. In addition, a singlearm phase II trial (PIANO; NCT02071940) of pexidartinib in advanced KIT-mutated acral and mucosal melanoma is currently ongoing in the UK [84]. 


\subsection{Ponatinib (Iclusig ${ }^{\circledR}$ )}

Ponatinib was initially designed to inhibit BCR-ABL; other studies show its ability to target other kinases such as FLT3, c-KIT, FGFR, VEGFR, PDGFR, and c-SRC; consequently, it was classified as a multi-TKI [86]. It is an FDA-approved drug for chronic myeloid leukemia (CML) that showed promising outcomes in KIT-mutant PDX melanomas by comparing ponatinib to other RTK inhibitors [66]. Ponatinib downregulates phosphorylation of key signaling pathway mediators, particularly KIT, AKT, and ERK in a dose-dependent manner in all KIT-mutated PDX models (Table 1). In addition, it showed higher affinity to KIT ${ }^{\mathrm{D} 816 \mathrm{~V}}$, a mutation located in the activating loop domain not recognized by most of the other RTK inhibitors including imatinib [66].

Table 5. Sunitinib in melanoma clinical trials.

\begin{tabular}{|c|c|c|c|c|c|c|c|}
\hline RTKi & $\begin{array}{c}\text { Phase/ } \\
\text { Year Published or } \\
\text { Presented }\end{array}$ & Population & $N$ & Dose & Survival & Response & Adverse Reactions \\
\hline Sunitinib & $\begin{array}{c}\text { Phase 2, Minor, } \\
\text { D.R., et al. } 2012 \\
\text { [81] }\end{array}$ & $\begin{array}{l}\text { Median age } 75 \\
\text { (range, 39-92) } \\
\text { years }\end{array}$ & 12 & $\begin{array}{l}50 \mathrm{mg} / \mathrm{d} \text {, dose } \\
\text { modifications } \\
\text { sequentially to } \\
37.5 \text { and } 25 \\
\mathrm{mg} / \mathrm{d} \text { for } \\
\text { grade III or IV } \\
\text { toxicities. }\end{array}$ & $\begin{array}{c}\text { Median } \\
\text { survival = } 6 \\
\text { months } \\
\text { (patients with } \\
\text { KIT } \\
\text { mutations); } \\
\text { PFS = 15 } \\
\text { months }\end{array}$ & $\begin{array}{l}1 \mathrm{CR}, 2 \text { PRs } \\
\text { in the } 4 \text { KIT } \\
\text { patients and } \\
1 \mathrm{PR} \text { in } 6 \\
\text { patients with } \\
\text { KIT } \\
\text { amplification }\end{array}$ & $\begin{array}{c}\text { The frequently } \\
\text { observed toxicities: } \\
\text { nausea or vomiting, } \\
\text { skin and subcutaneous } \\
\text { disorders, hematologic } \\
\text { toxicity, fatigue, and } \\
\text { hypertension }\end{array}$ \\
\hline Sunitinib & $\begin{array}{l}\text { Phase II study, } \\
\text { Decoster, L., et al. } \\
2015 \text { [82] }\end{array}$ & $\begin{array}{c}\text { Median age of } \\
55 \text { years }\end{array}$ & 39 & $\begin{array}{c}50 \mathrm{mg} / \mathrm{d} \text { for } 4 \\
\text { weeks, } \\
\text { followed by } 2 \\
\text { weeks off, }\end{array}$ & $\begin{array}{c}\text { The median OS } \\
\text { and PFS }=4.3 \\
\text { and } 1.3 \\
\text { months, } \\
\text { respectively }\end{array}$ & $\begin{array}{c}\text { PRs were } \\
\text { observed in } 4 \\
\text { patients }\end{array}$ & $\begin{array}{l}\text { The most grade } 3 \text { or } 4 \\
\text { (AE)s were asthenia, } \\
\text { thrombocytopenia, } \\
\text { neutropenia, and } \\
\text { anorexia }\end{array}$ \\
\hline Sunitinib & $\begin{array}{l}\text { Phase } 2 \text { trial, } \\
\text { Bucbinder, E.I., } \\
\text { et al. } 2015 \text { [83] }\end{array}$ & $\begin{array}{l}\text { Median age of } \\
63 \\
\text { (range } 38-86 \text { ) } \\
\text { years }\end{array}$ & 52 & $\begin{array}{l}50 \mathrm{mg} \text { daily or } \\
37.5 \mathrm{mg} \text { daily } \\
\text { for } 4 \text { weeks of } \\
\text { a } 6 \text {-week cycle }\end{array}$ & $\begin{array}{c}\text { The median OS } \\
\text { and PFS = } 7.7 \\
\text { and } 3.1 \\
\text { months, } \\
\text { respectively }\end{array}$ & $\begin{array}{c}4 \text { patients } \\
\text { showed PRs }\end{array}$ & $\begin{array}{l}\text { The most common } \\
\text { (AE)s were fatigue, } \\
\text { leukopenia, } \\
\text { thrombocytopenia, } \\
\text { nausea, neutropenia, } \\
\text { and diarrhea }\end{array}$ \\
\hline
\end{tabular}

Abbreviations: AE: adverse event; OS: overall survival; PFS: progression free survival; CR: Complete Response; PR: partial response; SD: stable disease.

\subsection{Sorafenib-Nexavar ${ }^{\circledR}$}

Sorafenib is an oral drug originally designed to inhibit RAF serine/threonine kinases (RAF-1, wild-type BRAF, ${ }^{V 600 E}$ BRAF), but later in vitro studies indicated its efficacy against several receptor tyrosine kinases associated with tumor angiogenesis, such as VEGFR-2, VEGFR-3, PDGFR- $\beta$, and progression such as c-KIT and FLT-3 [87]. A clinical trial aimed to investigate efficacy and safety of sorafenib monotherapy in patients with progressive advanced melanoma showed its safety but indicated its modest clinical effect [87].

\subsection{1. c-KIT Inhibitors and Future Perspectives}

X-ray crystallography of c-KIT has revealed various active and inactive conformational states that affect interaction with RTK inhibitors [88]. The active conformations are characterized by certain states of the activation loop, phosphate-binding loop (P-loop), and helix $C$, which direct the catalytic machinery to phosphorylate substrates. In the inactive conformation, one or more of these elements are in others states, which does not allow substrate binding and/or catalysis [89]. Crystallographic studies have shown that imatinib binds the inactive conformation and KIT-imatinib interaction deviates from the auto inhibited inactive KIT kinase; this prevents inhibition of A-loop mutations, as it confers an active state of the kinase and confers decreased sensitivity to imatinib (Figure 1C). Despite that, a second generation of KIT inhibitors were developed and expected to be more efficient; as they bind to both active and inactive conformations of c-KIT, imatinib remains the c-KIT inhibitor of choice in comparison to other c-KIT inhibitors in melanoma. This is due to 
other constraints associated with other kit inhibitors such high clinical toxicity (sunitinib) or activation of other mechanisms that counteract drug clinical activity (dasatinib, nilotinib). The limited efficiency of imatinib and its derivatives indicates the importance of the development of new c-KIT inhibitors with specific consideration of the binding potential to both active and inactive conformations of the receptor.

\subsection{EGFR}

The epidermal growth factor receptor (EGFR) was the first receptor tyrosine kinase (RTK) discovered and is a type I glycoprotein located on chromosome 7p11-13 that includes ErbB2, ErbB3, and ErbB4 [90]. In humans, several ligands have been identified to bind to the EGFR family: EGF, TGF $\alpha$, AREG, HB (heparin binding)-EGF and a number of virallyencoded factors [91]. Importantly, these ligands may activate different biological processes within the same cell [92]. For example, TGF $\alpha$ and AREG stimulate higher proliferation than do EGF and heparin [93].

EGFR comprises an extracellular domain (ECD) composed of 620 residues, a kinase domain (residues 685-957) connected by a transmembrane helix (residues 621-642), and a short juxtamembrane segment [94]. This family is characterized by ligand binding to the glycosylated external domain composed of four subdomains designated domain I, II, III, and IV or L1, S1, L2, and S2, respectively (Figure 2A). The domains I and III form the ligand binding domain of EGFR, while other parts mediate receptor dimerization and interactions with other membrane proteins (Figure 2B). EGFR monomers predominate before ligand-binding, while after and like other RTKs, they undergo dimerization (homo/heterodimers), in a back-to-back orientation. In this second mode of dimerization, ligand mediates dimerization through physical interaction between receptors. In its inactive state (absence of ligand), the extracellular region adopts a "tethered" configuration consisting in a dimerization by a $\beta$-hairpin within subdomain II of the ECD, and interaction with domain IV to consequently form an intramolecular autoinhibitory conformation [4]. Ligands bind simultaneously to the two sites in ECD subdomains I and III, rather than binding two separate receptors as is the case with SCF (see above). This induces a dramatic conformational change, particularly an extension in the ECD to expose the buried dimerization arm (subdomain II and IV) in an active state [4] that consequently favors intracellular conformational changes and allows kinase activation (Figure 2B) [94]. The latter contributes to stabilizing extracellular contacts, allowing the movement of the transmembrane helices and a destabilization of the intracellular contacts between the C-terminal and the kinase domains. The active kinase form is mediated by allosteric mechanism rather than phosphorylation, by which the c-terminal lobe of one kinase forms an asymmetric dimer with the $\mathrm{N}$-terminal lobe of the second kinase following dimerization and constitutes a complex known as CDK/cyclin-like complex $[95,96]$. Like other kinases, receptor dimerization results in a transphosphorylation of tyrosine residues in the C-terminal domain, which serve as docking sites for signaling molecules that contain SH2 or PTB domains to consequently activate signaling pathways [97]. Unlike most kinases, phosphorylation of the EGFR activation loop is not mandatory for its activation. Ligand binding favors a contact between the extracellular domains, causing a destabilization of the intermonomer contacts within the intracellular domain, causing its complete activation $[98,99]$. Thus, interaction between the intracellular domains regulates receptor activity [100]; particularly, the C-terminal domain acts as an inherent negative regulator [94]. Ligand-induced receptor internalization and degradation results in signal attenuation with net removal of either the receptor itself in the case of non-dissociative ligands like EGF, or the ligand for dissociative ligands such as TGF $\alpha$ [91]. Receptor endocytosis relies on specific adaptins and sorting nexins complexing with carboxy-terminal motifs, while the destiny of the receptor depends on its continuous occupancy and kinase activity. 
A

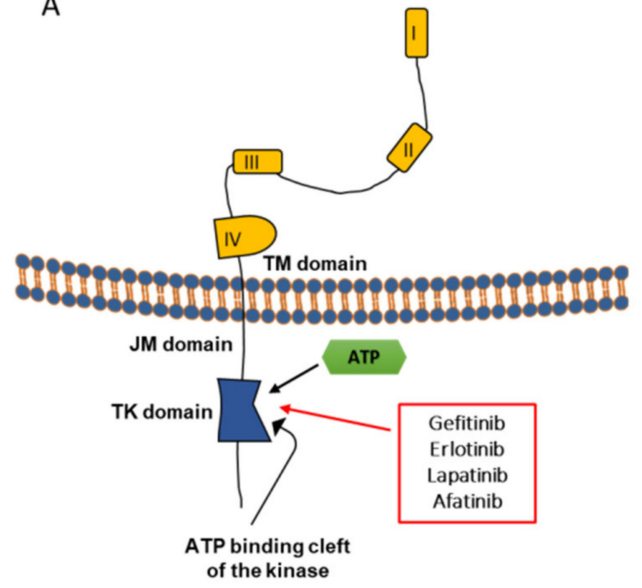

B

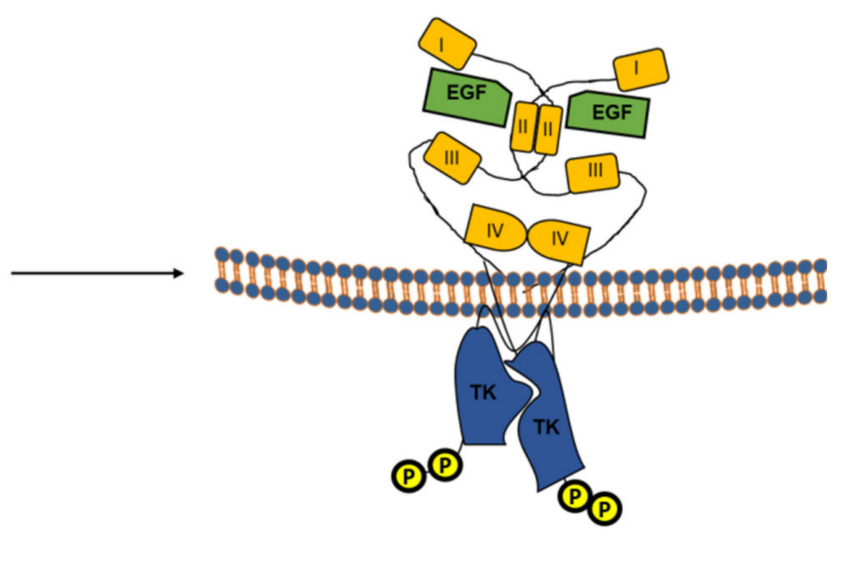

Figure 2. EGFR structure and activation. (A) ECD of EGFR consists of four subdomains noted, respectively, I, II, III, and IV, followed by a transmembrane domain (TM), juxtamembrane domain (JM), and tyrosine kinase domain (TK). (B) Ligand binds to domains I and III simultaneously, and mediates physical interaction between receptors. This favor intracellular conformational changes and kinase activation by allosteric mechanism. EGFR inhibitors are ATP competitor and act by binding the ATP binding cleft.

Gain of function mutations and overexpression of this family of receptors were implicated in a variety of human malignancies, such as mammary carcinomas, squamous cell carcinomas and glioblastomas [2,101]. Due to the functional involvement of EGFR in diverse cellular mechanisms, several therapeutical strategies have been developed in various human malignancies with either the use of anti-receptor monoclonal antibodies or small molecule tyrosine kinase inhibitors. Each of these approaches has a distinct mechanism of action. While anti-EGFR antibodies bind to extracellular domains, the RTK inhibitors target the intracellular TK domain [102].

In melanoma, EGFR, HER3 and HER4 high expression was correlated with poor prognosis [103]. In 1985, Koprowski H. et al. reported for the first time an association between increased dosage of chromosome 7 and EGF receptor expression with melanoma progression [104] an observation confirmed in vivo [105] and in preclinical settings [106]. Consequently, studies evidenced that about $89 \%$ of primary cutaneous melanomas and $91 \%$ of melanoma metastases show a high level of either EGF or EGFR expression, suggesting them as targets for therapy $[105,107]$.

EGFR activation during melanoma progression not only leads to the activation of various signaling pathways including PI3K/AKT and MAPK, but also promotes cell switching towards an invasive phenotype associated with loss of E-cadherin that favors release of cadherin-bound $\beta$-catenin; free $\beta$-catenin translocate to the nucleus and activate pro-invasive factors $[108,109]$. In addition, such activation has been also documented to cause secondary drug resistance in BRAF mutated patients under MAPK inhibitors thus opening the way to the use of EGFR inhibitors to overcome such resistance $[20,110,111]$.

EGFR inhibitors are classified into two major groups: the first with monoclonal antibodies, such as cetuximab and panitumumab, and the second with small molecule tyrosine kinase inhibitors [112] that showed different efficacy towards melanoma cells as reported in preclinical and clinical studies. Below, we will discuss the aim and therapeutic effect of each of the tested small molecule EGFR inhibitors in melanoma.

\subsubsection{Gefitinib (Iressa ${ }^{\circledR}$ )}

Gefitinib (IressaTM, ZD1839) is an anilinoquinazoline that was first FDA approved as a monotherapy in 2003 for locally advanced or metastatic NSCLC after failure of platinum based and docetaxel regimens. It is an inhibitor of intracellular tyrosine kinase activity including that of EGFR, by competitively blocking its ATP binding site [113]. A first study, carried out to check the effect of gefitinib on ErbB receptor signaling pathway in 
human melanoma cell lines, showed cell cycle arrest in G0/G1 phase and inhibition of cell growth shuting down PI3K/AKT, Jak/Stat, and MAPK signaling pathways (Table 6) [114]. Accordingly, a phase II study of gefitinib in patients with metastatic melanoma was conducted in 2011 and showed limited benefit, and proposed future combination strategies (Table 7) [115]. Furthermore, it was shown that gefitinib inhibits melanoma cell proliferation and invasion through the VEGF/AKT signaling pathway (Table 6) [116] and a selective inhibition of BRAF could lead to a feedback activation of EGFR that confers adaptive resistance to BRAF inhibitors in both BRAF-mutant colorectal cancer and melanoma. Therefore, simultaneous EGFR and BRAF inhibition was proposed as an effective novel combination strategy. In this context, a preclinical study evidenced that such a combination attenuates cell migration and in vivo colonization of BRAF-mutant melanoma cells (Table 6) [117].

Table 6. EGFR inhibitors in melanoma preclinical studies.

\begin{tabular}{|c|c|c|c|}
\hline RTKi & Cell Lines Used & Results & Literature \\
\hline Gefitinib & $\begin{array}{l}\text { RaH3 } \\
\text { RaH5 (both }{ }^{\text {WT }} \text { BRAF }{ }^{\text {WT }} \text { NRAS) }\end{array}$ & $\begin{array}{l}\text {-Gefitinib exhibits a } \\
\text { dose dependent inhibition of growth, without } \\
\text { effect on apoptosis, favors cell arrest in G1, } \\
\text { increased expression of p27KIP1 and reduces } \\
\text { phosphorylation of ErbB1, ErbB2, ErbB3, } \\
\text { ERK1/2, and AKT. }\end{array}$ & Djerf, E.A., et al. 2011 [114] \\
\hline Gefitinib & $\mathrm{A} 375\left({ }^{\mathrm{V} 600 \mathrm{E}} \mathrm{BRAF}\right)$ & $\begin{array}{l}\text {-Gefitinib suppressed cell proliferation, mRNA, } \\
\text { and protein expression of VEGF and AKT, } \\
\text { invasion and induced apoptosis. }\end{array}$ & Wan, X., et al. 2018 [116] \\
\hline Gefitinib & $\begin{array}{l}\left.\text { A2058 ( }{ }^{\mathrm{V} 600 \mathrm{E}} \mathrm{BRAF}\right), \\
\text { HT168-M1(V600E BRAF), } \\
\text { HT199(V600 BRAF), WM983B } \\
\left.\text { ( }{ }^{\mathrm{V} 600 \mathrm{E}} \text { BRAF), M24met ( }{ }^{61 R} \mathrm{NRAS}\right), \\
\text { MEWO (WT BRAF, WT NRAS) A431 } \\
\text { (squamous carcinoma cells) }\end{array}$ & $\begin{array}{l}\text {-Gefitinib inhibited the activity of EGFR in } \\
\text { HT168-M1 and WM983B. } \\
\text {-Synergistic inhibitory effect of vemurafenib with } \\
\text { gefitinib in BRAF mutant melanoma cells. } \\
\text {-Gefitinib reduced cell migration in just } \\
\text { melanoma cells expressing mutant BRAF, and } \\
\text { inhibited in-vivo liver colonization of WM983B } \\
\text { and HT168-M1 xenografts. }\end{array}$ & Kenessey, I., et al. 2018 [117] \\
\hline $\begin{array}{l}\text { Erlotinib + } \\
\text { Bevacizumab }\end{array}$ & $\begin{array}{l}\left.\text { 518A2 ( }{ }^{\mathrm{V} 600 \mathrm{E}} \mathrm{BRAF}\right), \\
607 \mathrm{~B} \text { (activated Ras), Sk-Mel-28 } \\
\text { ( }{ }^{\mathrm{V} 60 \mathrm{E}} \text { BRAF), } \\
\left.\text { A375 ( }{ }^{\mathrm{V} 600 \mathrm{E}} \mathrm{BRAF}\right) \\
\text { Mel-Juso (Q61L NRAS), } \\
\text { M24met ( }{ }^{61 \mathrm{R}} \text { NRAS), } \\
\text { 6F (isolated from an ovaric } \\
\text { metastasis) }\end{array}$ & $\begin{array}{l}\text {-Erlotinib reduces transmigration in 518A2, } \\
\text { M24met and SK-Mel-28 cells and increase the } \\
\text { antiangiogenic effect of bevacizumab. } \\
\text {-Erlotinib inhibited MEK/AKT pathways. } \\
\text {-Erlotinib in combination with bevacizumab } \\
\text { reduces sprout length in HUVECs conditioned } \\
\text { with 518A2 and in cells conditioned with } \\
\text { M24met medium. } \\
\text {-Erlotinib and bevacizumab reduce tumor } \\
\text { volume and proliferation, enhance apoptosis, } \\
\text { and reduce lymph node diameter and lung } \\
\text { metastasis in mice injected with 518A2. }\end{array}$ & Schicher, N., et al. 2009 [118] \\
\hline Erlotinib + Ad-IL-24 & $\begin{array}{l}\text { WM35(V600E BRAF), } \\
\left.\text { WM793 ( }{ }^{\mathrm{V} 600 \mathrm{E}} \mathrm{BRAF}\right), \\
\left.\text { A375( }{ }^{\mathrm{V} 600 \mathrm{E}} \mathrm{BRAF}\right), \\
\left.\text { MeWo ( }{ }^{\mathrm{WT}} \mathrm{BRAF},{ }^{\mathrm{WT}} \mathrm{NRAS}\right) \\
\text { (metastatic), } \\
\left.\text { Skmel-2 ( }{ }^{\mathrm{Q} 61 \mathrm{R}} \mathrm{NRAS}\right), \\
\text { SB2 (advanced-stage), } \\
\text { Mel-2 (metastatic, passage 6) } \\
\text { Mel-3(metastatic, passage3), A431 } \\
\text { (squamous carcinoma) }\end{array}$ & $\begin{array}{l}\text {-Erlotinib decreased the cell viability } \\
\text { of WM35, WM793, A375, and MeWo cells. } \\
\text {-Co-treatment of melanoma } \\
\text { cells with Ad-IL-24 and erlotinib decreases cell } \\
\text { growth and enhanced apoptosis through Apaf-1 } \\
\text { and AKT signaling pathways. }\end{array}$ & Deng, W.G., et al. 2011 [119] \\
\hline
\end{tabular}


Table 6. Cont.

\begin{tabular}{|c|c|c|c|}
\hline RTKi & Cell Lines Used & Results & Literature \\
\hline $\begin{array}{l}\text { Lapatinib or Gefitinib + } \\
\text { Foretinib }\end{array}$ & $\begin{array}{l}\text { A375( }\left({ }^{\mathrm{V} 600 \mathrm{E}} \mathrm{BRAF}\right) \\
\mathrm{Hs} 294 \mathrm{~T}\left({ }^{\mathrm{WT}} \mathrm{BRAF}\right) \\
\text { WM9(V60E } \mathrm{BRAF})\end{array}$ & $\begin{array}{l}\text {-Lapatinib/gefitinib shows slight effect alone but } \\
\text { in combination with foretinib decreased } \\
\text { melanoma cell viability in A375 and Hs294T } \\
\text { cells. The WM9 cell was the most resistant to } \\
\text { treatment. } \\
\text {-Foretinib alone/with EGFR inhibitors reduced } \\
\text { proliferation of A375, induced higher apoptosis } \\
\text { in Hs294T than A375, and reduced pAkt and } \\
\text { pErk levels. } \\
\text {-Lapatinib/gefitinib does not affect cell } \\
\text { morphology or actin cytoskeleton organization, } \\
\text { but foretinib alone or in combination changed } \\
\text { nuclei morphology } \\
\text {-Foretinib alone or its combination with } \\
\text { lapatinib/gefitinib induced G2/M cycle arrest in } \\
\text { A375, Hs294T and WW9 cells. }\end{array}$ & $\begin{array}{l}\text { Dratkiewicz, E., et al. } 2018 \\
\text { [120] }\end{array}$ \\
\hline $\begin{array}{l}\text { Lapatinib or Gefitinib + } \\
\text { Foretinib }\end{array}$ & $\begin{array}{l}\text { A375( }\left({ }^{\mathrm{V} 600 \mathrm{E}} \mathrm{BRAF}\right) \\
\text { Hs294T }\left({ }^{\mathrm{WT}} \mathrm{BRAF}\right) \\
\text { WM9 }\left({ }^{\mathrm{V} 600 \mathrm{E}} \mathrm{BRAF}\right)\end{array}$ & $\begin{array}{l}\text {-This combination is effective in WM9 and } \\
\text { Hs294T, while in A375 cells, the effect was } \\
\text { similar to foretinib alone in terms of reduction of } \\
\text { cell migration. } \\
\text {-This combination reduces invasion in A375 and } \\
\text { WM9 cells but is less evident in Hs } 294 \mathrm{~T} \text { cells. } \\
\text {-Foretinib alone or in combination decreases } \\
\text { proteolytic activity. }\end{array}$ & $\begin{array}{l}\text { Simiczyjew, A., et al. } 2019 \\
\text { [108] }\end{array}$ \\
\hline Lapatinib + Foretinib & $\begin{array}{l}\text { A375 }\left({ }^{\mathrm{V} 600 \mathrm{E}} \mathrm{BRAF}\right) / \mathrm{A} 375 \mathrm{RL} \text { and } \\
\left.\text { WM9 ( }{ }^{\mathrm{V} 600 \mathrm{E}} \mathrm{BRAF}\right) / \mathrm{WM} 9 \mathrm{RL}\end{array}$ & $\begin{array}{l}\text {-This combination or foretinib alone inhibit } \\
\text { viability and migration in both resistant cells, } \\
\text { especially in WM9 RL. }\end{array}$ & $\begin{array}{l}\text { Dratkiewicz, E., et al. } 2020 \\
\text { [121] }\end{array}$ \\
\hline $\begin{array}{l}\text { Gefitinib or } \\
\text { Afatinib/BIBW2992+ } \\
\text { MK-2206/GSK692094 }\end{array}$ & vemurafenib-resistant YUKSI cells & $\begin{array}{l}\text {-Afatinib/BIBW2992 paired with } \\
\text { MK-2206/GSK692094 and reduced growth. }\end{array}$ & Held, M.A., et al. 2013 [122] \\
\hline Afatinib + crizotinib & $\begin{array}{l}\left.\text { A375 ( }{ }^{\mathrm{V} 600 \mathrm{E}} \mathrm{BRAF}\right), \\
\left.\text { SkMel24( }{ }^{\mathrm{V} 600 \mathrm{E}} \mathrm{BRAF}\right), \\
\text { SkMel28 (V600E BRAF), A375PR1\& } \\
\text { A375VR4 were PLX4720 or } \\
\text { vemurafenib-resistant sublines } \\
\text { derived from A375, } \\
\text { SkMel2 (Q61R NRAS), ESTDAB102 } \\
\text { (Q61R NRAS), ESTDAB105 } \\
\text { ('WTBRAF/NRAS), ESTDAB138 } \\
\text { (WT BRAF/NRAS), ESTDAB140 } \\
\text { (WTBRAF/NRAS) ESTDAB149 } \\
\text { ('Q61R NRAS) }\end{array}$ & $\begin{array}{l}\text {-This combination decreased cell proliferation, } \\
\text { colony formation, invasion, promoted cell death } \\
\text { in distinct melanoma cells, and decreased tumor } \\
\text { growth rate. }\end{array}$ & Das, I., et al. 2019 [123] \\
\hline
\end{tabular}

Table 7. EGFR inhibitors evaluated in different melanoma clinical trials.

\begin{tabular}{|c|c|c|c|c|c|c|c|}
\hline RTKi & $\begin{array}{l}\text { Phase/Year } \\
\text { Published or } \\
\text { Presented }\end{array}$ & Population & $\mathbf{N}$ & Dose & Survival & Response & Adverse Reactions \\
\hline Gefitinib & $\begin{array}{l}\text { Phase II, Patel, } \\
\text { S.P., et al. } 2011 \\
\text { [115] }\end{array}$ & $\begin{array}{l}\text { Median age of } \\
62.5 \text { years, } \\
\text { (range, 19-90) } \\
\text { years }\end{array}$ & 52 & $250 \mathrm{mg} /$ day & $\begin{array}{c}\text { Median OS and } \\
\text { PFS = 9.7 and } 1.4 \\
\text { months, } \\
\text { respectively }\end{array}$ & $\begin{array}{l}\text { Two PRs and } \\
13 \text { showed SD }\end{array}$ & $\begin{array}{c}\text { Well tolerated } \\
\text { drug, and fatigue } \\
\text { was the only grade } \\
3 \text { adverse event. }\end{array}$ \\
\hline $\begin{array}{c}\text { Erlotinib+ } \\
\text { Bevacizumab }\end{array}$ & $\begin{array}{c}\text { Phase II } \\
\text { trial,Mudigonda, } \\
\text { T.V., et al. } 2016 \\
\text { [124] }\end{array}$ & $\begin{array}{c}\text { Median age of } \\
60 \text { years, } \\
\text { (range, 18-65) } \\
\text { years }\end{array}$ & 28 & $\begin{array}{l}150 \mathrm{mg} / \text { day of } \\
\text { erlotinib and } \\
10 \mathrm{mg} / \mathrm{kg} \text { of } \\
\text { bevacizumab }\end{array}$ & $\begin{array}{l}\text { Median OS and } \\
\text { PFS = } 6.7 \text { and } 2 \\
\text { months, } \\
\text { respectively }\end{array}$ & $\begin{array}{l}\text { Two PRs and } \\
11 \text { showed SD }\end{array}$ & $\begin{array}{c}\text { Rare grade } 3-4 \\
\text { events: fatigue and } \\
\text { dysarthria. }\end{array}$ \\
\hline
\end{tabular}

Abbreviations: AE: adverse event; OS: overall survival; PFS: progression free survival; PR: partial response; SD: stable disease.

\subsubsection{Erlotinib (TARCEVA ${ }^{\circledR}$ )}

Erlotinib is a reversible, ATP-competitive inhibitor of EGFR dimerization and autophosphorylation with higher binding affinity for exon 19 deletions and exon 21 receptor 
mutations [125]. It showed efficacy in the treatment of non-small cell lung, colon, and pancreatic cancer and glioblastoma and was approved for the treatment of locally advanced or metastatic non-small cell lung cancer and pancreatic cancer [126].

In melanoma, as EGFR was shown to affect tumor cell functions from proliferation to differentiation as well as cell death, and as VEGF has been identified as a potent contributor to angiogenesis, tumor proliferation, and lymphangiogenesis, a first preclinical study was launched to evaluate the effect of erlotinib and bevacizumab in a human melanoma xenograft model. No effect was observed with erlotinib or bevacizumab on tumor cell proliferation, but a decreased invasive potential with erlotinib treatment in a 3D matrigel assay was shown. The combination significantly reduced angiogenesis, tumor volume and increased apoptosis (Table 6) [118]. However, a phase II trial found the combination largely ineffective in melanoma and does not merit further exploration (Table 7) [124]. Erlotinib was also combined to interleukin 24 (IL-24) based on the later expression in normal melanocytes, monocytes, and in early stages of melanoma, but was lost during progression [127,128]. IL-24 exhibits its anti-tumor activity in a broad spectrum of cancers including melanoma [129-131] through inhibition of PI3K, EGFR, and PKR induction in breast and NSCLC [132,133]. However, IL-24 molecular mechanisms and signaling pathways underlying melanoma suppression were not described and even less in combination with EGFR targeted therapy. Nevertheless, a preclinical study indicated a benefit from Ad-IL-24 and erlotinib in terms of tumor growth inhibition and induction of apoptosis through Apaf-1 and AKT signaling pathway inhibition (Table 6) [119].

\subsubsection{Lapatinib (Tyverb ${ }^{\circledR}$ )}

Lapatinib is an oral reversible dual tyrosine kinase inhibitor that blocks EGFR and HER2, both frequently overexpressed in human cancer. Lapatinib selectively targets both EGFR and HER2 and acts in a similar way to gefitinib but in contrast to other EGFR inhibitors, can bind to an inactive form of its target [134]. Several reports indicates that ErbB and MET were found highly deregulated in melanoma patients, which made these receptors promising therapeutic targets to evaluate. Targeting each receptor alone requires administration of higher doses of the drug which often leads to acquired resistance to monotherapy along with several works indicating a crosstalk between MET and EGFR [108]. This interaction could be responsible for amplification of tumor signal transduction and receptor function compensation when only one of these receptors is inhibited. Consequently, combined therapy targeting both receptors was predicted to be effective to suppress activation of shared signal transducing pathways and crosstalk-induced positive feedback loops [120]. This combination (foretinib "MET inhibitor" and lapatinib or gefitinib) showed synergistic effect in different melanoma cells with different levels of RTK (cells express EGFR and MET) (Table 6) [120]. In continuity, and following the preclinical success of this combination in melanoma, it was tested for its efficiency on cell invasion ability and metastasis. Lapatinib alone inhibits invadopodia formation. Combining lapatinib or gefitinib with foretinib influences migration, invasion, invadopodia formation, actin cytoskeleton organization and proteolytic activity that consequently predict important combination therapeutic strategy to prevent melanoma growth and metastasize (Table 6) [108]. Moreover, hyperactivation and overexpression of RTKs were described as one of the mechanisms of acquired resistance to BRAF inhibitors through reactivation of key signaling pathways (MAPK, PI3K/AKT) and changes in the cells' interactions with the tumor microenvironment [135]. Particularly, a hyperactivation in EGFR and MET in cells with acquired resistance to BRAF inhibitors was shown; consequently, this combination (lapatinib+foretinib) was tested for its efficiency in BRAF resistant melanoma cells. It was reported that this combination reduces cell viability and invasiveness of drug-resistant cells (Table 6) [121]. However, more benefits could be expected from irreversible EGFR-TKIs and combined treatment settings. 


\section{Second Generation of EGFR TK Inhibitors}

Acquired resistance to the first generation of EGFR TKIs has prompted the clinical development of more potent and effective compounds with irreversible and covalent binding to the EGFR kinase domain with a broader spectrum of mutations including T790M [136]. Unlike reversible EGFR inhibitors, this generation contains an acceptor-group that binds covalently with the Cys797 at the ATP-binding site of mutant EGFR. Due to their characteristics, irreversible EGFR inhibitors seemed to be ideal to overcome T790M acquired resistance [137].

\subsubsection{Afatinib (Giotrif $\left.{ }^{\circledR}\right)$}

Afatinib is an irreversible autophosphorylation inhibitor of the ErbB family of tyrosine kinases (EGFR, HER2 and HER4) [138]. It can overcome a specific resistance to EGFR inhibitors conferred by EGFR-T790M mutation in lung cancer [123]. In melanoma, afatinib was tested and, as gefitinib and lapatinib, it showed minimal cytotoxic activity alone but was more effective when combined with AKT inhibitors in vemurafenib resistant BRAF mutated melanoma (Table 6) [122]. Another combination of afatinib with crizotinib (a MET inhibitor) showed efficacy, was proposed as a promising alternative targeted therapy option for melanoma irrespective of BRAF/NRAS mutational status, and may overcome resistance to BRAF inhibitors (Table 6) [123].

\subsection{HGFR (MET Receptor)}

The hepatocyte growth factor receptor is a proto-oncogene that encodes a tyrosine kinase receptor located on chromosome 7 band 7q21-q31 and covers more than $120 \mathrm{~kb}$ in length, consisting of 21 exons separated by 20 introns [139]. Hepatocyte growth factor (HGF) was identified as a natural ligand for Met receptor protein [140] along with scatter factor (SF), indicating that, alone, it can transduce multiple biological processes such as motility, proliferation, survival, and morphogenesis [139]. The Met receptor is a member of a larger family of growth factor receptors sharing a similar domain architecture that includes the Ron (macrophage stimulating 1-receptor [141]) and Sea (receptors of poorly characterized biological functions [142]) receptors. HGF and HGFR are essential for normal development. In adults, both are widely expressed in several tissues, but their expression is normally very low and particularly involved mainly in tissue damage, repair, and regeneration [143]. HGFR consists of $\alpha$ and $\beta$ chain subunits linked by a disulfide bond. The $\beta$ chain consists of an extracellular domain, a transmembrane domain, and an intracellular portion. The extracellular portion of Met family members is composed of three domain types (sema, PSI, and IPT). The N-terminal (500 residues) fold into a sema domain, which form a seven-bladed $\beta$-propeller structure. The second, the PSI domain (50 residues) containing four disulfide bonds, follows the sema domain and is connected via the third segment IPT domain to the transmembrane helix and the kinase domain in the intracellular portion of the receptor. IPT domains are related to immunoglobulin-like domains (Figure 3A). The PSI domain is thought to function as a linking module to orient the extracellular fragment of Met for proper ligand binding [144]. Other reports claimed that the sema domain is the ligand binding domain of HGF [145]. Furthermore, others indicate that IPT repeats 3 and 4, found near the transmembrane domain, also serve as HGF binding [146]. Crystallographic analysis indicated that residues Thr124-Asp128 and Asp190-Phe192 in the Sema domain serve as binding interface to HGF $[147,148]$. The extracellular domain, shown as a rod-shaped monomer, binds HGF/SF in the absence or presence of accessory molecule heparin, and could form a complex HGF/SF-heparin-MET with a 1:1:1 stochiometry [145]. The intracellular domain of MET receptor comprises a tyrosine kinase catalytic domain delimited by juxtamembrane and carboxy-terminal sequences. Phosphorylation of tyrosine 1003 in the juxtamembrane region negatively regulates this receptor through activation of the ubiquitin ligase casitas B-lineage lymphoma (c-CBL). Following HGF binding, receptor autophosphorylation occurs on tyrosine residues Y1234 and Y1235 within the activation loop of the TK domain, inducing kinase activity, while 
phosphorylation on Y1349 and Y1356 in the carboxyl terminal region serves as docking site for adapters protein that transmit signals downstream (Figure 3B) $[149,150]$. Signaling mediators involved in this pathway include Grb2, Gab1, PI3K, phospholipase C-gamma (PLC $\gamma)$, Shc, Src, Shp2, Ship1 and STAT3. Of interest, Grb2 binding to docking site through Y1356 links c-Met to the MAPK pathway that regulates the cell cycle. Met signaling crosstalked/cross-linked with other signaling downstream from several membrane receptors such as RON, EGFR and ErbB2 and could assume a mechanism of resistance for cancer progression [143]. Furthermore, it was indicated that MET major signaling is the PI3K/Akt signaling axis. The p85 subunit of PI3K can bind either directly to c-MET or indirectly through adaptor GAB1, and favor signals through AKT/protein kinase B [151]. In human malignancies, the HGF-MET pathway was found altered by several mechanisms, providing tumor cells the capacity to proliferate and disseminate. The MET gene is activated by point activating mutations in small-cell lung cancer (SCLC) [152] and renal papillary carcinomas [153]. MET protein was found overexpressed in melanoma and musculoskeletal tumors [154]. Additionally, activation of the HGF-MET pathway by overexpression and up regulation has been described as the escape resistance mechanism of tumor cells against inhibition of the EGFR, RAS-RAF-MEK, and Akt-mTOR (mammalian target of rapamycin) pathways $[155,156]$.
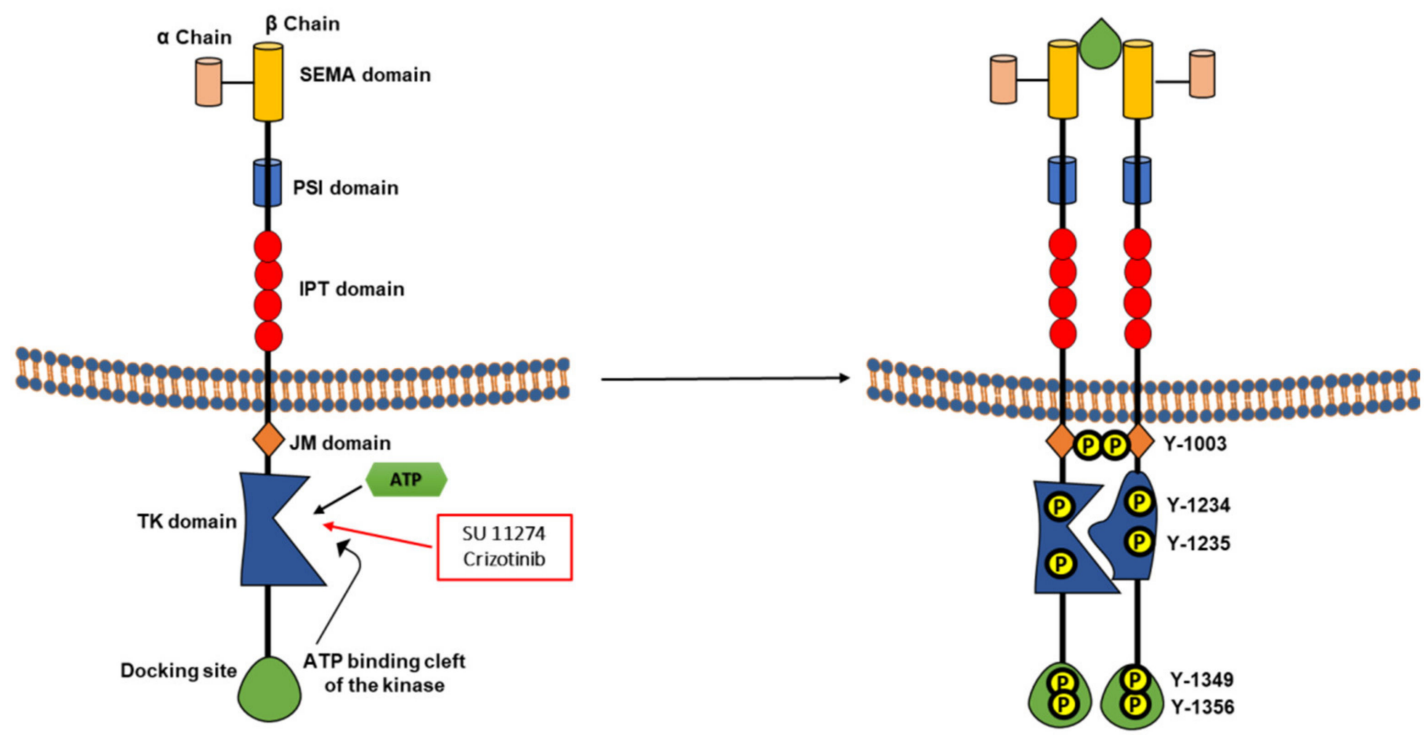

Figure 3. HGFR structure and activation. (A) ECD domain of HGFR consists of disulfide bond-linked $\alpha$ and $\beta$ subunits, which consist of Sema, PSI, and IPT domains, followed by a transmembrane domain (TM), juxtamembrane domain (JM), tyrosine Kinase domain (TK), and docking sites for adaptor proteins. (B) HGF/SF in absence or presence of accessory molecule such heparin bind ECD (dimerization) that mediates autophosphorylation of specific tyrosine residues (Y1003, Y-1234, Y1235, Y1349, Y1356). HGFR-tyrosine kinase inhibitors bind the ATP-binding pocket of the kinase domain.

In melanoma, MET is involved in melanomagenesis (melanoma initiation [157], malignant transformation of melancoyte) and progression. Its overexpression in primary lesions, indicates that it could be an important factor of aggressiveness [158]. In addition, MET gene amplification [159] and an autocrine HGF/c-Met signaling loop may be involved in melanomagenesis, but the mechanism remains unclear [160]. Furthermore, prolonged HGF stimulation favors a decrease in the intercellular adhesive molecule E-cadherin involved in the regulation of melanocyte proliferation [160]. Importantly, Met is regulated by MITF, the master transcription factor within melanocyte, and driven expression of MITF is sufficient to increase MET expression [161]. In some cases, Met activation could be associated with NRAS mutation in melanoma [162]. The release of HGF leading to HGFR activation was associated with resistance to BRAF inhibition in melanoma [163,164]. Thus, MET receptor 
appeared as a potential therapeutic target in melanoma [165]. Below, we will discuss different strategies tested in preclinical and clinical studies of MET inhibition alone or in combination in melanoma.

\subsubsection{SU 11274}

SU 11274 is a pyrrole indolinone class I c-Met inhibitor selective for Y1234 and Y1235 residues that competes for the Mg-ATP complex binding pocket and is the first small compound developed to specifically inactivate Met kinase function [166]. Due to several reports indicating that MET overexpression correlates with melanoma development and invasiveness, SU11274 was tested and showed efficiency inhibiting growth, enhancing apoptosis and differentiation (Table 8) [167]. In human melanoma xenografts, it reduces tumor growth and liver colonization (Table 8) [168]. Specifically, SU11274 inhibited melanoma cell proliferation, affected cell morphology, increased tumorogenecity in vivo, and altered energetic metabolism and provided evidence for a critical glycolysis regulation in melanoma initiating cells (Table 8) [169]. Moreover, resistance to SU11274 in melanoma was accompanied with an up-regulation of WNT and mTOR signaling pathways. Accordingly, targeting mTOR and WNT pathways by everolimus and XAV939, respectively, enhanced the SU11274 effect (Table 8) [170]. However, despite promising preclinical results, this compound was not a viable clinical agent.

Table 8. Met inhibitors in melanoma preclinical studies.

\begin{tabular}{|c|c|c|c|}
\hline RTKi & Cell Lines Used & Results & Literature \\
\hline SU11274 & $\begin{array}{l}\text { MM-AN, MU, PM-WK, MM-RU, } \\
\text { MM-MC, MM-LH, and RPM-EP }\end{array}$ & $\begin{array}{l}\text {-SU11274 inhibits proliferation and induces cell death } \\
\text { in all melanoma cells expressing MET. } \\
\text {-SU11274 induces a differentiated phenotype in } \\
\text { MM-RU, MU, and MM-MC. } \\
\text {-SU11274 decreases ROS and inhibits tyrosine } \\
\text { phosphorylation of c-Met in MU melanoma cells. }\end{array}$ & Puri, N., et al. 2007 [167] \\
\hline SU11274 & $\begin{array}{l}\text { HT168 }\left({ }^{\mathrm{V} 600 \mathrm{E}} \mathrm{BRAF}\right), \\
\left.\text { HT168-M1( }{ }^{\mathrm{V} 600 \mathrm{E}} \mathrm{BRAF}\right), \\
\text { HT199 }\left({ }^{\mathrm{V} 600 \mathrm{E}} \mathrm{BRAF}\right), \\
\left.\text { WM35 ( }{ }^{\mathrm{V} 600 \mathrm{E}} \mathrm{BRAF}\right), \\
\left.\text { WM983A ( }{ }^{\mathrm{V} 60 \mathrm{E}} \mathrm{BRAF}\right), \\
\left.\text { WM983B ( }{ }^{\mathrm{V} 600 \mathrm{E}} \mathrm{BRAF}\right), \\
\left.\text { M24met ( }{ }^{61} \mathrm{NRAS}\right), \\
\text { HT168-M1 human melanoma cells } \\
\text { in SCID-mice }\end{array}$ & $\begin{array}{l}\text {-SU11274 inhibited Met phosphorylation in HT168-M1 } \\
\text { cells. } \\
\text {-SU11274 inhibited cells proliferation in HT168-M1, } \\
\text { HT199, WM983B, and M24met. } \\
\text {-SU11274 favor apoptosis and inhibit migration of } \\
\text { HT168- } \\
\text { M1 cells. } \\
\text {-SU11274 inhibited intrasplenic growth and liver } \\
\text { colonization of HT168-M1 xenograft. }\end{array}$ & Kenessey, I., et al. 2010 [168] \\
\hline SU11274 & $\begin{array}{l}\text { M14 }\left({ }^{\mathrm{V} 600 \mathrm{E}} \mathrm{BRAF}\right), \\
\text { M4Beu, A375 }\left({ }^{\mathrm{V} 600 \mathrm{E}} \mathrm{BRAF}\right), \\
\text { EGFP-A375 and Rel3 (hyper } \\
\text { metastatic variant of A375); } \\
\text { Untreated or SU11274-treated } \\
\text { Rel3 injected into the flank of } \\
\text { immunodeficient mice }\end{array}$ & $\begin{array}{l}\text {-SU11274 increased phosphorylation of c-Met on } \\
\text { Tyr1349 inA375 and Rel3 cells. } \\
\text {-SU11274 inhibits cell proliferation in all melanoma } \\
\text { cells, changes cell morphology, mediates bioenergetic } \\
\text { alterations, increases pluripotent stem cell proteins, } \\
\text { phosphokinase proteome profile, tumor initiation in } \\
\text { Rel3, and mediates in vivo tumorigenicity. }\end{array}$ & $\begin{array}{l}\text { Kucerova, L., et al. } 2016 \\
\text { [169] }\end{array}$ \\
\hline SU11274 & $\begin{array}{l}\left.\text { MU-P ( }{ }^{\mathrm{V} 600 E} \mathrm{BRAF}\right) \\
\text { RU-P, EP-P, WK-P (explant } \\
\text { culture); } \\
\text { MU-R and RU-R (SU11274 } \\
\text { resistant cell lines) }\end{array}$ & $\begin{array}{l}\text {-Treatment with SU11274 favors seven-fold reduction } \\
\text { in tumor size of xenografts from RU-P melanoma cells. } \\
\text {-SU11274 in combination with everolimus and XAV939 } \\
\text { overcome resistance associated to c-Met inhibitor in } \\
\text { MU-R and RU-R cells. }\end{array}$ & Etnyre, D., et al. 2014 [170] \\
\hline Tivatinib & $\begin{array}{l}\left.\text { C8161 ( }{ }^{\mathrm{G} 464 \mathrm{E}} \mathrm{BRAF}\right), \\
\text { WM793 ( }{ }^{\mathrm{V} 600 \mathrm{E}} \text { BRAF), } \\
\text { WM293 ( }{ }^{\mathrm{V} 600 \mathrm{E}} \text { BRAF), } \\
\text { UACC, WM278 ( }{ }^{\mathrm{V} 600 \mathrm{E}} \text { BRAF) }\end{array}$ & $\begin{array}{l}\text {-Tivatinib inhibits cell viability and induces apoptosis } \\
\text { and cytotoxicity in the tested melanoma cells. } \\
\text {-Tivatinib increases vinculin in C } 8161 \text { and UACC cells, } \\
\text { RhoC in C } 8161 \text { cells and reduces zyxin and FN1 } \\
\text { mRNA in C } 8161 \text { and UACC cells. } \\
\text {-Tivatinib decreases VM formation in C8161 and } \\
\text { WM793 cells. }\end{array}$ & $\begin{array}{l}\text { Kumar, S.R., et al. } 2019 \\
\text { [171] }\end{array}$ \\
\hline
\end{tabular}


Table 8. Cont.

\begin{tabular}{|c|c|c|c|}
\hline RTKi & Cell Lines Used & Results & Literature \\
\hline PHA-665752 & $\begin{array}{l}\text { A375 ( }{ }^{\mathrm{V} 600 \mathrm{E}} \text { BRAF), } \\
\text { MeWo } \\
\text { (WT BRAF }{ }^{\mathrm{WT}} \text { NRAS),SK-Mel-2 } \\
\text { (Q61R NRAS), SB2 cells (NRAS } \\
\text { mutants), } \\
\text { WM852 ('61R NRAS), } \\
\text { 451Lu ( }{ }^{\mathrm{V} 600 \mathrm{E}} \text { BRAF), } \\
\text { WM1361A (Q61R NRAS), } \\
\text { WM35 (V600E BRAF) } \\
\text { WM793 ( }{ }^{\mathrm{V} 600 \mathrm{E}} \text { BRAF) }\end{array}$ & $\begin{array}{l}\text {-PHA- } 66752 \text { favors dose dependent inhibition of MET } \\
\text { phosphorylation in all cells and completes Akt } \\
\text { phosphorylation inhibition in NRAS mutant cells. } \\
\text {-IC50 of PHA- } 66752 \text { was lower for NRAS mutant cells. } \\
\text {-PHA-66752 reduces migration and induces G0/G1 cell } \\
\text { cycle arrest and apoptosis more dramatically in NRAS } \\
\text { mutant cells. }\end{array}$ & $\begin{array}{l}\text { Chattopadhyay, C., et al. } \\
2012 \text { [162] }\end{array}$ \\
\hline Quercetin & $\begin{array}{l}\text { A375 ( }{ }^{\mathrm{V} 600 \mathrm{E}} \text { BRAF), } \\
\text { A2058 ( }{ }^{\mathrm{V} 600 \mathrm{E}} \text { BRAF), } \\
\text { SK-Mel-2 (Q61R NRAS) } \\
\text { MeWo ('WT }{ }^{\text {BRAF }}{ }^{\mathrm{WT}} \text { NRAS) }\end{array}$ & $\begin{array}{l}\text {-Quercetin inhibited migration, invasion, MET } \\
\text { activation, and downstream molecules in A375 and } \\
\text { A2058 cells. } \\
\text {-Quercetin reduced c-Met levels through FAS inhibition } \\
\text { in A375, A2058, MeWo, and skmel-2 cells }\end{array}$ & Cao, H., et al. 2015 [172] \\
\hline
\end{tabular}

\subsubsection{Crizotinib (XALKORI $\left.{ }^{\circledR}\right)$}

Crizotinib is a potent, orally bioavailable, ATP competitive small molecule inhibitor of the catalytic activity of c-Met and ALK kinases. It received FDA approval in nonsmall-cell lung cancer, and several studies showed activity in MET-amplified or mutant lung adenocarcinoma, squamous cell carcinoma, and papillary renal cell carcinoma [173]. Crizotinib was not tested for its efficiency in melanoma but was used as an agent to validate the involvement of HGF release in the resistance to mutant-BRAF inhibitors [163]. Nevertheless, preclinical and ongoing clinical studies are evaluating crizotinib in uveal melanoma to prevent metastasis by a defect in ALK gene [174] (NCT02223819).

\subsubsection{Tivantinib}

Tivantinib (ARQ 197) is a non-ATP competitor that selectively inhibits MET. It binds to an inactive, unphosphorylated form of MET and locks it in an inactive state [175]. It showed activity in several tumor cell lines and xenograft models [176]. It is a moderator of tumor invasion and resistance to therapies that target angiogenesis [177]. In patients, tivantinib showed safety profile and anticancer activity in several tumor types [178]. As MET inhibition combined to sorafenib showed additive/synergistic effect in several cancers, a phase I trial was set to evaluate sorafenib and tivatinib combination in solid tumors with high MET activity including melanoma (Table 9) [178]. Although tivatinib was developed to inhibit MET, it recently showed an activity on microtubule polymerization indicating additional targets for this drug. As vasculogenic mimicry was reported for melanoma cells to mediate invasion and metastasis, Tivatinib was tested and found efficient in inhibiting cell viability, inducing apoptosis and reducing vasculogenic mimicry (Table 8) [171].

\subsubsection{PHA-665752}

PHA-665752 is an ATP-competitive of the catalytic activity of the Met receptor. As NRAS mutated melanoma tumors may show aberrant c-Met activation contributing to their aggressive nature, PHA-66752 was tested in this subgroup. PHA-66752 showed a unique sensitivity in NRAS mutant melanoma in terms of cell migration inhibition and apoptosis induction (Table 8) [162].

\subsubsection{Quercetin}

Quercetin, is a bioflavonoid found in a variety of plant-based foods such as onions, apples, tea, broccoli, and red wine. It has been reported as a potent STAT3 inhibitor in glioblastoma and gastric cancer cells [179]. Several studies indicated a significant inhibitory potential of this compound on HGF/Met signaling pathway [180]. In melanoma, Quercetin inhibited cell growth, migration and lung metastases [179]. It inhibits c-Met 
phosphorylation by interfering with c-Met dimerization, and consequently reduces the activities of downstream activated molecules such Gab1, FAK and PAK (Table 8) [172].

Table 9. Clinical trials with MET inhibitor in melanoma.

\begin{tabular}{|c|c|c|c|c|c|c|c|}
\hline RTKi & $\begin{array}{l}\text { Phase/Year } \\
\text { Published or } \\
\text { Presented }\end{array}$ & Population & $\mathbf{N}$ & Dose & Survival & Response & Adverse Reactions \\
\hline $\begin{array}{l}\text { Tivantinib + } \\
\text { Sorafenib }\end{array}$ & $\begin{array}{c}\text { Phase I, } \\
\text { Puzanov, I., } \\
\text { et al. } 2015 \text { [178] }\end{array}$ & $\begin{array}{c}\text { Median age of } \\
65.1 \text { years }\end{array}$ & 19 & $\begin{array}{l}\text { tivantinib } \\
360 \mathrm{mg} \\
\text { BID/sorafenib } \\
200 \text { mg BID) or } \\
\text { tivantinib } \\
360 \mathrm{mg} \\
\text { BID/sorafenib } \\
400 \mathrm{mg} \text { BID }\end{array}$ & $\begin{array}{c}\text { Median PFS = } \\
4.9 \text { months }\end{array}$ & $\begin{array}{c}1 \mathrm{CR}, 4 \\
\text { patients } \\
\text { achieved PRs }\end{array}$ & $\begin{array}{l}\text { The most common AEs } \\
\text { included: rash, } \\
\text { diarrhea, anorexia, } \\
\text { fatigue, alopecia, } \\
\text { palmar plantar } \\
\text { erythrodysaesthesia } \\
\text { syndrome, and weight } \\
\text { reduction }\end{array}$ \\
\hline Cabozantinib & $\begin{array}{l}\text { Phase II trial, } \\
\text { Daud, A., et al. } \\
2017 \text { [181] }\end{array}$ & $\begin{array}{l}\text { Median age of } \\
65 \text { (range, } \\
\text { 30-90) years }\end{array}$ & 77 & 100 mg daily & $\begin{array}{l}\text { Median OS } \\
\text { and PFS = 9.4 } \\
\text { and } 3.8 \text { month, } \\
\text { respectively }\end{array}$ & 5 PRs & $\begin{array}{c}\text { The most common AEs } \\
\text { were grade } 3 / 4 \text { : } \\
\text { fatigue, hypertension, } \\
\text { and abdominal pain }\end{array}$ \\
\hline
\end{tabular}

Abbreviations: AE: adverse event; OS: overall survival; PFS: progression free survival; PR: partial response; CR: complete response.

\subsection{VEGFR}

Angiogenesis is mediated by a variety of signaling molecules; among these are the vascular endothelial growth factors (VEGFs) and receptors (VEGFRs). VEGF receptors are classified as type V RTKs. VEGFR1 is located on chromosome 13q12, VEGFR2 on chromosome 4q11-q12 [182], and the VEGFR3 gene is located on chromosome 5q35 [183]. VEGF receptors show structure homology but display interesting differences in their kinase activities and spectrum of transduced biological responses [184]. VEGFs ligands bind to three types of RTKs, VEGFR-1 (Flt-1), VEGFR-2 (KDR, Flk-1), and VEGFR-3 (Flt-4). The VEGF gene family encodes soluble glycosylated and released cytokines that form dimers: VEGFA, VEGF-B, VEGF-C, VEGF-D, VEGF-E and placenta growth factors (PlGF-1, PlGF-2) [185] A critical difference between VEGFR1 and VEGFR2 or VEGFR3 is that VEGF-A binds to VEGFR1 with a higher affinity, and the later shows a selective binding to VEGF-B and PIGF (placenta growth factor). Furthermore, VEGF-C and VEGF-D, highly specific for VEGFR3 and could bind to VEGF2. VEGFR2 and VEGFR3 are stronger kinases compared to VEGFR1, similar to other RTKs such as EGFR and PDGFR [2,186,187]. VEGFR-2 activates a broad signaling pathways and biological processes [188]. Both VEGFR-1 and VEGFR-2 are expressed by endothelial cells and could form heterodimers leading to autophosphorylation, activation of VEGFR-2, and angiogenesis [189]. Human VEGFR1 consists of 1338 amino acids, distributed in three major domains: an extracellular region consisting of seven immunoglobulin (Ig)-like domains, a transmembrane domain, a tyrosine kinase domain (70-amino acid residues), and a kinase insert region followed by a downstream C-terminal region. VEGFR2 (KDR in the human) composed of 1356 amino acids as well as VEGFR3 (also denoted Flt-4) are similarly organized and show $80 \%$ similarities to VEGFR1 in the tyrosine kinase domain (Figure 4A). The main difference with VEGFR3 is within the extracellular domain, by replacement of the fifth Ig-like loop by a disulfide bridge that keeps the proteolytically cleaved N-terminal part of the extracellular domain connected with the remainder of the molecule [190]. VEGFR1 and VEGFR2 ligands bind to the extracellular region to the second and third Ig-like domains and show symmetrical 2:2 complex structure (Figure 4B) $[186,191,192]$. The fourth Ig-like domain appears essential for VEGFR dimerization. Analysis of the VEGF/VEGFR-2 complex indicates that a dimeric VEGF ligand binds the Ig-like domains 2 and 3 of one receptor monomer and favors the possibility of a second receptor monomer to bind the already tethered ligand (ligand mediated dimerization). Once the two receptors are cross-linked through ligand simultaneous interaction, their Ig-like domain $7 \mathrm{~s}$ are held in close proximity to further stabilize the receptor dimers [193]. The intracellular domain contains two kinase domains named KD1 and 
KD2, which are split by a kinase-insert domain of 70 amino acids. Five tyrosine residues have been reported as major phosphorylation sites: Y951 (KID), Y1054 and Y1059 (ALP domain), and Y1175 and Y1214 (carboxyl terminus domain). Phosphorylation of these residues, together with the adjacent amino-acid sequence, mediate a docking site for the SH2 domains of various signaling molecules [188,194]. Particularly, phosphorylation of tyrosine residue 1214 plays a crucial role in the autophosphorylation and kinase activation of VEGFR-2. The intracellular regions of both VEGFR-1 and VEGFR-2 adopt a bilobal structure that is split by the kinase insert domain. The N-lobe of the kinase domain consists of antiparallel $\beta$-sheets and a single $\alpha$ helix denoted $\alpha \mathrm{C}$-helix. The reorientation of $\alpha \mathrm{C}$-helix is crucial to mediate the kinase switch. The active site of the enzyme is located in the cleft between the $\mathrm{N}$ - and the C-lobe. Activation of tyrosine kinases requires the phosphorylation of tyrosine residues on both the JMD and in the activation loop domain that causes the reorientation of $\alpha \mathrm{C}$-helix. In the open conformation, ATP and substrates bind to specific residues of the enzyme between the $\mathrm{N}$ - and the $\mathrm{C}$-lobe. Following activation, detachment of the $\gamma$-phosphate of ATP and its transfer to the substrate occurs in the closed conformation. ADP release and phosphorylated substrate occur in the transition from the closed to the open. The JMD of VEGFR-2 may show a similar mechanism previously found in type III RTKs. It was reported that receptor dimerization is important but not sufficient for receptor kinase activation that requires conformational changes in the TMD of VEGFR-2 on glutamic acid residues. Furthermore, it was shown that ECD of VEGFR-2 plays a critical role in maintaining the receptor in the inactive state in the absence of ligand. Moreover, during the activation process, the ECD promotes the correct TMD conformation, which culminates in the proper orientation of the intracellular kinase domains to favor receptor activation [195]. In contrast to TKRs that activate the MAPK or PI3K pathways, the PLC $\gamma$ PKC-MAPK pathway is highly activated in VEGF-bound VEGFR-2 and its crucial signal for endothelial proliferation and proangiogenic signaling [196]. In melanoma, high VEGF expression was associated with poor prognosis [197]. VEGFR-1 and VEGFR-2 expression and VEGF-A release were reported in several melanoma cells [198]. Immunohistochemical analysis, indicated that VEGF is expressed by most of primary melanomas $[199,200]$. It was indicated that over release of VEGF and upregulated VEGFR expression favors melanoma growth through MAP kinase and PI3K signaling pathways [201]. Additionally, high mRNA and protein expression of VEGF and other pro-angiogenic mediators were associated with poor melanoma patients outcome [202,203] supported by the higher VEGF and VEGFR-2 expression in metastatic compared to primary lesions. Moreover, upregulation of VEGFR-1 was evidenced as a mechanism of resistance to the mutant-BRAF inhibitor vemurafenib in human melanoma cells [204]. Therefore, targeting VEGFR/angiogenesis could be of particular clinical importance in melanoma and splits into two groups: multikinase inhibitors (oral small molecules) or more specific monoclonal antibodies [205]. Several preclinical and clinical studies targeting VEGFR were launched but we will only focus below on the first category.

\subsubsection{SU5416, Sugen (Semaxanib ${ }^{\mathrm{TM}}$ )}

Semaxinib (SU5416, Sugen) was the first designed Flk-1/KDR tyrosine kinase inhibitor tested in several clinical trials [206]. SU5416 is a potent, ATP-competitive inhibitor of the tyrosine kinase activity of mainly VEGFR2 that showed weaker activity against PDGFR (platelet-derived growth factor receptor) and FGFR (fibroblast growth factor receptor). Early studies indicate that SU5416 was effective in A375 human melanoma mouse model when administered twice weekly [207], but a phase II trial with SU5416 as a single agent in melanoma as well as in other malignancies failed to show efficacy (Table 10) [208]. Consequently, several studies examined the benefit of dual targeting of VEGF pathway by antagonizing both VEGF production and activation. A phase II trial evaluating the efficacy and toxicity of semaxanib and thalidomide (anti-angiogenesis) combination was launched but discontinued early due to the development of other second-generation 
VEGFR inhibitors. However, the study underlined the feasibility, potential efficacy and the importance of future dual angiogenic targeting in melanoma patients (Table 10) [209].

A

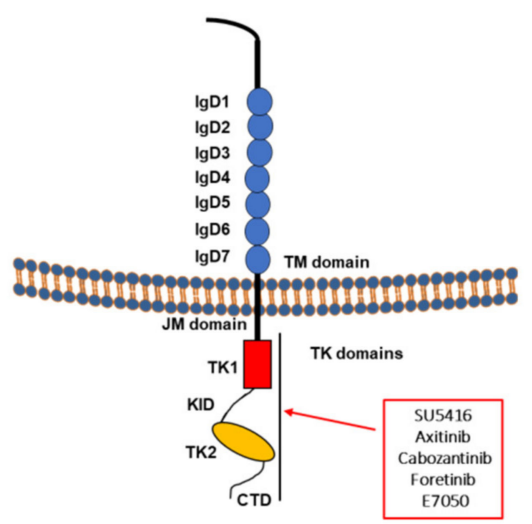

B

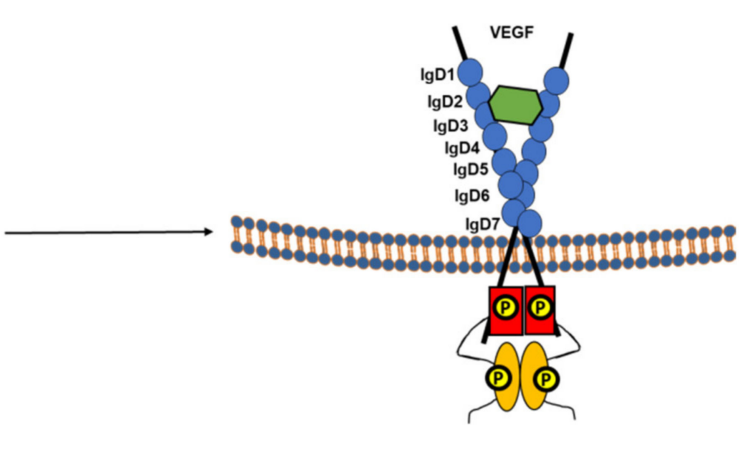

Figure 4. VEGFR structure and activation. (A) ECD of VEGFR is composed of a single peptide that consists of seven Ig-like subdomains (IgD1 7), transmembrane domain (TM), juxtamembrane domain (JM), tyrosine kinase 1 domain (TK1) including ATP binding domain, kinase insert domain (KID), tyrosine kinase 2 domain (TK2), and a flexible C-terminal domain (CTD). (B) VEGFs binding to VEGFR require two Ig-like subdomains 2 and 3 (IgD2 and IgD3), and the stabilization of dimers and VEGF-mediated activity required Ig-like subdomains $4 \sim 7$ (IgD4 7). This mediates tyrosine residues phosphorylation on the TKD and downstream signaling pathways activation. VEGFR-tyrosine kinase inhibitors occupy the ATP-binding pocket of the kinase domain to exhibit its inhibitory function.

\subsubsection{Axitinib (INLYTA ${ }^{\circledR}$ )}

Axitinib (AG-013736) is an oral, potent, and selective second-generation inhibitor of VEGFR-1, 2, and 3, first approved in renal cell carcinoma. It showed efficacy in preclinical and clinical studies including melanoma (Table 11) [210]. A phase II melanoma trial with axitinib alone indicated its safety and efficacy in metastatic melanoma, but suggested its use in combination with other treatment modalities (Table 10) [211] Thus, axitinib enhanced OVA peptide vaccine protector activity against melanoma (Table 11) [212]. A prospective, single-arm, phase II study of axitinib with carboplatin and paclitaxel showed a safe profile and favored disease control in advanced BRAF wild-type melanoma (Table 10) [213]. Furthermore, as a consequence of poor prognosis of stage III melanoma and the promising clinical reports of anti-angiogenesis compounds, a phase II trial evaluated axitinib effect in melanoma [214]. Furthermore, encouraging studies evaluating the benefit of axitinib combination with other treatment modalities such as toripalimab (anti-PD-1) in mucosal melanoma is underway (NCT04180995) [215].

Table 10. Melanoma clinical trials with VEGFR inhibitors.

\begin{tabular}{|c|c|c|c|c|c|c|c|}
\hline RTKi & $\begin{array}{l}\text { Phase/Year } \\
\text { Published or } \\
\text { Presented }\end{array}$ & $\begin{array}{c}\text { Study } \\
\text { Population }\end{array}$ & $\mathbf{N}$ & Dose & Survival & Response & Adverse Reactions \\
\hline $\begin{array}{l}\text { SU5416, } \\
\text { Semaxanib }\end{array}$ & $\begin{array}{l}\text { Phase II, } \\
\text { Kuenen, B.C., } \\
\text { et al. } 2003 \text { [208] }\end{array}$ & $\begin{array}{l}\text { Median age of } \\
53.5 \text { (range, } \\
23-71 \text { ) years }\end{array}$ & 20 & $\begin{array}{l}145 \mathrm{mg} \cdot \mathrm{m}^{-2} \\
\text { twice weekly }\end{array}$ & $\begin{array}{c}\text { Median OS and } \\
\text { PFS = } 107.5 \text { and } 41 \\
\text { days, } \\
\text { respectively. }\end{array}$ & $\begin{array}{l}\text { No } \\
\text { Response }\end{array}$ & $\begin{array}{l}\text { Main (AEs): headache, } \\
\text { phlebitis, nausea, } \\
\text { vomiting, anorexia, } \\
\text { diarrhea, and asthenia }\end{array}$ \\
\hline $\begin{array}{l}\text { SU5416 + } \\
\text { Thalidomide } \\
\text { (THAL) }\end{array}$ & $\begin{array}{l}\text { Phase II, Mita, } \\
\text { M.M., et al. } \\
\text { 2007 [209] }\end{array}$ & $\begin{array}{c}\text { Median age of } \\
58 \text { (range, } \\
43-71)\end{array}$ & 12 & $\begin{array}{c}\text { Semaxanib } \\
\left(145 \mathrm{mg} \cdot \mathrm{m}^{-2},\right. \\
\text { twice } / \text { week }+ \\
\text { THAL starting } \\
200 \mathrm{mg} / \mathrm{d}\end{array}$ & $\begin{array}{l}\text { Median survival }= \\
7.3 \text { months }\end{array}$ & $\begin{array}{l}\text { One } C R \text { and } \\
\text { one PR }\end{array}$ & $\begin{array}{c}\text { The common toxicities: } \\
\text { deep } \\
\text { venous, thrombosis, } \\
\text { headache, and lower } \\
\text { extremity edema }\end{array}$ \\
\hline
\end{tabular}


Table 10. Cont.

\begin{tabular}{|c|c|c|c|c|c|c|c|}
\hline RTKi & $\begin{array}{l}\text { Phase/Year } \\
\text { Published or } \\
\text { Presented }\end{array}$ & $\begin{array}{c}\text { Study } \\
\text { Population }\end{array}$ & $\mathbf{N}$ & Dose & Survival & Response & Adverse Reactions \\
\hline Axitinib & $\begin{array}{c}\text { Phase II, } \\
\text { Fruehauf, J. } \\
\text { et al. } 2011 \text { [211] }\end{array}$ & $\begin{array}{c}\text { Median age } 65 \\
\text { (range, } 30-86)\end{array}$ & 32 & $\begin{array}{c}5 \mathrm{mg} / \text { twice a } \\
\text { day }\end{array}$ & $\begin{array}{l}\text { Median OS and } \\
\text { PFS = } 6.6 \text { and } 3.9 \\
\text { months } \\
\text { respectively }\end{array}$ & $\begin{array}{l}\text { One CR and } \\
\text { five PRs }\end{array}$ & $\begin{array}{c}\text { The most common } \\
\text { (AE)s included fatigue, } \\
\text { hypertension, } \\
\text { hoarseness, diarrhea }\end{array}$ \\
\hline $\begin{array}{l}\text { Axitinib + } \\
\text { carboplation+ } \\
\text { paclitaxel }\end{array}$ & $\begin{array}{c}\text { Phase II, } \\
\text { Algazi, A.P., } \\
\text { et al. } 2015 \text { [213] }\end{array}$ & $\begin{array}{c}\text { Median age } \\
65.4 \text { years }\end{array}$ & 36 & $\begin{array}{c}\text { Axitinib } \\
5 \mathrm{mg} \text { PO b.i.d. } \\
+ \text { carboplatin } \\
(\text { AUC }=5) \text { with } \\
\text { paclitaxel }(175 \\
\left.\mathrm{mg} \cdot \mathrm{m}^{-2}\right)\end{array}$ & $\begin{array}{l}\text { Median OS and } \\
\text { PFS = } 14 \text { and } 8.7 \\
\text { months, } \\
\text { respectively }\end{array}$ & $\begin{array}{l}8 \text { patients } \\
\text { achieved } \\
\text { PRS }\end{array}$ & $\begin{array}{l}\text { The most common } \\
\text { (AE)s: hypertension, } \\
\text { neutropenia, and } \\
\text { anaemia }\end{array}$ \\
\hline $\begin{array}{l}\text { Bevacizumab } \\
\text { (Bevax) } \\
+ \\
\text { low-dose } \\
\text { interferon } \\
\text { alfa-2b }\end{array}$ & $\begin{array}{c}\text { Phase 2, Varker, } \\
\text { K.A., et al. } \\
2007 \text { [216] }\end{array}$ & $\begin{array}{l}\text { Median age } \\
57.5 \text { (range, } \\
28-83 \text { ) years }\end{array}$ & 32 & $\begin{array}{c}\text { Bevax } \\
(15 \mathrm{mg} / \mathrm{kg} \\
\text { every } 2 \text { weeks }) \\
+ \text { low-dose } \\
\text { IFN- } \alpha 2 \mathrm{~b} \\
\left(1 \mathrm{MU} \cdot \mathrm{m}^{-2}\right. \\
\text { daily) }\end{array}$ & $\begin{array}{l}\text { Median OS and } \\
\text { PFS = } 10 \text { and } 3 \\
\text { months } \\
\text { respectively }\end{array}$ & One PR & $\begin{array}{c}\text { The most }(\mathrm{AE}) \text { s were of } \\
\text { grade } 1 / 2 \text { : fatigue, } \\
\text { anorexia, myalgia, } \\
\text { headache, nausea, } \\
\text { vomiting }\end{array}$ \\
\hline $\begin{array}{l}\text { Bevacizumab } \\
\text { (Bevax) } \\
+ \text { high dose } \\
\text { interferon } \\
\text { alfa-2b }\end{array}$ & $\begin{array}{c}\text { Phase II, } \\
\text { Grignol, V.P., } \\
\text { et al. } 2011 \text { [217] }\end{array}$ & $\begin{array}{l}\text { Median age } \\
58.4 \text { (range, } \\
31-79) \text { years }\end{array}$ & 25 & $\begin{array}{c}\text { Bevax } 15 \\
\mathrm{mg} / \mathrm{kg}+ \\
5 \mathrm{MU} / \mathrm{m} \text { IFN- } \alpha \\
\text { thrice weekly }\end{array}$ & $\begin{array}{l}\text { Median OS and } \\
\text { PFS }=17 \text { and } 4.8 \\
\text { months } \\
\text { respectively }\end{array}$ & $\begin{array}{c}6 \text { PRs, and } 5 \\
\text { SD }\end{array}$ & $\begin{array}{c}\text { The common (AE)s } \\
\text { were fatigue, anorexia, } \\
\text { nausea/vomiting, } \\
\text { fever/chills, anemia }\end{array}$ \\
\hline $\begin{array}{l}\text { Bevacizumab } \\
(\text { Bevax })+ \\
\text { paclitaxel }+ \\
\text { carboplatin }\end{array}$ & $\begin{array}{l}\text { Phase II, Kim, } \\
\text { K.B., et al.2012 } \\
\text { [218] }\end{array}$ & $\begin{array}{l}\text { Median age } 60 \\
\text { (range, 27-85) } \\
\text { years }\end{array}$ & 143 & $\begin{array}{c}\text { Bevax (15 } \\
\text { mg/kg), } \\
\text { carboplatin } \\
\text { (area under the } \\
\text { curve, 5) plus } \\
\text { paclitaxel }(175 \\
\left.\mathrm{mg} \cdot \mathrm{m}^{-2}\right)\end{array}$ & $\begin{array}{c}\text { Median OS and } \\
\text { PFS = } 12.3 \text { and } 5.6 \\
\text { months, } \\
\text { respectively }\end{array}$ & $\begin{array}{c}3 \text { CRs and } 33 \\
\text { PRs }\end{array}$ & $\begin{array}{l}\text { The most common } \\
\text { (AE)s: neutropenia, } \\
\text { peripheral neuropathy, } \\
\text { febrile neutropenia, } \\
\text { arterial } \\
\text { thromboembolic events, } \\
\text { and hypertension }\end{array}$ \\
\hline Bevacizumab & $\begin{array}{c}\text { Phase III } \\
\text { Corrie, P.G., } \\
\text { et al. } 2018 \text { [219] }\end{array}$ & $\begin{array}{c}\text { Median age } 56 \\
\text { years (18-88 } \\
\text { years) }\end{array}$ & 671 & $7.5 \mathrm{mg} / \mathrm{kg}$ & $\begin{array}{c}\text { Median DFI }=63 \\
\text { months }\end{array}$ & $\begin{array}{l}\text { Adjuvant be- } \\
\text { vacizumab } \\
\text { improved } \\
\text { DFI but did } \\
\text { not improve } \\
\text { OS }\end{array}$ & $\begin{array}{c}\text { Common grade } 3 \text { or } 4 \\
\text { adverse events was } \\
\text { hypertension }\end{array}$ \\
\hline
\end{tabular}

Abbreviations: AE: adverse event; DFS: disease-free interval; OS: overall survival; PFS: progression free survival; PR: partial response; SD: stable disease.

Table 11. Preclinical studies evaluating VEGFR inhibitors in melanoma.

\begin{tabular}{|c|c|c|c|}
\hline RTKi & Cell Lines Used & Results & Literature \\
\hline Axitinib & $\begin{array}{l}\text { M24met }\left({ }^{61 R} \text { NRAS }\right), \\
\left.\text { A375 ( }{ }^{\mathrm{V} 600 \mathrm{E}} \text { BRAF }\right) \\
\left.\text { A2058 ( }{ }^{\mathrm{V} 600 \mathrm{E}} \text { BRAF }\right)\end{array}$ & $\begin{array}{l}\text {-Axitinib inhibited VEGFR-2 } \\
\text { phosphorylation and partially ERK1/2 } \\
\text { signal in angiogenic } \\
\text { vessels of xenograft tumors of M24 met. } \\
\text {-Axitinib in combination with } \\
\text { bevacizumab } \\
\text { inhibited lymph node metastasis and } \\
\text { prolonged survival. }\end{array}$ & Hu-Lowe, D.D., et al. 2008 [210] \\
\hline $\begin{array}{l}\text { Axitinib + OVA peptide-based } \\
\text { vaccination }\end{array}$ & MO5 (B16.OVA) & $\begin{array}{l}\text {-Axitinib enhances vaccine effect to } \\
\text { prevent melanoma growth and to favor } \\
\text { T cell infiltration and activity. } \\
\text {-This combination prevents } \\
\text { accumulation of MDSC and Treg } \\
\text { suppressor cells and promotes type-1 LT } \\
\text { cells function in vivo. }\end{array}$ & Bose, A., et al. 2012 [212] \\
\hline Bevacizumab & $\begin{array}{l}\text { A-07 and D-12 meningeal } \\
\text { human melanoma cells } \\
\text { inoculated in the intracranial } \\
\text { region of BALB/c nu/nu mice }\end{array}$ & $\begin{array}{l}\text {-Bevacizumab inhibits angiogenesis and, } \\
\text { increases cerebral invasion and genes } \\
\text { related angiogenesis expression of A-07 } \\
\text { tumors }\end{array}$ & Simonsen, T.G., et al. 2020 [220] \\
\hline
\end{tabular}




\section{Dual MET/HGF and VEGF/VEGFR Targeting}

Dysregulation of HGF and/or MET expression are both observed in several tumors including melanoma [176]. Additionally, angiogenesis regulated by VEGF/VEGFR axis is widely considered a crucial step in tumor progression. As result, targeting both signaling axis HGF/Met and VEGF/VEGFR could be efficient to disrupt tumorigenesis and cancer metastasis. Consequently, several TK inhibitors show dual inhibitory potential and were tested in melanoma.

\subsubsection{Cabozantinib (COMETRIQ ${ }^{\circledR}$ )}

Cabozantinib (XL184) is a dual MET/VEGFR2 inhibitor acting as an ATP-competitive inhibitor of MET, VEGFR2, TIE2, and FLT3 with activity against other targets such as RET, AXL, and c-KIT. In preclinical studies, cabozantinib treatment was shown to have activity against angiogenesis and cancer progression [221]. Cabozantinib is approved as a second line treatment of medullary thyroid (MTC) and renal cell (RCC) cancers [222]. In B16F10 mouse melanoma cells, cabozantinib inhibited invasion and migration mediated by HGF (Table 12) [221]. Additionally, due to its encouraging results in phase I trials in multiple cancer types, the limited efficiency of VEGFR inhibitors as montherapy [223], the involvement of MET in the resistance to vemurafenib in BRAF mutated melanoma [163,224] and the importance of a dual targeting of MET and VEGFR, a randomized phase II trial of cabozantinib in metastatic melanoma was launched and showed clinical benefit independent of BRAF mutation status but was discontinued because it was underpowered to draw conclusions (Table 9) [181]. Cabozantinib also showed immune-modulatory effect in several cancers. Therefore, several clinical trials are ongoing to test cabozantinib with immunotherapy in melanoma [225,226] (NCT03957551, NCT04091750).

\subsubsection{Foretinib (Exelixis, GlaxoSmithKline) (XL-880)}

Foretinib (GSK1363089) is an oral multikinase inhibitor targeting MET, RON, AXL, Tie2, VEGFR, c-KIT, Flt-3, and PDGFR signaling pathways. It was found particularly effective against gastric and renal cancer. Foretinib, has been also used as a first-line therapy in hepatocellular carcinoma, and HER2-positive (phase I) and triple-negative breast cancer (phase II) [120]. Foretinib acts by inhibiting HGF-induced MET phosphorylation, VEGFinduced phosphorylation and precludes both HGF-mediated responses of tumor cells and HGF/VEGF-stimulation [227]. In melanoma, foretinib inhibited HGF-induced cell migration and invasion, MET phosphorylation, tumor growth and lung metastases of B16F10 model. In addition, foretinib prevented in vitro endothelial tube formation in response to VEGF, suggesting an antivascular activity (Table 12) [228]. Additionally, it significantly affected melanoma cell viability in a dose-dependent manner, changed nuclei morphology, and accumulated cells in phase G2/M (Table 6) [120]. Foretinib combination with EGFR inhibitors synergistically decreased cell viability, invasion, and migration (Table 6) [120]. Like lapatinib, foretinib alone reduces migratory capacities, invasion, Src phosphorylation and invadopodia formation in melanoma. These activities are more pronounced when combined with an EGFR inhibitor (Table 6) [108].

Table 12. Dual VEGFR/MET inhibition in melanoma preclinical studies.

\begin{tabular}{|c|c|c|c|}
\hline RTKi & Cell Lines Used & Results & Literature \\
\hline Cabozantinib & Murine B16F10 cells & $\begin{array}{l}\text {-Cabozantinib inhibits cell tubule } \\
\text { formation, migration, and } \\
\text { invasion }\end{array}$ & $\begin{array}{l}\text { Yakes F et al. } 2011 \\
\text { [221] }\end{array}$ \\
\hline Foretinib & Murine B16F10 cells & $\begin{array}{l}\text {-Foretinib inhibits migration, } \\
\text { invasion, and anchorage } \\
\text { dependent growth. } \\
\text {-Foretinib inhibits } \\
\text { phosphorylation of Met, } \\
\text { Flk-1/KDR, and reduces tumor } \\
\text { burden injected in mice. }\end{array}$ & Qian F et al. 2009 [228] \\
\hline
\end{tabular}




\subsubsection{E7050}

E7050 (Eisai) is an oral, ATP-competitive, dual inhibitor of Met-VEGFR. It circumvented resistance to EGFR tyrosine kinase inhibitors by blocking the Met/Gab1/PI3K/Akt pathway in vitro [229]. A unique phase II clinical trial tested its combination with a VEGFR inhibitor (E7080) in advanced melanoma (NCT01433991) [230].

\subsection{Other RTKS}

\subsubsection{IGF1R}

The type 1 insulin-like growth factor receptor (IGF1R) is a class II transmembrane receptor tyrosine kinase (RTK) that regulates key functions in cell growth and differentiation. IGF1R is broadly expressed across many cell types in fetal and postnatal tissues. Binding of the secreted growth factor ligands IGF-1 and IGF-2 to the ECD of the receptor, activates various downstream cellular responses such cell proliferation, cell death prevention or apoptosis [231]. IGF1R dysregulation has been associated with several human diseases such growth retardation and cancers [232]. Elevated levels of IGFIR are described in a variety of tumor types, and the IGF-1 axis was shown to be a predisposing factor in the development of human breast and prostate cancer. Furthermore, it was reported that IGF1R expression correlates with melanoma progression [233], although early observation indicates the absence of IGF-1 expression in melanoma cells [234]. Later, a study indicated implication of IGF-1 in melanoma pathophysiology through activation of anti-apoptotic proteins Bcl-2 and Bcl-XL and surviving [235]. Few reports discussed and evaluated IGF1R inhibition in melanoma. However, recently, it was reported that phosphatase activity of PTEN increases IGF1R expression which enhances melanoma cells resistance to vemurafenib and targeting IGF1R could be useful in melanoma patients with PTEN-positive tumors to overcome therapy resistance [236].

\subsubsection{FGFR}

The human fibroblast growth factor receptor (FGFR) is a class IV transmembrane receptor tyrosine kinase. Similar to other RTKs, FGFRs are expressed on the cell membrane and can be activated following binding of FGF ligands to the ECD of the receptor. This mediates to FGFRs dimerization and subsequent, transautophosphorylation event of the intracellular kinase domain and activation of downstream transduction pathways, which regulates several physiological process such as proliferation, survival, differentiation, and cell migration $[2,237,238]$. Aberrant FGFRs expression has been shown in several solid malignancies such myeloma, bladder cancer, and non-small cell lung cancer and consequently, clinical drugs specifically targeting FGFs or FGF receptors were developed and tested in several diseases [238]. It was reported that an activating mutation of FGFR3 can augment the invasiveness of many tumors. As well, FGFR3 amplification or overexpression was shown to increase tumor progression [239]. In melanoma, FGFR1 regulates growth, angiogenesis, migration, and metastasis [240]. Additionally, FGFR2 promotes melanoma metastasis and recently, the implication of FGFR3 in melanoma growth, metastasis, and EMT behaviors was elucidated, through modulation of phosphorylation levels of ERK, AKT, and EGFR [241]. Furthermore, FGF/FGFR signaling contributes to intratumoral angiogenesis, melanoma survival and resistance to therapeutics [242]. Consequently, drugs targeting FGF/FGFR signaling are considered in combination treatment for melanoma patients showing resistance to (BRAF)/MEK inhibitors (ongoing LOGIC-2 phase II clinical trial [243]). The clinical trial testing FGFR inhibitor in melanoma is still ongoing and no published result indicates its efficiency in melanoma.

\section{RTK Inhibitors as Immune Modulators}

It was shown that RTK inhibitors may positively affect antitumor immunity. Indeed, it was reported that imatinib regulates immune cells involved in tumor immunosurveillance, boosts natural killer-cell-induced IFN $\alpha$ release and elicits antigen-specific T-cell responses that can prevent cancer relapses [244]. In addition, sunitinib is able to moderate regulatory 
$\mathrm{T}$ cells and thus increase T cells function [245]. In contrast, imatinib, dasatinib, or nilotinib, through off-target inhibition of kinases, can reduce memory B-cell activity that induces significant impairment of B-cell responses [246]. However, it was shown that imatinib and nilotinib exhibit variable effects on antitumor immunity, as both may impair differentiation of monocytes to DCs and reduce the activation of CD1a and CD83, but only nilotinib inhibits DC migration and consequently T-cell immune responses [247]. Thus, for future combinatory approaches, the most suitable KIT inhibitor deserves careful consideration. Additionally, EGFR inhibitors efficacy is not solely based on their direct effects on tumor cells, but also may act on the regulation of tumor microenvironment [248]. Particularly, cetuximab activates host anticancer immune response. Additionally, it was shown that EGFR inhibitors increase expression of class I and class II MHC molecules and influence adaptive immune response [249]. Furthermore, targeting EGFR could suppress T regs function, thus aiding and improving the efficacy of immunotherapy. In addition, RTK inhibitors, particularly sunitinib, pazopanib, sorafenib, and axitinib, also regulate immune effector cells activity and function. They reduce $\mathrm{T}$ cell proliferation, absolute neutrophils [250], monocytes [251], and lymphocyte T counts [245], causing related adverse events. Moreover, concomitant c-MET inhibition favors adoptive $\mathrm{T}$ cell transfer by increasing effector $\mathrm{T}$ cell infiltration in tumors [252]. Targeting c-Met impairs the recruitment of tumor-infiltrating neutrophils in response to immunotherapy [253]. Thus, targeting immunosuppressive cells enhances antitumor $\mathrm{T}$ cell response and warrants their combination with immunotherapy.

\section{RTK Inhibitors and Check-Point Inhibitors Combination}

The inhibition of PD-1 and PD-L1 axis achieved dramatic and durable responses in certain solid cancers such as melanoma, non-small cell lung cancer, and renal cell carcinoma. Combining immunotherapy with other treatment modalities is another approach to increase anti-tumor immunity through several mechanisms and is currently being tested in a number of clinical trials. In melanoma, several recent studies evaluated various targeted therapies, such as MAPK inhibitors in combination with immunotherapy, and are currently ongoing [254]. Additionally, combining EGFR antagonists to immunotherapy showed efficacy in a melanoma mouse model [248]. Interestingly, the treatment sequence is of importance as suggested by the finding that targeting angiogenesis (VEGFR inhibitor) followed by vaccination showed a better anti-tumor effect than the reverse [255]. It was also shown that treatment with anti-PD-1 nivolumab significantly prolonged OS compared to mTOR inhibitor (25.0 months vs. 19.6 months), among patients previously treated with antiangiogenic treatment. This benefit of nivolumab was observed in patients previously treated by pazopanib and not sunitinib [256], indicating that a specific targeting of VEGFR is behind such an effect. Furthermore, the HGF/MET pathway is one of the main mechanisms of resistance to anti-PD-1/PD-L1 immunotherapies, emphasizing the potential of MET-targeted therapies in PD-1/PD-L1 combinational strategies [252].

\section{Conclusions}

In BRAF-mutant melanoma, combining BRAF/MEK inhibitions and immune checkpoint blockade shows a synergistic and potentially safe response and is currently being investigated, taking drug resistance mechanisms into consideration. Conversely, in nonBRAF-mutated melanomas, novel combination strategies are still highly needed. In addition to NRAS mutations, several receptor tyrosine kinases (RTKs) such as c-KIT, EGFR, MET, and VEGFR have been reported to be involved in melanoma progression, invasion, or resistance to therapies, mainly targeting the MAPK pathway $[20,121,204]$. Several studies showed that BRAF V600 mutations developed resistance to BRAF or MEK inhibitors due to an up regulation of receptor tyrosine kinases such as VEGFR, MET, and/or EGFR [123]. On the other hand, up-regulation of MET and/or EGFR is one of the reported resistance mechanisms to BRAF/MEK inhibition. Consequently, the Foretinib and Afatinib combination is currently proposed in melanoma to overcome such resistance. Among c-KIT inhibitors, imatinib appears to display both efficacy and safety in melanoma. Additionally, the c-MET 
inhibitors crizotinib and cabozantinib showed the best clinical responses; particularly, cabozantinib as a dual MET-VEGFR inhibitor elicited particular immunomodulatory effects, making it a suitable partner for checkpoint inhibitors. Although targeting RTKs alone in melanoma did not show promise that is due to low compounds specificity, their major role in treatment escape mechanisms seems to be of a particular importance suggesting combination strategies that include RTK inhibition, particularly with check-point inhibitors. The major challenge for such an approach is depicting and understanding the associated mechanisms of action that vary from among the different melanoma subgroups.

Funding: This work has been supported by a grant from "Les Amis de l'Institut J. Bordet". Malak Sabbah is the recipient of a fellowship (Télévie grant No 7651819F).

Conflicts of Interest: The authors declare no conflict of interest.

\section{References}

1. Hedger, G.; Sansom, M.S.P.; Koldsø, H. The Juxtamembrane Regions of Human Receptor Tyrosine Kinases Exhibit Conserved Interaction Sites with Anionic Lipids. Sci. Rep. 2015, 5, 9198. [CrossRef]

2. Lemmon, M.A.; Schlessinger, J. Cell Signaling by Receptor Tyrosine Kinases. Cell 2010, 141, 1117-1134. [CrossRef] [PubMed]

3. Wintheiser, G.A.; Silberstein, P. Physiology, Tyrosine Kinase Receptors. In StatPearls; StatPearls Publishing: Treasure Island, FL, USA, 2019.

4. Du, Z.; Lovly, C.M. Mechanisms of Receptor Tyrosine Kinase Activation in Cancer. Mol. Cancer 2018, 17, 58. [CrossRef] [PubMed]

5. Braeuer, R.R.; Watson, I.R.; Wu, C.-J.; Mobley, A.K.; Kamiya, T.; Shoshan, E.; Bar-Eli, M. Why Is Melanoma so Metastatic? Pigment Cell Melanoma Res. 2014, 27, 19-36. [CrossRef] [PubMed]

6. McArthur, G.A.; Ribas, A. Targeting Oncogenic Drivers and the Immune System in Melanoma. J. Clin. Oncol. 2013, 31, 499-506. [CrossRef]

7. Akbani, R.; Kadir, C.; Aksoy, B.A.; Albert, M.; Ally, A.; Amin, S.B.; Arachchi, H.; Arora, A.J.; Auman, T.; Ayala, B.; et al. Genomic Classification of Cutaneous Melanoma. Cell 2015, 161, 1681-1696. [CrossRef]

8. Cheng, L.; Lopez-Beltran, A.; Massari, F.; MacLennan, G.T.; Montironi, R. Molecular Testing for BRAF Mutations to Inform Melanoma Treatment Decisions: A Move toward Precision Medicine. Mod. Pathol. 2018, 31, 24-38. [CrossRef]

9. Ribas, A.; Lawrence, D.; Atkinson, V.; Agarwal, S.; Miller, W.H.; Carlino, M.S.; Fisher, R.; Long, G.V.; Hodi, F.S.; Tsoi, J.; et al. Combined BRAF and MEK Inhibition with PD-1 Blockade Immunotherapy in BRAF-Mutant Melanoma. Nat. Med. 2019, 25, 936-940. [CrossRef]

10. Aasen, S.N.; Parajuli, H.; Hoang, T.; Feng, Z.; Stokke, K.; Wang, J.; Roy, K.; Bjerkvig, R.; Knappskog, S.; Thorsen, F. Effective Treatment of Metastatic Melanoma by Combining MAPK and PI3K Signaling Pathway Inhibitors. Int. J. Mol. Sci. 2019, 20, 4235. [CrossRef]

11. Muñoz-Couselo, E.; Adelantado, E.Z.; Ortiz, C.; García, J.S.; Perez-Garcia, J. NRAS-Mutant Melanoma: Current Challenges and Future Prospect. OncoTargets Ther. 2017, 10, 3941-3947. [CrossRef]

12. O'Bryan, J.P. Pharmacological Targeting of RAS: Recent Success with Direct Inhibitors. Pharmacol. Res. 2019, $139,503-511$. [CrossRef]

13. McKean, M.; Oba, J.; Ma, J.; Roth, K.G.; Wang, W.-L.; Macedo, M.P.; Carapeto, F.C.L.; Haydu, L.E.; Siroy, A.E.; Vo, P.; et al. Tyrosine Kinase Inhibitor and Immune Checkpoint Inhibitor Responses in KIT-Mutant Metastatic Melanoma. J. Investig. Dermatol. 2019, 139, 728-731. [CrossRef]

14. Newell, F.; Kong, Y.; Wilmott, J.S.; Johansson, P.A.; Ferguson, P.M.; Cui, C.; Li, Z.; Kazakoff, S.H.; Burke, H.; Dodds, T.J.; et al. Whole-Genome Landscape of Mucosal Melanoma Reveals Diverse Drivers and Therapeutic Targets. Nat. Commun. 2019, 10. [CrossRef]

15. D'Angelo, S.P.; Larkin, J.; Sosman, J.A.; Lebbé, C.; Brady, B.; Neyns, B.; Schmidt, H.; Hassel, J.C.; Hodi, F.S.; Lorigan, P.; et al. Efficacy and Safety of Nivolumab Alone or in Combination with Ipilimumab in Patients With Mucosal Melanoma: A Pooled Analysis. J. Clin. Oncol. 2017, 35, 226-235. [CrossRef] [PubMed]

16. Hintzsche, J.D.; Gorden, N.T.; Amato, C.M.; Kim, J.; Wuensch, K.E.; Robinson, S.E.; Applegate, A.J.; Couts, K.L.; Medina, T.M.; Wells, K.R.; et al. Whole-Exome Sequencing Identifies Recurrent SF3B1 R625 Mutation and Comutation of NF1 and KIT in Mucosal Melanoma. Melanoma Res. 2017, 27, 189-199. [CrossRef] [PubMed]

17. Lyu, J.; Song, Z.; Chen, J.; Shepard, M.J.; Song, H.; Ren, G.; Li, Z.; Guo, W.; Zhuang, Z.; Shi, Y. Whole-Exome Sequencing of Oral Mucosal Melanoma Reveals Mutational Profile and Therapeutic Targets. J. Pathol. 2018, 244, 358-366. [CrossRef] [PubMed]

18. Hayward, N.K.; Wilmott, J.S.; Waddell, N.; Johansson, P.A.; Field, M.A.; Nones, K.; Patch, A.-M.; Kakavand, H.; Alexandrov, L.B.; Burke, H.; et al. Whole-Genome Landscapes of Major Melanoma Subtypes. Nature 2017, 545, 175-180. [CrossRef] [PubMed]

19. Tworkoski, K.; Singhal, G.; Szpakowski, S.; Zito, C.I.; Bacchiocchi, A.; Muthusamy, V.; Bosenberg, M.; Krauthammer, M.; Halaban, R.; Stern, D.F. Phospho-Proteomic Screen Identifies Potential Therapeutic Targets in Melanoma. Mol. Cancer Res. 2011, 9, 801-812. [CrossRef] [PubMed] 
20. Sun, C.; Wang, L.; Huang, S.; Heynen, G.J.J.E.; Prahallad, A.; Robert, C.; Haanen, J.; Blank, C.; Wesseling, J.; Willems, S.M.; et al. Reversible and Adaptive Resistance to BRAF(V600E) Inhibition in Melanoma. Nature 2014, 508, 118-122. [CrossRef] [PubMed]

21. Li, F.Z.; Dhillon, A.S.; Anderson, R.L.; McArthur, G.; Ferrao, P.T. Phenotype Switching in Melanoma: Implications for Progression and Therapy. Front. Oncol. 2015, 5. [CrossRef] [PubMed]

22. Albanesi, C.; Geremia, R.; Giorgio, M.; Dolci, S.; Sette, C.; Rossi, P. A Cell- and Developmental Stage-Specific Promoter Drives the Expression of a Truncated c-Kit Protein during Mouse Spermatid Elongation. Development 1996, 122, 1291-1302. [PubMed]

23. Roskoski, R. Structure and Regulation of Kit Protein-Tyrosine Kinase-The Stem Cell Factor Receptor. Biochem. Biophys. Res. Commun. 2005, 338, 1307-1315. [CrossRef]

24. Roskoski, R. Signaling by Kit Protein-Tyrosine Kinase-The Stem Cell Factor Receptor. Biochem. Biophys. Res. Commun. 2005, 337, 1-13. [CrossRef] [PubMed]

25. Kitamura, Y.; Hirotab, S. Kit as a Human Oncogenic Tyrosine Kinase. Cell. Mol. Life Sci. 2004, 61, 2924-2931. [CrossRef] [PubMed]

26. Heinrich, M.C.; Blanke, C.D.; Druker, B.J.; Corless, C.L. Inhibition of KIT Tyrosine Kinase Activity: A Novel Molecular Approach to the Treatment of KIT-Positive Malignancies. J. Clin. Oncol. 2002, 20, 1692-1703. [CrossRef] [PubMed]

27. Shen, H.; Tang, Y.; Yang, S.; Qian, B.; Song, H.; Shi, S.; Xu, W. Analysis of CD117 expression on leukemia cells. Zhonghua Xue Ye Xue Za Zhi 2003, 24, 228-230.

28. Duensing, A.; Medeiros, F.; McConarty, B.; Joseph, N.E.; Panigrahy, D.; Singer, S.; Fletcher, C.D.M.; Demetri, G.D.; Fletcher, J.A. Mechanisms of Oncogenic KIT Signal Transduction in Primary Gastrointestinal Stromal Tumors (GISTs). Oncogene 2004, 23, 3999-4006. [CrossRef]

29. Tzen, C.-Y.; Wu, Y.-H.; Tzen, C.-Y. Characterization of KIT Mutation in Melanoma. Dermatol. Sin. 2014, 32, 7-12. [CrossRef]

30. Conca, E.; Negri, T.; Gronchi, A.; Fumagalli, E.; Tamborini, E.; Pavan, G.M.; Fermeglia, M.; Pierotti, M.A.; Pricl, S.; Pilotti, S. Activate and Resist: L576P-KIT in GIST. Mol. Cancer Ther. 2009, 8, 2491-2495. [CrossRef]

31. Carvajal, R.D.; Antonescu, C.R.; Wolchok, J.D.; Chapman, P.B.; Roman, R.-A.; Teitcher, J.; Panageas, K.S.; Busam, K.J.; Chmielowski, B.; Lutzky, J.; et al. KIT as a Therapeutic Target in Metastatic Melanoma. JAMA 2011, 305, 2327-2334. [CrossRef]

32. Hodi, F.S.; Corless, C.L.; Giobbie-Hurder, A.; Fletcher, J.A.; Zhu, M.; Marino-Enriquez, A.; Friedlander, P.; Gonzalez, R.; Weber, J.S.; Gajewski, T.F.; et al. Imatinib for Melanomas Harboring Mutationally Activated or Amplified KIT Arising on Mucosal, Acral, and Chronically Sun-Damaged Skin. J. Clin. Oncol. 2013, 31, 3182-3190. [CrossRef] [PubMed]

33. Chris, H.; Takimoto, M.D. Principles of Oncologic Pharmacotherapy. Available online: https://www.cancernetwork.com/ articles / principles-oncologic-pharmacotherapy (accessed on 25 March 2020).

34. Potti, A.; Hille, R.C.; Koch, M. Immunohistochemical Determination of HER-2/Neu Overexpression in Malignant Melanoma Reveals No Prognostic Value, While c-Kit (CD117) Overexpression Exhibits Potential Therapeutic Implications. J. Carcinog. 2003, 2, 8. [CrossRef] [PubMed]

35. Druker, B.J.; Talpaz, M.; Resta, D.J.; Peng, B.; Buchdunger, E.; Ford, J.M.; Lydon, N.B.; Kantarjian, H.; Capdeville, R.; Ohno-Jones, S.; et al. Efficacy and Safety of a Specific Inhibitor of the BCR-ABL Tyrosine Kinase in Chronic Myeloid Leukemia. N. Engl. J. Med. 2001, 344, 1031-1037. [CrossRef] [PubMed]

36. Van Oosterom, A.T.; Judson, I.; Verweij, J.; Stroobants, S.; Donato di Paola, E.; Dimitrijevic, S.; Martens, M.; Webb, A.; Sciot, R.; Van Glabbeke, M.; et al. Safety and Efficacy of Imatinib (STI571) in Metastatic Gastrointestinal Stromal Tumours: A Phase I Study. Lancet 2001, 358, 1421-1423. [CrossRef]

37. McGary, E.C.; Onn, A.; Mills, L.; Heimberger, A.; Eton, O.; Thomas, G.W.; Shtivelband, M.; Bar-Eli, M. Imatinib Mesylate Inhibits Platelet-Derived Growth Factor Receptor Phosphorylation of Melanoma Cells but Does Not Affect Tumorigenicity in Vivo. J. Investig. Dermatol. 2004, 122, 400-405. [CrossRef]

38. Redondo, P.; Lloret, P.; Andreu, E.J.; Inoges, S. Imatinib Mesylate in Cutaneous Melanoma. J. Investig. Dermatol. 2004, 123, 1208-1209. [CrossRef] [PubMed]

39. Ugurel, S.; Hildenbrand, R.; Zimpfer, A.; Rosée, P.L.; Paschka, P.; Sucker, A.; Keikavoussi, P.; Becker, J.C.; Rittgen, W.; Hochhaus, A.; et al. Lack of Clinical Efficacy of Imatinib in Metastatic Melanoma. Br. J. Cancer 2005, 92, 1398-1405. [CrossRef] [PubMed]

40. Kantarjian, H.; Sawyers, C.; Hochhaus, A.; Guilhot, F.; Schiffer, C.; Gambacorti-Passerini, C.; Niederwieser, D.; Resta, D.; Capdeville, R.; Zoellner, U.; et al. Hematologic and Cytogenetic Responses to Imatinib Mesylate in Chronic Myelogenous Leukemia. N. Engl. J. Med. 2002, 346, 645-652. [CrossRef]

41. Wyman, K.; Atkins, M.B.; Prieto, V.; Eton, O.; McDermott, D.F.; Hubbard, F.; Byrnes, C.; Sanders, K.; Sosman, J.A. Multicenter Phase II Trial of High-Dose Imatinib Mesylate in Metastatic Melanoma: Significant Toxicity with No Clinical Efficacy. Cancer 2006, 106, 2005-2011. [CrossRef] [PubMed]

42. Kim, K.B.; Eton, O.; Davis, D.W.; Frazier, M.L.; McConkey, D.J.; Diwan, A.H.; Papadopoulos, N.E.; Bedikian, A.Y.; Camacho, L.H.; Ross, M.I.; et al. Phase II Trial of Imatinib Mesylate in Patients with Metastatic Melanoma. Br. J. Cancer 2008, 99, 734-740. [CrossRef]

43. Curtin, J.A.; Busam, K.; Pinkel, D.; Bastian, B.C. Somatic Activation of KIT in Distinct Subtypes of Melanoma. J. Clin. Oncol. 2006, 24, 4340-4346. [CrossRef]

44. Jiang, X.; Zhou, J.; Yuen, N.K.; Corless, C.L.; Heinrich, M.C.; Fletcher, J.A.; Demetri, G.D.; Widlund, H.R.; Fisher, D.E.; Hodi, F.S. Imatinib Targeting of KIT-Mutant Oncoprotein in Melanoma. Clin. Cancer Res. 2008, 14, 7726-7732. [CrossRef] [PubMed] 
45. Guo, J.; Si, L.; Kong, Y.; Flaherty, K.T.; Xu, X.; Zhu, Y.; Corless, C.L.; Li, L.; Li, H.; Sheng, X.; et al. Phase II, Open-Label, Single-Arm Trial of Imatinib Mesylate in Patients with Metastatic Melanoma Harboring c-Kit Mutation or Amplification. J. Clin. Oncol. 2011, 29, 2904-2909. [CrossRef]

46. Rapisuwon, S.; Parks, K.; Al-Refaie, W.; Atkins, M.B. Novel Somatic KIT Exon 8 Mutation with Dramatic Response to Imatinib in a Patient with Mucosal Melanoma: A Case Report. Melanoma Res. 2014, 24, 509-511. [CrossRef]

47. Kim, K.B.; Alrwas, A. Treatment of KIT-Mutated Metastatic Mucosal Melanoma. Chin. Clin. Oncol. 2014, 3, 35. [CrossRef] [PubMed]

48. Flaherty, K.T.; Hamilton, B.K.; Rosen, M.A.; Amaravadi, R.K.; Schuchter, L.M.; Gallagher, M.; Chen, H.; Sehgal, C.; O’Dwyer, P.J. Phase I/II Trial of Imatinib and Bevacizumab in Patients with Advanced Melanoma and Other Advanced Cancers. Oncologist 2015, 20, 952-959. [CrossRef] [PubMed]

49. Wang, H.; Cheng, F.; Cuenca, A.; Horna, P.; Zheng, Z.; Bhalla, K.; Sotomayor, E.M. Imatinib Mesylate (STI-571) Enhances Antigen-Presenting Cell Function and Overcomes Tumor-Induced CD4+ T-Cell Tolerance. Blood 2005, 105, 1135-1143. [CrossRef]

50. Reilley, M.J.; Bailey, A.; Subbiah, V.; Janku, F.; Naing, A.; Falchook, G.; Karp, D.; Piha-Paul, S.; Tsimberidou, A.; Fu, S.; et al. Phase I Clinical Trial of Combination Imatinib and Ipilimumab in Patients with Advanced Malignancies. J. Immunother. Cancer 2017, 5 , 35. [CrossRef] [PubMed]

51. Fecher, L.A.; Nathanson, K.; Flaherty, K.T.; Amaravadi, R.; Giles, L.; McGettigan, S.; Carberry, M.; Elder, D.; Schuchter, L. Phase I/II Trial of Imatinib and Temozolomide in Advanced Unresectable Melanoma. JCO 2008, 26, 9059. [CrossRef]

52. Pembrolizumab and Imatinib in Patients With Locally Advanced/Metastatic Melanoma With c-KIT Mutation/Amplification-Full Text View-ClinicalTrials.Gov. Available online: https:/ / clinicaltrials.gov/ct2/show / NCT02812693 (accessed on 21 April 2020).

53. Abdou, Y.; Kapoor, A.; Hamad, L.; Ernstoff, M.S. Combination of Pembrolizumab and Imatinib in a Patient with Double KIT Mutant Melanoma. Medicine 2019, 98. [CrossRef]

54. Wei, X.; Mao, L.; Chi, Z.; Sheng, X.; Cui, C.; Kong, Y.; Dai, J.; Wang, X.; Li, S.; Tang, B.; et al. Efficacy Evaluation of Imatinib for the Treatment of Melanoma: Evidence from a Retrospective Study. Oncol. Res. 2019, 27, 495-501. [CrossRef]

55. Todd, J.R.; Becker, T.M.; Kefford, R.F.; Rizos, H. Secondary C-Kit Mutations Confer Acquired Resistance to RTK Inhibitors in c-Kit Mutant Melanoma Cells. Pigment Cell Melanoma Res. 2013, 26, 518-526. [CrossRef] [PubMed]

56. Delyon, J.; Chevret, S.; Jouary, T.; Dalac, S.; Dalle, S.; Guillot, B.; Arnault, J.-P.; Avril, M.-F.; Bedane, C.; Bens, G.; et al. STAT3 Mediates Nilotinib Response in KIT-Altered Melanoma: A Phase II Multicenter Trial of the French Skin Cancer Network. J. Investig. Dermatol. 2018, 138, 58-67. [CrossRef] [PubMed]

57. Eustace, A.J.; Crown, J.; Clynes, M.; O’Donovan, N. Preclinical Evaluation of Dasatinib, a Potent Src Kinase Inhibitor, in Melanoma Cell Lines. J. Transl. Med. 2008, 6, 53. [CrossRef] [PubMed]

58. Buettner, R.; Mesa, T.; Vultur, A.; Lee, F.; Jove, R. Inhibition of Src Family Kinases with Dasatinib Blocks Migration and Invasion of Human Melanoma Cells. Mol. Cancer Res. 2008, 6, 1766-1774. [CrossRef]

59. Woodman, S.E.; Trent, J.C.; Stemke-Hale, K.; Lazar, A.J.; Pricl, S.; Pavan, G.M.; Fermeglia, M.; Gopal, Y.N.V.; Yang, D.; Podoloff, D.A.; et al. Activity of Dasatinib Against L576P KIT Mutant Melanoma: Molecular, Cellular and Clinical Correlates. Mol. Cancer Ther. 2009, 8, 2079-2085. [CrossRef] [PubMed]

60. Homsi, J.; Cubitt, C.L.; Zhang, S.; Munster, P.N.; Yu, H.; Sullivan, D.M.; Jove, R.; Messina, J.L.; Daud, A.I. Src Activation in Melanoma and Src Inhibitors as Therapeutic Agents in Melanoma. Melanoma Res. 2009, 19, 167-175. [CrossRef]

61. Wu, J.; Liao, X.; Yu, B.; Su, B. Dasatinib Inhibits Primary Melanoma Cell Proliferation through Morphology-Dependent Disruption of Src-ERK Signaling. Oncol. Lett. 2013, 5, 527-532. [CrossRef]

62. Eustace, A.J.; Kennedy, S.; Larkin, A.-M.; Mahgoub, T.; Tryfonopoulos, D.; O’Driscoll, L.; Clynes, M.; Crown, J.; O’Donovan, N. Predictive Biomarkers for Dasatinib Treatment in Melanoma. Oncoscience 2014, 1, 158-166. [CrossRef]

63. Karwaciak, I.; Sałkowska, A.; Karaś, K.; Sobalska-Kwapis, M.; Walczak-Drzewiecka, A.; Pułaski, Ł.; Strapagiel, D.; Dastych, J.; Ratajewski, M. SIRT2 Contributes to the Resistance of Melanoma Cells to the Multikinase Inhibitor Dasatinib. Cancers $2019,11$. [CrossRef]

64. Gaustad, J.-V.; Simonsen, T.G.; Leinaas, M.N.; Rofstad, E.K. Sunitinib Treatment Does Not Improve Blood Supply but Induces Hypoxia in Human Melanoma Xenografts. BMC Cancer 2012, 12, 388. [CrossRef] [PubMed]

65. Gaustad, J.-V.; Pozdniakova, V.; Hompland, T.; Simonsen, T.G.; Rofstad, E.K. Magnetic Resonance Imaging Identifies Early Effects of Sunitinib Treatment in Human Melanoma Xenografts. J. Exp. Clin. Cancer Res. 2013, 32, 93. [CrossRef] [PubMed]

66. Han, Y.; Gu, Z.; Wu, J.; Huang, X.; Zhou, R.; Shi, C.; Tao, W.; Wang, L.; Wang, Y.; Zhou, G.; et al. Repurposing Ponatinib as a Potent Agent against KIT Mutant Melanomas. Theranostics 2019, 9, 1952-1964. [CrossRef] [PubMed]

67. Cullinane, C.; Natoli, A.; Hui, Y.; Conus, N.; Jackson, S.; Brüggen, J.; Manley, P.W.; McArthur, G.A. Preclinical Evaluation of Nilotinib Efficacy in an Imatinib-Resistant KIT-Driven Tumor Model. Mol. Cancer Ther. 2010, 9, 1461-1468. [CrossRef]

68. Cho, J.H.; Kim, K.M.; Kwon, M.; Kim, J.H.; Lee, J. Nilotinib in Patients with Metastatic Melanoma Harboring KIT Gene Aberration. Investig. New Drugs 2012, 30, 2008-2014. [CrossRef] [PubMed]

69. Carvajal, R.D.; Lawrence, D.P.; Weber, J.S.; Gajewski, T.F.; Gonzalez, R.; Lutzky, J.; O’Day, S.J.; Hamid, O.; Wolchok, J.D.; Chapman, P.B.; et al. Phase II Study of Nilotinib in Melanoma Harboring KIT Alterations Following Progression to Prior KIT Inhibition. Clin. Cancer Res. 2015, 21, 2289-2296. [CrossRef] 
70. Lee, S.J.; Kim, T.M.; Kim, Y.J.; Jang, K.-T.; Lee, H.J.; Lee, S.N.; Ahn, M.S.; Hwang, I.G.; Lee, S.; Lee, M.-H.; et al. Phase II Trial of Nilotinib in Patients with Metastatic Malignant Melanoma Harboring KIT Gene Aberration: A Multicenter Trial of Korean Cancer Study Group (UN10-06). Oncologist 2015, 20, 1312-1319. [CrossRef]

71. Guo, J.; Carvajal, R.D.; Dummer, R.; Hauschild, A.; Daud, A.; Bastian, B.C.; Markovic, S.N.; Queirolo, P.; Arance, A.; Berking, C.; et al. Efficacy and Safety of Nilotinib in Patients with KIT-Mutated Metastatic or Inoperable Melanoma: Final Results from the Global, Single-Arm, Phase II TEAM Trial. Ann. Oncol. 2017, 28, 1380-1387. [CrossRef]

72. Successful Treatment with Imatinib after Nilotinib and Ipilimumab in a C-Kit-Mutated Advanced Melanoma Patient: A Case Report.-PubMed-NCBI. Available online: https:/ / www.ncbi.nlm.nih.gov/pubmed/28410286 (accessed on 15 January 2020).

73. Dasatinib. LiverTox: Clinical and Research Information on Drug-Induced Liver Injury; National Institute of Diabetes and Digestive and Kidney Diseases: Bethesda, MD, USA, 2012.

74. Algazi, A.P.; Weber, J.S.; Andrews, S.C.; Urbas, P.; Munster, P.N.; DeConti, R.C.; Hwang, J.; Sondak, V.K.; Messina, J.L.; McCalmont, T.; et al. Phase I Clinical Trial of the Src Inhibitor Dasatinib with Dacarbazine in Metastatic Melanoma. Br. J. Cancer 2012, 106, 85-91. [CrossRef]

75. Kluger, H.M.; Dudek, A.Z.; McCann, C.; Ritacco, J.; Southard, N.; Jilaveanu, L.B.; Molinaro, A.; Sznol, M. A Phase II Trial of Dasatinib in Advanced Melanoma. Cancer 2011, 117, 2202-2208. [CrossRef]

76. Kalinsky, K.; Lee, S.; Rubin, K.; Lawrence, D.P.; Iafrarte, A.J.; Borger, D.R.; Margolin, K.A.; Leitao, M.M.; Tarhini, A.A.; Koon, H.B.; et al. A Phase II Trial of Dasatinib in Patients with Locally Advanced or Stage IV Mucosal, Acral and Vulvovaginal Melanoma: A Trial of the ECOG-ACRIN Cancer Research Group (E2607). Cancer 2017, 123, 2688-2697. [CrossRef]

77. Skoko, J.; Rožanc, J.; Charles, E.M.; Alexopoulos, L.G.; Rehm, M. Post-Treatment de-Phosphorylation of P53 Correlates with Dasatinib Responsiveness in Malignant Melanoma. BMC Cell Biol. 2018, 19. [CrossRef] [PubMed]

78. Imbulgoda, A.; Heng, D.Y.C.; Kollmannsberger, C. Sunitinib in the Treatment of Advanced Solid Tumors. Recent Results Cancer Res. 2014, 201, 165-184. [CrossRef] [PubMed]

79. Demetri, G.D.; van Oosterom, A.T.; Garrett, C.R.; Blackstein, M.E.; Shah, M.H.; Verweij, J.; McArthur, G.; Judson, I.R.; Heinrich, M.C.; Morgan, J.A.; et al. Efficacy and Safety of Sunitinib in Patients with Advanced Gastrointestinal Stromal Tumour after Failure of Imatinib: A Randomised Controlled Trial. Lancet 2006, 368, 1329-1338. [CrossRef]

80. Motzer, R.J.; Hutson, T.E.; Tomczak, P.; Michaelson, M.D.; Bukowski, R.M.; Oudard, S.; Negrier, S.; Szczylik, C.; Pili, R.; Bjarnason, G.A.; et al. Overall Survival and Updated Results for Sunitinib Compared with Interferon Alfa in Patients with Metastatic Renal Cell Carcinoma. J. Clin. Oncol. 2009, 27, 3584-3590. [CrossRef]

81. Minor, D.R.; Kashani-Sabet, M.; Garrido, M.; O’Day, S.J.; Hamid, O.; Bastian, B.C. Sunitinib Therapy for Melanoma Patients with KIT Mutations. Clin. Cancer Res. 2012, 18, 1457-1463. [CrossRef] [PubMed]

82. Decoster, L.; Vande Broek, I.; Neyns, B.; Majois, F.; Baurain, J.F.; Rottey, S.; Rorive, A.; Anckaert, E.; De Mey, J.; De Brakeleer, S.; et al. Biomarker Analysis in a Phase II Study of Sunitinib in Patients with Advanced Melanoma. Anticancer Res. 2015, 35, 6893-6899. [PubMed]

83. Buchbinder, E.I.; Sosman, J.A.; Lawrence, D.P.; McDermott, D.F.; Ramaiya, N.H.; Van den Abbeele, A.D.; Linette, G.P.; GiobbieHurder, A.; Hodi, F.S. Phase 2 Study of Sunitinib in Patients with Metastatic Mucosal or Acral Melanoma. Cancer 2015, 121, 4007-4015. [CrossRef]

84. Lamb, Y.N. Pexidartinib: First Approval. Drugs 2019, 79, 1805-1812. [CrossRef]

85. A Study of PLX3397 in Patients with Unresectable or Metastatic KIT-Mutated Melanoma-Full Text View-ClinicalTrials.Gov. Available online: https:/ / clinicaltrials.gov/ct2/show /NCT02975700 (accessed on 16 April 2020).

86. Tan, F.H.; Putoczki, T.L.; Stylli, S.S.; Luwor, R.B. Ponatinib: A Novel Multi-Tyrosine Kinase Inhibitor against Human Malignancies. OncoTargets Ther. 2019, 12, 635-645. [CrossRef]

87. Eisen, T.; Ahmad, T.; Flaherty, K.T.; Gore, M.; Kaye, S.; Marais, R.; Gibbens, I.; Hackett, S.; James, M.; Schuchter, L.M.; et al. Sorafenib in Advanced Melanoma: A Phase II Randomised Discontinuation Trial Analysis. Br. J. Cancer 2006, 95, 581-586. [CrossRef]

88. Huse, M.; Kuriyan, J. The Conformational Plasticity of Protein Kinases. Cell 2002, 109, 275-282. [CrossRef]

89. Vajpai, N.; Strauss, A.; Fendrich, G.; Cowan-Jacob, S.W.; Manley, P.W.; Grzesiek, S.; Jahnke, W. Solution Conformations and Dynamics of ABL Kinase-Inhibitor Complexes Determined by NMR Substantiate the Different Binding Modes of Imatinib/Nilotinib and Dasatinib. J. Biol. Chem. 2008, 283, 18292-18302. [CrossRef] [PubMed]

90. Schlessinger, J. Ligand-Induced, Receptor-Mediated Dimerization and Activation of EGF Receptor. Cell 2002, 110, 669-672. [CrossRef]

91. Wells, A. EGF Receptor. Int. J. Biochem. Cell Biol. 1999, 31, 637-643. [CrossRef]

92. Macdonald-Obermann, J.L.; Pike, L.J. Different Epidermal Growth Factor (EGF) Receptor Ligands Show Distinct Kinetics and Biased or Partial Agonism for Homodimer and Heterodimer Formation. J. Biol. Chem. 2014, 289, 26178-26188. [CrossRef]

93. Wilson, K.J.; Mill, C.; Lambert, S.; Buchman, J.; Wilson, T.R.; Hernandez-Gordillo, V.; Gallo, R.M.; Ades, L.M.C.; Settleman, J.; Riese, D.J. EGFR Ligands Exhibit Functional Differences in Models of Paracrine and Autocrine Signaling. Growth Factors 2012, 30, 107-116. [CrossRef]

94. Landau, M.; Fleishman, S.J.; Ben-Tal, N. A Putative Mechanism for Downregulation of the Catalytic Activity of the EGF Receptor via Direct Contact between Its Kinase and C-Terminal Domains. Structure 2004, 12, 2265-2275. [CrossRef] 
95. Zhang, X.; Gureasko, J.; Shen, K.; Cole, P.A.; Kuriyan, J. An Allosteric Mechanism for Activation of the Kinase Domain of Epidermal Growth Factor Receptor. Cell 2006, 125, 1137-1149. [CrossRef]

96. Jura, N.; Endres, N.F.; Engel, K.; Deindl, S.; Das, R.; Lamers, M.H.; Wemmer, D.E.; Zhang, X.; Kuriyan, J. Mechanism for Activation of the EGF Receptor Catalytic Domain by the Juxtamembrane Segment. Cell 2009, 137, 1293. [CrossRef]

97. Yarden, Y.; Sliwkowski, M.X. Untangling the ErbB Signalling Network. Nat. Rev. Mol. Cell Biol. 2001, 2, 127-137. [CrossRef]

98. Fleishman, S.J.; Schlessinger, J.; Ben-Tal, N. A Putative Molecular-Activation Switch in the Transmembrane Domain of ErbB2. Proc. Natl. Acad. Sci. USA 2002, 99, 15937-15940. [CrossRef]

99. Moriki, T.; Maruyama, H.; Maruyama, I.N. Activation of Preformed EGF Receptor Dimers by Ligand-Induced Rotation of the Transmembrane Domain. J. Mol. Biol. 2001, 311, 1011-1026. [CrossRef]

100. Burgess, A.W.; Cho, H.-S.; Eigenbrot, C.; Ferguson, K.M.; Garrett, T.P.J.; Leahy, D.J.; Lemmon, M.A.; Sliwkowski, M.X.; Ward, C.W.; Yokoyama, S. An Open-and-Shut Case? Recent Insights into the Activation of EGF/ErbB Receptors. Mol. Cell 2003, 12, 541-552. [CrossRef]

101. Blume-Jensen, P.; Hunter, T. Oncogenic Kinase Signalling. Nature 2001, 411, 355-365. [CrossRef]

102. Siwak, D.R.; Carey, M.; Hennessy, B.T.; Nguyen, C.T.; McGahren Murray, M.J.; Nolden, L.; Mills, G.B. Targeting the Epidermal Growth Factor Receptor in Epithelial Ovarian Cancer: Current Knowledge and Future Challenges. J. Oncol. 2010, 2010. [CrossRef]

103. Veloso, E.S.; Gonçalves, I.N.N.; Silveira, T.L.; Oliveira, F.S.; Vieira, D.S.; Cassali, G.D.; Del Puerto, H.L.; Ferreira, E. Diverse Roles of Epidermal Growth Factors Receptors in Oral and Cutaneous Canine Melanomas. BMC Vet. Res. 2020, 16, 24. [CrossRef] [PubMed]

104. Koprowski, H.; Herlyn, M.; Balaban, G.; Parmiter, A.; Ross, A.; Nowell, P. Expression of the Receptor for Epidermal Growth Factor Correlates with Increased Dosage of Chromosome 7 in Malignant Melanoma. Somat. Cell Mol. Genet. 1985, 11, $297-302$. [CrossRef] [PubMed]

105. De Wit, P.E.; Moretti, S.; Koenders, P.G.; Weterman, M.A.; van Muijen, G.N.; Gianotti, B.; Ruiter, D.J. Increasing Epidermal Growth Factor Receptor Expression in Human Melanocytic Tumor Progression. J. Investig. Dermatol. 1992, 99, 168-173. [CrossRef] [PubMed]

106. Huang, T.S.; Rauth, S.; Das Gupta, T.K. Overexpression of EGF Receptor Is Associated with Spontaneous Metastases of a Human Melanoma Cell Line in Nude Mice. Anticancer Res. 1996, 16, 3557-3563. [PubMed]

107. Mattei, S.; Colombo, M.P.; Melani, C.; Silvani, A.; Parmiani, G.; Herlyn, M. Expression of Cytokine/Growth Factors and Their Receptors in Human Melanoma and Melanocytes. Int. J. Cancer 1994, 56, 853-857. [CrossRef] [PubMed]

108. Simiczyjew, A.; Pietraszek-Gremplewicz, K.; Dratkiewicz, E.; Podgórska, M.; Matkowski, R.; Ziętek, M.; Nowak, D. Combination of Selected MET and EGFR Inhibitors Decreases Melanoma Cells' Invasive Abilities. Front. Pharmacol. 2019, 10. [CrossRef] [PubMed]

109. Pearlman, R.L.; de Oca, M.K.M.; Pal, H.C.; Afaq, F. Potential Therapeutic Targets of Epithelial-Mesenchymal Transition in Melanoma. Cancer Lett. 2017, 391, 125-140. [CrossRef]

110. Girotti, M.R.; Pedersen, M.; Sanchez-Laorden, B.; Viros, A.; Turajlic, S.; Niculescu-Duvaz, D.; Zambon, A.; Sinclair, J.; Hayes, A.; Gore, M.; et al. Inhibiting EGF Receptor or SRC Family Kinase Signaling Overcomes BRAF Inhibitor Resistance in Melanoma. Cancer Discov. 2013, 3, 158-167. [CrossRef]

111. Luebker, S.A.; Koepsell, S.A. Diverse Mechanisms of BRAF Inhibitor Resistance in Melanoma Identified in Clinical and Preclinical Studies. Front. Oncol. 2019, 9. [CrossRef]

112. EGFR Inhibitors-An Overview I ScienceDirect Topics. Available online: https:/ /www.sciencedirect.com/topics/medicine-anddentistry/egfr-inhibitors (accessed on 29 April 2020).

113. Penne, K.; Bohlin, C.; Schneider, S.; Allen, D. Gefitinib (Iressa, ZD1839) and Tyrosine Kinase Inhibitors: The Wave of the Future in Cancer Therapy. Cancer Nurs. 2005, 28, 481-486. [CrossRef] [PubMed]

114. Djerf, E.A.; Trinks, C.; Abdiu, A.; Thunell, L.K.; Hallbeck, A.-L.; Walz, T.M. ErbB Receptor Tyrosine Kinases Contribute to Proliferation of Malignant Melanoma Cells: Inhibition by Gefitinib (ZD1839). Melanoma Res. 2009, 19, 156-166. [CrossRef]

115. Patel, S.P.; Kim, K.B.; Papadopoulos, N.E.; Hwu, W.-J.; Hwu, P.; Prieto, V.G.; Bar-Eli, M.; Zigler, M.; Dobroff, A.; Bronstein, Y.; et al. A Phase II Study of Gefitinib in Patients with Metastatic Melanoma. Melanoma Res. 2011, 21, 357-363. [CrossRef] [PubMed]

116. Wan, X.; Zhu, Y.; Zhang, L.; Hou, W. Gefitinib Inhibits Malignant Melanoma Cells through the VEGF/AKT Signaling Pathway. Mol. Med. Rep. 2018, 17, 7351-7355. [CrossRef]

117. Kenessey, I.; Kramer, Z.; István, L.; Cserepes, M.T.; Garay, T.; Hegedûs, B.; Dobos, J.; Tímár, J.; Tóvári, J. Inhibition of Epidermal Growth Factor Receptor Improves Antitumor Efficacy of Vemurafenib in BRAF-Mutant Human Melanoma in Preclinical Model. Melanoma Res. 2018, 28, 536-546. [CrossRef]

118. Schicher, N.; Paulitschke, V.; Swoboda, A.; Kunstfeld, R.; Loewe, R.; Pilarski, P.; Pehamberger, H.; Hoeller, C. Erlotinib and Bevacizumab Have Synergistic Activity against Melanoma. Clin. Cancer Res. 2009, 15, 3495-3502. [CrossRef]

119. Deng, W.-G.; Kwon, J.; Ekmekcioglu, S.; Poindexter, N.J.; Grimm, E.A. IL-24 Gene Transfer Sensitizes Melanoma Cells to Erlotinib through Modulation of the Apaf-1 and Akt Signaling Pathways. Melanoma Res. 2011, 21, 44-56. [CrossRef]

120. Dratkiewicz, E.; Pietraszek-Gremplewicz, K.; Simiczyjew, A.; Mazur, A.J.; Nowak, D. Gefitinib or Lapatinib with Foretinib Synergistically Induce a Cytotoxic Effect in Melanoma Cell Lines. Oncotarget 2018, 9, 18254-18268. [CrossRef] 
121. Dratkiewicz, E.; Simiczyjew, A.; Pietraszek-Gremplewicz, K.; Mazurkiewicz, J.; Nowak, D. Characterization of Melanoma Cell Lines Resistant to Vemurafenib and Evaluation of Their Responsiveness to EGFR- and MET-Inhibitor Treatment. Int. J. Mol. Sci. 2019, 21, 113. [CrossRef]

122. Held, M.A.; Langdon, C.G.; Platt, J.T.; Graham-Steed, T.; Liu, Z.; Chakraborty, A.; Bacchiocchi, A.; Koo, A.; Bosenberg, M.W.; Stern, D.F. Genotype-Selective Combination Therapies for Melanoma Identified by High Throughput Drug Screening. Cancer Discov. 2013, 3, 52-67. [CrossRef]

123. Das, I.; Wilhelm, M.; Höiom, V.; Franco Marquez, R.; Costa Svedman, F.; Hansson, J.; Tuominen, R.; Egyhàzi Brage, S. Combining ERBB Family and MET Inhibitors Is an Effective Therapeutic Strategy in Cutaneous Malignant Melanoma Independent of BRAF/NRAS Mutation Status. Cell Death Dis. 2019, 10. [CrossRef]

124. Mudigonda, T.V.; Wyman, K.; Spigel, D.R.; Dahlman, K.B.; Greco, F.A.; Puzanov, I.; Kelley, M.C.; Hainsworth, J.D.; Sosman, J.A.; Johnson, D.B. A Phase II Trial of Erlotinib and Bevacizumab for Patients with Metastatic Melanoma. Pigment Cell Melanoma Res. 2016, 29, 101-103. [CrossRef] [PubMed]

125. Erlotinib-an Overview ScienceDirect Topics. Available online: https://www.sciencedirect.com/topics/medicine-and-dentistry/ erlotinib (accessed on 30 April 2020).

126. Cohen, M.H.; Johnson, J.R.; Chen, Y.-F.; Sridhara, R.; Pazdur, R. FDA Drug Approval Summary: Erlotinib (Tarceva) Tablets. Oncologist 2005, 10, 461-466. [CrossRef] [PubMed]

127. Loss of Novel Mda-7 Splice Variant (Mda-7s) Expression Is Associated with Metastatic Melanoma.-PubMed-NCBI. Available online: https: / / www.ncbi.nlm.nih.gov/pubmed/15304100 (accessed on 1 May 2020).

128. Ekmekcioglu, S.; Ellerhorst, J.A.; Mumm, J.B.; Zheng, M.; Broemeling, L.; Prieto, V.G.; Stewart, A.L.; Mhashilkar, A.M.; Chada, S.; Grimm, E.A. Negative Association of Melanoma Differentiation-Associated Gene (Mda-7) and Inducible Nitric Oxide Synthase (INOS) in Human Melanoma: MDA-7 Regulates INOS Expression in Melanoma Cells. Mol. Cancer Ther. 2003, 2, 9-17. [PubMed]

129. Chada, S.; Mhashilkar, A.M.; Ramesh, R.; Mumm, J.B.; Sutton, R.B.; Bocangel, D.; Zheng, M.; Grimm, E.A.; Ekmekcioglu, S. Bystander Activity of Ad-Mda7: Human MDA-7 Protein Kills Melanoma Cells via an IL-20 Receptor-Dependent but STAT3Independent Mechanism. Mol. Ther. 2004, 10, 1085-1095. [CrossRef] [PubMed]

130. Lebedeva, I.V.; Su, Z.-Z.; Sarkar, D.; Kitada, S.; Dent, P.; Waxman, S.; Reed, J.C.; Fisher, P.B. Melanoma Differentiation Associated Gene-7, Mda-7/Interleukin-24, Induces Apoptosis in Prostate Cancer Cells by Promoting Mitochondrial Dysfunction and Inducing Reactive Oxygen Species. Cancer Res. 2003, 63, 8138-8144.

131. Ekmekcioglu, S.; Mumm, J.B.; Udtha, M.; Chada, S.; Grimm, E.A. Killing of Human Melanoma Cells Induced by Activation of Class I Interferon-Regulated Signaling Pathways via MDA-7/IL-24. Cytokine 2008, 43, 34-44. [CrossRef]

132. Bocangel, D.; Zheng, M.; Mhashilkar, A.; Liu, Y.; Ramesh, R.; Hunt, K.; Chada, S. Combinatorial Synergy Induced by AdenoviralMediated Mda-7 and Herceptin in Her-2 p Breast Cancer Cells. Cancer Gene Ther. 2006, 13, 958-968. [CrossRef]

133. Emdad, L.; Lebedeva, I.V.; Su, Z.-Z.; Gupta, P.; Sarkar, D.; Settleman, J.; Fisher, P.B. Combinatorial Treatment of Non-Small-Cell Lung Cancers with Gefitinib and Ad.Mda-7 Enhances Apoptosis-Induction and Reverses Resistance to a Single Therapy. J. Cell. Physiol. 2007, 210, 549-559. [CrossRef] [PubMed]

134. Wood, E.R.; Truesdale, A.T.; McDonald, O.B.; Yuan, D.; Hassell, A.; Dickerson, S.H.; Ellis, B.; Pennisi, C.; Horne, E.; Lackey, K.; et al. A Unique Structure for Epidermal Growth Factor Receptor Bound to GW572016 (Lapatinib): Relationships among Protein Conformation, Inhibitor off-Rate, and Receptor Activity in Tumor Cells. Cancer Res. 2004, 64, 6652-6659. [CrossRef] [PubMed]

135. Manzano, J.L.; Layos, L.; Bugés, C.; de Los Llanos Gil, M.; Vila, L.; Martínez-Balibrea, E.; Martínez-Cardús, A. Resistant Mechanisms to BRAF Inhibitors in Melanoma. Ann. Transl. Med. 2016, 4, 237. [CrossRef] [PubMed]

136. Yu, H.A.; Riely, G.J. Second Generation Epidermal Growth Factor Receptor Tyrosine Kinase Inhibitors in Lung Cancers. J. Natl. Compr. Cancer Netw. 2013, 11, 161-169. [CrossRef] [PubMed]

137. Landi, L.; Cappuzzo, F. Irreversible EGFR-TKIs: Dreaming Perfection. Transl. Lung Cancer Res. 2013, 2, 40-49. [CrossRef] [PubMed]

138. Dungo, R.T.; Keating, G.M. Afatinib: First Global Approval. Drugs 2013, 73, 1503-1515. [CrossRef]

139. Cecchi, F.; Rabe, D.C.; Bottaro, D.P. The Hepatocyte Growth Factor Receptor: Structure, Function and Pharmacological Targeting in Cancer. Curr. Signal Transduct. Ther. 2011, 6, 146-151. [CrossRef] [PubMed]

140. Bottaro, D.P.; Rubin, J.S.; Faletto, D.L.; Chan, A.M.; Kmiecik, T.E.; Vande Woude, G.F.; Aaronson, S.A. Identification of the Hepatocyte Growth Factor Receptor as the C-Met Proto-Oncogene Product. Science 1991, 251, 802-804. [CrossRef]

141. Ronsin, C.; Muscatelli, F.; Mattei, M.G.; Breathnach, R. A Novel Putative Receptor Protein Tyrosine Kinase of the Met Family. Oncogene 1993, 8, 1195-1202.

142. Medico, E.; Mongiovi, A.M.; Huff, J.; Jelinek, M.A.; Follenzi, A.; Gaudino, G.; Parsons, J.T.; Comoglio, P.M. The Tyrosine Kinase Receptors Ron and Sea Control "Scattering" and Morphogenesis of Liver Progenitor Cells in Vitro. Mol. Biol. Cell 1996, 7, 495-504. [CrossRef] [PubMed]

143. Jung, K.H.; Park, B.H.; Hong, S.-S. Progress in Cancer Therapy Targeting C-Met Signaling Pathway. Arch. Pharm. Res. 2012, 35, 595-604. [CrossRef]

144. Kozlov, G.; Perreault, A.; Schrag, J.D.; Park, M.; Cygler, M.; Gehring, K.; Ekiel, I. Insights into Function of PSI Domains from Structure of the Met Receptor PSI Domain. Biochem. Biophys. Res. Commun. 2004, 321, 234-240. [CrossRef] [PubMed] 
145. Gherardi, E.; Youles, M.E.; Miguel, R.N.; Blundell, T.L.; Iamele, L.; Gough, J.; Bandyopadhyay, A.; Hartmann, G.; Butler, P.J.G. Functional Map and Domain Structure of MET, the Product of the c-Met Protooncogene and Receptor for Hepatocyte Growth Factor/Scatter Factor. Proc. Natl. Acad. Sci. USA 2003, 100, 12039-12044. [CrossRef] [PubMed]

146. A High Affinity Hepatocyte Growth Factor-Binding Site in the Immunoglobulin-like Region of Met. Available online: https: / /www.ncbi.nlm.nih.gov/pmc/articles/PMC2475716/ (accessed on 4 May 2020).

147. Kong-Beltran, M.; Stamos, J.; Wickramasinghe, D. The Sema Domain of Met Is Necessary for Receptor Dimerization and Activation. Cancer Cell 2004, 6, 75-84. [CrossRef]

148. Stamos, J.; Lazarus, R.A.; Yao, X.; Kirchhofer, D.; Wiesmann, C. Crystal Structure of the HGF $\beta$-Chain in Complex with the Sema Domain of the Met Receptor. EMBO J. 2004, 23, 2325-2335. [CrossRef]

149. Corso, S.; Comoglio, P.M.; Giordano, S. Cancer Therapy: Can the Challenge Be MET? Trends Mol. Med. 2005, 11, 284-292. [CrossRef]

150. Zhang, Y.-W.; Vande Woude, G.F. HGF/SF-Met Signaling in the Control of Branching Morphogenesis and Invasion. J. Cell. Biochem. 2003, 88, 408-417. [CrossRef]

151. Organ, S.L.; Tsao, M.-S. An Overview of the C-MET Signaling Pathway. Ther. Adv. Med. Oncol. 2011, 3, S7-S19. [CrossRef] [PubMed]

152. Ma, P.C.; Kijima, T.; Maulik, G.; Fox, E.A.; Sattler, M.; Griffin, J.D.; Johnson, B.E.; Salgia, R. C-MET Mutational Analysis in Small Cell Lung Cancer: Novel Juxtamembrane Domain Mutations Regulating Cytoskeletal Functions. Cancer Res. 2003, 63, 6272-6281. [PubMed]

153. Schmidt, L.; Duh, F.M.; Chen, F.; Kishida, T.; Glenn, G.; Choyke, P.; Scherer, S.W.; Zhuang, Z.; Lubensky, I.; Dean, M.; et al. Germline and Somatic Mutations in the Tyrosine Kinase Domain of the MET Proto-Oncogene in Papillary Renal Carcinomas. Nat. Genet. 1997, 16, 68-73. [CrossRef]

154. Parikh, R.A.; Wang, P.; Beumer, J.H.; Chu, E.; Appleman, L.J. The Potential Roles of Hepatocyte Growth Factor (HGF)-MET Pathway Inhibitors in Cancer Treatment. OncoTargets Ther. 2014, 7, 969-983. [CrossRef]

155. Caenepeel, S.; Cooke, K.; Wadsworth, S.; Huang, G.; Robert, L.; Moreno, B.H.; Parisi, G.; Cajulis, E.; Kendall, R.; Beltran, P.; et al. MAPK Pathway Inhibition Induces MET and GAB1 Levels, Priming BRAF Mutant Melanoma for Rescue by Hepatocyte Growth Factor. Oncotarget 2017, 8, 17795-17809. [CrossRef] [PubMed]

156. Al-U'datt, D.G.F.; Al-Husein, B.A.A.; Qasaimeh, G.R. A Mini-Review of c-Met as a Potential Therapeutic Target in Melanoma. Biomed. Pharmacother. 2017, 88, 194-202. [CrossRef]

157. Zaidi, M.R.; Fisher, D.E.; Rizos, H. Biology of Melanocytes and Primary Melanoma. In Cutaneous Melanoma; Balch, C.M., Atkins, M.B., Garbe, C., Gershenwald, J.E., Halpern, A.C., Kirkwood, J.M., McArthur, G.A., Thompson, J.F., Sober, A.J., Eds.; Springer International Publishing: Cham, Switzerland, 2020; pp. 3-40. ISBN 978-3-030-05070-2.

158. Cruz, J.; Reis-Filho, J.S.; Silva, P.; Lopes, J.M. Expression of C-Met Tyrosine Kinase Receptor Is Biologically and Prognostically Relevant for Primary Cutaneous Malignant Melanomas. Oncology 2003, 65, 72-82. [CrossRef]

159. Moore, S.R.; Persons, D.L.; Sosman, J.A.; Bobadilla, D.; Bedell, V.; Smith, D.D.; Wolman, S.R.; Tuthill, R.J.; Moon, J.; Sondak, V.K.; et al. Detection of Copy Number Alterations in Metastatic Melanoma by a DNA Fluorescence in Situ Hybridization Probe Panel and Array Comparative Genomic Hybridization: A Southwest Oncology Group Study (S9431). Clin. Cancer Res. 2008, 14, 2927-2935. [CrossRef]

160. Li, G.; Schaider, H.; Satyamoorthy, K.; Hanakawa, Y.; Hashimoto, K.; Herlyn, M. Downregulation of E-Cadherin and Desmoglein 1 by Autocrine Hepatocyte Growth Factor during Melanoma Development. Oncogene 2001, 20, 8125-8135. [CrossRef]

161. Beuret, L.; Flori, E.; Denoyelle, C.; Bille, K.; Busca, R.; Picardo, M.; Bertolotto, C.; Ballotti, R. Up-Regulation of MET Expression by Alpha-Melanocyte-Stimulating Hormone and MITF Allows Hepatocyte Growth Factor to Protect Melanocytes and Melanoma Cells from Apoptosis. J. Biol. Chem. 2007, 282, 14140-14147. [CrossRef]

162. Chattopadhyay, C.; Ellerhorst, J.A.; Ekmekcioglu, S.; Greene, V.R.; Davies, M.A.; Grimm, E.A. Association of Activated C-Met with NRAS-Mutated Human Melanomas. Int. J. Cancer 2012, 131, E56-E65. [CrossRef] [PubMed]

163. Straussman, R.; Morikawa, T.; Shee, K.; Barzily-Rokni, M.; Qian, Z.R.; Du, J.; Davis, A.; Mongare, M.M.; Gould, J.; Frederick, D.T.; et al. Tumour Micro-Environment Elicits Innate Resistance to RAF Inhibitors through HGF Secretion. Nature 2012, 487, 500-504. [CrossRef] [PubMed]

164. Wilson, T.R.; Fridlyand, J.; Yan, Y.; Penuel, E.; Burton, L.; Chan, E.; Peng, J.; Lin, E.; Wang, Y.; Sosman, J.; et al. Widespread Potential for Growth-Factor-Driven Resistance to Anticancer Kinase Inhibitors. Nature 2012, 487, 505-509. [CrossRef]

165. Comoglio, P.M.; Giordano, S.; Trusolino, L. Drug Development of MET Inhibitors: Targeting Oncogene Addiction and Expedience. Nat. Rev. Drug Discov. 2008, 7, 504-516. [CrossRef]

166. Berthou, S.; Aebersold, D.M.; Schmidt, L.S.; Stroka, D.; Heigl, C.; Streit, B.; Stalder, D.; Gruber, G.; Liang, C.; Howlett, A.R.; et al. The Met Kinase Inhibitor SU11274 Exhibits a Selective Inhibition Pattern toward Different Receptor Mutated Variants. Oncogene 2004, 23, 5387-5393. [CrossRef] [PubMed]

167. Puri, N.; Ahmed, S.; Janamanchi, V.; Tretiakova, M.; Zumba, O.; Krausz, T.; Jagadeeswaran, R.; Salgia, R. C-Met Is a Potentially New Therapeutic Target for Treatment of Human Melanoma. Clin. Cancer Res. 2007, 13, 2246-2253. [CrossRef] [PubMed]

168. Kenessey, I.; Keszthelyi, M.; Krámer, Z.; Berta, J.; Adám, A.; Dobos, J.; Mildner, M.; Flachner, B.; Cseh, S.; Barna, G.; et al. Inhibition of C-Met with the Specific Small Molecule Tyrosine Kinase Inhibitor SU11274 Decreases Growth and Metastasis Formation of Experimental Human Melanoma. Curr. Cancer Drug Targets 2010, 10, 332-342. [CrossRef] [PubMed] 
169. Kucerova, L.; Demkova, L.; Skolekova, S.; Bohovic, R.; Matuskova, M. Tyrosine Kinase Inhibitor SU11274 Increased Tumorigenicity and Enriched for Melanoma-Initiating Cells by Bioenergetic Modulation. BMC Cancer 2016, 16. [CrossRef] [PubMed]

170. Etnyre, D.; Stone, A.L.; Fong, J.T.; Jacobs, R.J.; Uppada, S.B.; Botting, G.M.; Rajanna, S.; Moravec, D.N.; Shambannagari, M.R.; Crees, Z.; et al. Targeting C-Met in Melanoma. Cancer Biol. Ther. 2014, 15, 1129-1141. [CrossRef] [PubMed]

171. Kumar, S.R.; Gajagowni, S.; Bryan, J.N.; Bodenhausen, H.M. Molecular Targets for Tivantinib (ARQ 197) and Vasculogenic Mimicry in Human Melanoma Cells. Eur. J. Pharmacol. 2019, 853, 316-324. [CrossRef]

172. Cao, H.-H.; Cheng, C.-Y.; Su, T.; Fu, X.-Q.; Guo, H.; Li, T.; Tse, A.K.-W.; Kwan, H.-Y.; Yu, H.; Yu, Z.-L. Quercetin Inhibits HGF/c-Met Signaling and HGF-Stimulated Melanoma Cell Migration and Invasion. Mol. Cancer 2015, 14. [CrossRef]

173. Parsons, B.M.; Meier, D.R.; Gurda, G.T.; Lofgren, K.A.; Kenny, P.A. Exceptional Response to Crizotinib in an MET-Amplified Triple-Negative Breast Tumor. JCO Precis. Oncol. 2017, 1, 1-6. [CrossRef]

174. Crizotinib, a c-Met Inhibitor, Prevents Metastasis in a Metastatic Uveal Melanoma Model-PubMed-NCBI. Available online: https:/ / www.ncbi.nlm.nih.gov/pubmed/24140933 (accessed on 6 May 2020).

175. Adjei, A.A.; Schwartz, B.; Garmey, E. Early Clinical Development of ARQ 197, a Selective, Non-ATP-Competitive Inhibitor Targeting MET Tyrosine Kinase for the Treatment of Advanced Cancers. Oncologist 2011, 16, 788-799. [CrossRef]

176. Jeay, S.; Munshi, N.; Hill, J.; Moussa, M.; Ashwell, M.; Leggett, D.; Li, C. ARQ 197, a Highly Selective Small Molecule Inhibitor of c-Met, with Selective Antitumor Properties in a Broad Spectrum of Human Cancer Cells. Cancer Res. 2007, 67, 2369.

177. Jahangiri, A.; De Lay, M.; Miller, L.M.; Carbonell, W.S.; Hu, Y.-L.; Lu, K.; Tom, M.W.; Paquette, J.; Tokuyasu, T.A.; Tsao, S.; et al. Gene Expression Profile Identifies Tyrosine Kinase C-Met as a Targetable Mediator of Antiangiogenic Therapy Resistance. Clin. Cancer Res. 2013, 19, 1773-1783. [CrossRef] [PubMed]

178. Puzanov, I.; Sosman, J.; Santoro, A.; Saif, M.W.; Goff, L.; Dy, G.K.; Zucali, P.; Means-Powell, J.A.; Ma, W.W.; Simonelli, M.; et al. Phase 1 Trial of Tivantinib in Combination with Sorafenib in Adult Patients with Advanced Solid Tumors. Investig. New Drugs 2015, 33, 159-168. [CrossRef]

179. Cao, H.-H.; Tse, A.K.-W.; Kwan, H.-Y.; Yu, H.; Cheng, C.-Y.; Su, T.; Fong, W.-F.; Yu, Z.-L. Quercetin Exerts Anti-Melanoma Activities and Inhibits STAT3 Signaling. Biochem. Pharmacol. 2014, 87, 424-434. [CrossRef]

180. Labbé, D.; Provençal, M.; Lamy, S.; Boivin, D.; Gingras, D.; Béliveau, R. The Flavonols Quercetin, Kaempferol, and Myricetin Inhibit Hepatocyte Growth Factor-Induced Medulloblastoma Cell Migration. J. Nutr. 2009, 139, 646-652. [CrossRef] [PubMed]

181. Daud, A.; Kluger, H.M.; Kurzrock, R.; Schimmoller, F.; Weitzman, A.L.; Samuel, T.A.; Moussa, A.H.; Gordon, M.S.; Shapiro, G.I. Phase II Randomised Discontinuation Trial of the MET/VEGF Receptor Inhibitor Cabozantinib in Metastatic Melanoma. Br. J. Cancer 2017, 116, 432-440. [CrossRef]

182. Wheeler, D.L.; Yarden, Y. Receptor Tyrosine Kinases: Family and Subfamilies; Springer: Berlin, Germany, 2015; ISBN 978-3-319-11888-8.

183. Claesson-Welsh, L. Vascular Growth Factors and Angiogenesis; Springer Science \& Business Media: Berlin, Germany, 2012; ISBN 978-3-642-59953-8.

184. Shibuya, M.; Claesson-Welsh, L. Signal Transduction by VEGF Receptors in Regulation of Angiogenesis and Lymphangiogenesis. Exp. Cell Res. 2006, 312, 549-560. [CrossRef] [PubMed]

185. Bruns, A.F.; Herbert, S.P.; Odell, A.F.; Jopling, H.M.; Hooper, N.M.; Zachary, I.C.; Walker, J.H.; Ponnambalam, S. Ligand-Stimulated VEGFR2 Signaling Is Regulated by Co-Ordinated Trafficking and Proteolysis. Traffic 2010, 11, 161-174. [CrossRef]

186. Davis-Smyth, T.; Chen, H.; Park, J.; Presta, L.G.; Ferrara, N. The Second Immunoglobulin-like Domain of the VEGF Tyrosine Kinase Receptor Flt-1 Determines Ligand Binding and May Initiate a Signal Transduction Cascade. EMBO J. 1996, 15, $4919-4927$. [CrossRef]

187. Sawano, A.; Takahashi, T.; Yamaguchi, S.; Aonuma, M.; Shibuya, M. Flt-1 but Not KDR/Flk-1 Tyrosine Kinase Is a Receptor for Placenta Growth Factor, Which Is Related to Vascular Endothelial Growth Factor. Cell Growth Differ. 1996, 7, $213-221$.

188. Rahimi, N. VEGFR-1 and VEGFR-2: Two Non-Identical Twins with a Unique Physiognomy. Front. Biosci. 2006, 11, 818-829. [CrossRef] [PubMed]

189. Autiero, M.; Waltenberger, J.; Communi, D.; Kranz, A.; Moons, L.; Lambrechts, D.; Kroll, J.; Plaisance, S.; De Mol, M.; Bono, F.; et al. Role of PlGF in the Intra- and Intermolecular Cross Talk between the VEGF Receptors Flt1 and Flk1. Nat. Med. 2003, 9, 936-943. [CrossRef] [PubMed]

190. Pajusola, K.; Aprelikova, O.; Pelicci, G.; Weich, H.; Claesson-Welsh, L.; Alitalo, K. Signalling Properties of FLT4, a Proteolytically Processed Receptor Tyrosine Kinase Related to Two VEGF Receptors. Oncogene 1994, 9, 3545-3555. [PubMed]

191. Shinkai, A.; Ito, M.; Anazawa, H.; Yamaguchi, S.; Shitara, K.; Shibuya, M. Mapping of the Sites Involved in Ligand Association and Dissociation at the Extracellular Domain of the Kinase Insert Domain-Containing Receptor for Vascular Endothelial Growth Factor. J. Biol. Chem. 1998, 273, 31283-31288. [CrossRef] [PubMed]

192. Tanaka, K.; Yamaguchi, S.; Sawano, A.; Shibuya, M. Characterization of the Extracellular Domain in Vascular Endothelial Growth Factor Receptor-1 (Flt-1 Tyrosine Kinase). Jpn. J. Cancer Res. 1997, 88, 867-876. [CrossRef]

193. Ruch, C.; Skiniotis, G.; Steinmetz, M.O.; Walz, T.; Ballmer-Hofer, K. Structure of a VEGF-VEGF Receptor Complex Determined by Electron Microscopy. Nat. Struct. Mol. Biol. 2007, 14, 249-250. [CrossRef] [PubMed]

194. Holmes, K.; Roberts, O.L.; Thomas, A.M.; Cross, M.J. Vascular Endothelial Growth Factor Receptor-2: Structure, Function, Intracellular Signalling and Therapeutic Inhibition. Cell. Signal. 2007, 19, 2003-2012. [CrossRef] [PubMed]

195. Manni, S. Structural and Functional Characterization of the Intracellular Kinase Domain of Vascular Endothelial Growth Factor Receptor-2. Ph.D. Thesis, University of Basel, Basel, Switzerland, 21 May 2013. 
196. Shibuya, M. Vascular Endothelial Growth Factor (VEGF) and Its Receptor (VEGFR) Signaling in Angiogenesis. Genes Cancer 2011, 2, 1097-1105. [CrossRef]

197. Rajabi, P.; Neshat, A.; Mokhtari, M.; Rajabi, M.A.; Eftekhari, M.; Tavakoli, P. The Role of VEGF in Melanoma Progression. J. Res. Med. Sci. 2012, 17, 534-539. [PubMed]

198. Sini, P.; Baffert, F.; Wood, J.; Hynes, N.E. Role of VEGFR Signaling in Tumor Cells. Cancer Res. 2006, 66, 659.

199. Simonetti, O.; Lucarini, G.; Brancorsini, D.; Nita, P.; Bernardini, M.L.; Biagini, G.; Offidani, A. Immunohistochemical Expression of Vascular Endothelial Growth Factor, Matrix Metalloproteinase 2, and Matrix Metalloproteinase 9 in Cutaneous Melanocytic Lesions. Cancer 2002, 95, 1963-1970. [CrossRef] [PubMed]

200. Potti, A.; Moazzam, N.; Tendulkar, K.; Javed, N.A.; Koch, M.; Kargas, S. Immunohistochemical Determination of Vascular Endothelial Growth Factor (VEGF) Overexpression in Malignant Melanoma. Anticancer Res. 2003, 23, 4023-4026. [PubMed]

201. Graells, J.; Vinyals, A.; Figueras, A.; Llorens, A.; Moreno, A.; Marcoval, J.; Gonzalez, F.J.; Fabra, A. Overproduction of VEGF Concomitantly Expressed with Its Receptors Promotes Growth and Survival of Melanoma Cells through MAPK and PI3K Signaling. J. Investig. Dermatol. 2004, 123, 1151-1161. [CrossRef] [PubMed]

202. Goydos, J.S.; Gorski, D.H. Vascular Endothelial Growth Factor C MRNA Expression Correlates with Stage of Progression in Patients with Melanoma. Clin. Cancer Res. 2003, 9, 5962-5967.

203. Ugurel, S.; Rappl, G.; Tilgen, W.; Reinhold, U. Increased Serum Concentration of Angiogenic Factors in Malignant Melanoma Patients Correlates with Tumor Progression and Survival. J. Clin. Oncol. 2001, 19, 577-583. [CrossRef]

204. Atzori, M.G.; Ceci, C.; Ruffini, F.; Trapani, M.; Barbaccia, M.L.; Tentori, L.; D'Atri, S.; Lacal, P.M.; Graziani, G. Role of VEGFR-1 in Melanoma Acquired Resistance to the BRAF Inhibitor Vemurafenib. J. Cell Mol. Med. 2020, 24, 465-475. [CrossRef]

205. Jain, R.K. Normalizing Tumor Vasculature with Anti-Angiogenic Therapy: A New Paradigm for Combination Therapy. Nat. Med. 2001, 7, 987-989. [CrossRef]

206. Mendel, D.B.; Schreck, R.E.; West, D.C.; Li, G.; Strawn, L.M.; Tanciongco, S.S.; Vasile, S.; Shawver, L.K.; Cherrington, J.M. The Angiogenesis Inhibitor SU5416 Has Long-Lasting Effects on Vascular Endothelial Growth Factor Receptor Phosphorylation and Function. Clin. Cancer Res. 2000, 6, 4848-4858. [PubMed]

207. Mendel, D.B.; Laird, A.D.; Smolich, B.D.; Blake, R.A.; Liang, C.; Hannah, A.L.; Shaheen, R.M.; Ellis, L.M.; Weitman, S.; Shawver, L.K.; et al. Development of SU5416, a Selective Small Molecule Inhibitor of VEGF Receptor Tyrosine Kinase Activity, as an Anti-Angiogenesis Agent. Anticancer Drug Des. 2000, 15, $29-41$.

208. Kuenen, B.C.; Tabernero, J.; Baselga, J.; Cavalli, F.; Pfanner, E.; Conte, P.F.; Seeber, S.; Madhusudan, S.; Deplanque, G.; Huisman, H.; et al. Efficacy and Toxicity of the Angiogenesis Inhibitor SU5416 as a Single Agent in Patients with Advanced Renal Cell Carcinoma, Melanoma, and Soft Tissue Sarcoma. Clin. Cancer Res. 2003, 9, 1648-1655.

209. Mita, M.M.; Rowinsky, E.K.; Forero, L.; Eckhart, S.G.; Izbicka, E.; Weiss, G.R.; Beeram, M.; Mita, A.C.; de Bono, J.S.; Tolcher, A.W.; et al. A Phase II, Pharmacokinetic, and Biologic Study of Semaxanib and Thalidomide in Patients with Metastatic Melanoma. Cancer Chemother. Pharmacol. 2007, 59, 165-174. [CrossRef]

210. Hu-Lowe, D.D.; Zou, H.Y.; Grazzini, M.L.; Hallin, M.E.; Wickman, G.R.; Amundson, K.; Chen, J.H.; Rewolinski, D.A.; Yamazaki, S.; Wu, E.Y.; et al. Nonclinical Antiangiogenesis and Antitumor Activities of Axitinib (AG-013736), an Oral, Potent, and Selective Inhibitor of Vascular Endothelial Growth Factor Receptor Tyrosine Kinases 1, 2, 3. Clin. Cancer Res. 2008, 14, 7272-7283. [CrossRef]

211. Fruehauf, J.; Lutzky, J.; McDermott, D.; Brown, C.K.; Meric, J.-B.; Rosbrook, B.; Shalinsky, D.R.; Liau, K.F.; Niethammer, A.G.; Kim, S.; et al. Multicenter, Phase II Study of Axitinib, a Selective Second-Generation Inhibitor of Vascular Endothelial Growth Factor Receptors 1, 2, and 3, in Patients with Metastatic Melanoma. Clin. Cancer Res. 2011, 17, 7462-7469. [CrossRef]

212. Bose, A.; Lowe, D.B.; Rao, A.; Storkus, W.J. Combined Vaccine + Axitinib Therapy Yields Superior Anti-Tumor Efficacy in a Murine Melanoma Model. Melanoma Res. 2012, 22, 236-243. [CrossRef]

213. Algazi, A.P.; Cha, E.; Ortiz-Urda, S.M.; McCalmont, T.; Bastian, B.C.; Hwang, J.; Pampaloni, M.H.; Behr, S.; Chong, K.; Cortez, B.; et al. The Combination of Axitinib Followed by Paclitaxel/Carboplatin Yields Extended Survival in Advanced BRAF Wild-Type Melanoma: Results of a Clinical/Correlative Prospective Phase II Clinical Trial. Br. J. Cancer 2015, 112, 1326-1331. [CrossRef]

214. Study of the Anti-Angiogenesis Agent Axitinib in Patients with Stage III Malignant Melanoma-Full Text View-ClinicalTrials.Gov. Available online: https:/ / clinicaltrials.gov/ct2/show / NCT01321437 (accessed on 18 May 2020).

215. Guo, J. A Monocentric, Single-Arm, Open, Phase II Clinical Study on the Efficacy and Safety of Toripalimab Combined with Axitinib as Neoadjuvant Therapy in Patients with Localized Mucosal Melanoma. Available online: clinicaltrials.gov (accessed on 18 May 2020).

216. Varker, K.A.; Biber, J.E.; Kefauver, C.; Jensen, R.; Lehman, A.; Young, D.; Wu, H.; Lesinski, G.B.; Kendra, K.; Chen, H.X.; et al. A Randomized Phase 2 Trial of Bevacizumab with or without Daily Low-Dose Interferon Alfa-2b in Metastatic Malignant Melanoma. Ann. Surg. Oncol. 2007, 14, 2367-2376. [CrossRef]

217. Grignol, V.P.; Olencki, T.; Relekar, K.; Taylor, C.; Kibler, A.; Kefauver, C.; Wei, L.; Walker, M.J.; Chen, H.X.; Kendra, K.; et al. A Phase II Trial of Bevacizumab and High Dose Interferon Alpha-2B in Metastatic Melanoma. J. Immunother. 2011, 34, 509-515. [CrossRef] [PubMed]

218. Kim, K.B.; Sosman, J.A.; Fruehauf, J.P.; Linette, G.P.; Markovic, S.N.; McDermott, D.F.; Weber, J.S.; Nguyen, H.; Cheverton, P.; Chen, D.; et al. BEAM: A Randomized Phase II Study Evaluating the Activity of Bevacizumab in Combination with Carboplatin Plus Paclitaxel in Patients with Previously Untreated Advanced Melanoma. J. Clin. Oncol. 2012, 30, 34-41. [CrossRef] 
219. Corrie, P.G.; Marshall, A.; Nathan, P.D.; Lorigan, P.; Gore, M.; Tahir, S.; Faust, G.; Kelly, C.G.; Marples, M.; Danson, S.J.; et al. Adjuvant Bevacizumab for Melanoma Patients at High Risk of Recurrence: Survival Analysis of the AVAST-M Trial. Ann. Oncol. 2018, 29, 1843-1852. [CrossRef] [PubMed]

220. Simonsen, T.G.; Gaustad, J.-V.; Rofstad, E.K. Bevacizumab Treatment of Meningeal Melanoma Metastases. J. Transl. Med. 2020, 18, 13. [CrossRef] [PubMed]

221. Yakes, F.M.; Chen, J.; Tan, J.; Yamaguchi, K.; Shi, Y.; Yu, P.; Qian, F.; Chu, F.; Bentzien, F.; Cancilla, B.; et al. Cabozantinib (XL184), a Novel MET and VEGFR2 Inhibitor, Simultaneously Suppresses Metastasis, Angiogenesis, and Tumor Growth. Mol. Cancer Ther. 2011, 10, 2298-2308. [CrossRef]

222. Grüllich, C. Cabozantinib: Multi-Kinase Inhibitor of MET, AXL, RET, and VEGFR2. Recent Results Cancer Res. 2018, 211, 67-75. [CrossRef]

223. Kurzrock, R.; Sherman, S.I.; Ball, D.W.; Forastiere, A.A.; Cohen, R.B.; Mehra, R.; Pfister, D.G.; Cohen, E.E.W.; Janisch, L.; Nauling, F.; et al. Activity of XL184 (Cabozantinib), an Oral Tyrosine Kinase Inhibitor, in Patients with Medullary Thyroid Cancer. J. Clin. Oncol. 2011, 29, 2660-2666. [CrossRef]

224. Vergani, E.; Vallacchi, V.; Frigerio, S.; Deho, P.; Mondellini, P.; Perego, P.; Cassinelli, G.; Lanzi, C.; Testi, M.A.; Rivoltini, L.; et al. Identification of MET and SRC Activation in Melanoma Cell Lines Showing Primary Resistance to PLX4032. Neoplasia 2011, 13, 1132-1142. [CrossRef]

225. Cabozantinib and Pembrolizumab for Advanced Metastatic Melanoma-Full Text View-ClinicalTrials.Gov. Available online: https:/ / clinicaltrials.gov/ct2/show / NCT03957551 (accessed on 4 September 2020).

226. Nivolumab/Ipilimumab Plus Cabozantinib in Patients with Unresectable Advanced Melanoma-Full Text View-ClinicalTrials.Gov. Available online: https:/ / clinicaltrials.gov/ct2/show/NCT04091750 (accessed on 4 September 2020).

227. Dufies, M.; Jacquel, A.; Robert, G.; Cluzeau, T.; Puissant, A.; Fenouille, N.; Legros, L.; Raynaud, S.; Cassuto, J.-P.; Luciano, F.; et al. Mechanism of Action of the Multikinase Inhibitor Foretinib. Cell Cycle 2011, 10, 4138-4148. [CrossRef] [PubMed]

228. Qian, F.; Engst, S.; Yamaguchi, K.; Yu, P.; Won, K.-A.; Mock, L.; Lou, T.; Tan, J.; Li, C.; Tam, D.; et al. Inhibition of Tumor Cell Growth, Invasion, and Metastasis by EXEL-2880 (XL880, GSK1363089), a Novel Inhibitor of HGF and VEGF Receptor Tyrosine Kinases. Cancer Res. 2009, 69, 8009-8016. [CrossRef]

229. Wang, W.; Li, Q.; Takeuchi, S.; Yamada, T.; Koizumi, H.; Nakamura, T.; Matsumoto, K.; Mukaida, N.; Nishioka, Y.; Sone, S.; et al. Met Kinase Inhibitor E7050 Reverses Three Different Mechanisms of Hepatocyte Growth Factor-Induced Tyrosine Kinase Inhibitor Resistance in EGFR Mutant Lung Cancer. Clin. Cancer Res. 2012, 18, 1663-1671. [CrossRef]

230. E7050 in Combination With E7080 in Subjects With Advanced Solid Tumors (Dose Escalation) and in Subjects With Recurrent Glioblastoma or Unresectable Stage III or Stage IV Melanoma After Prior Systemic Therapy (Expansion Cohort and Phase 2)-No Study Results Posted-ClinicalTrials.Gov. Available online: https:/ / clinicaltrials.gov/ct2/show / results/NCT01433991 (accessed on 8 May 2020).

231. Adams, T.E.; Epa, V.C.; Garrett, T.P.; Ward, C.W. Structure and Function of the Type 1 Insulin-like Growth Factor Receptor. Cell. Mol. Life Sci. 2000, 57, 1050-1093. [CrossRef]

232. Li, J.; Choi, E.; Yu, H.; Bai, X.-C. Structural Basis of the Activation of Type 1 Insulin-like Growth Factor Receptor. Nat. Commun. 2019, 10, 4567. [CrossRef] [PubMed]

233. Kanter-Lewensohn, L.; Dricu, A.; Girnita, L.; Wejde, J.; Larsson, O. Expression of Insulin-like Growth Factor-1 Receptor (IGF-1R) and P27Kip1 in Melanocytic Tumors: A Potential Regulatory Role of IGF-1 Pathway in Distribution of P27Kip1 between Different Cyclins. Growth Factors 2000, 17, 193-202. [CrossRef] [PubMed]

234. Constitutive Expression of Multiple Growth Factor Genes by Melanoma Cells but Not Normal Melanocytes-PubMed. Available online: https: / / pubmed.ncbi.nlm.nih.gov/2056188/ (accessed on 9 March 2021).

235. Hilmi, C.; Larribere, L.; Giuliano, S.; Bille, K.; Ortonne, J.-P.; Ballotti, R.; Bertolotto, C. IGF1 Promotes Resistance to Apoptosis in Melanoma Cells through an Increased Expression of BCL2, BCL-X(L), and Survivin. J. Investig. Dermatol. 2008, 128, 1499-1505. [CrossRef]

236. Wang, J.; Sinnberg, T.; Niessner, H.; Dölker, R.; Sauer, B.; Kempf, W.E.; Meier, F.; Leslie, N.; Schittek, B. PTEN Regulates IGF-1R-Mediated Therapy Resistance in Melanoma. Pigment Cell Melanoma Res. 2015, 28, 572-589. [CrossRef]

237. Schlessinger, J. Receptor Tyrosine Kinases: Legacy of the First Two Decades. Cold Spring Harb. Perspect. Biol. 2014, 6. [CrossRef]

238. Ornitz, D.M.; Itoh, N. The Fibroblast Growth Factor Signaling Pathway. Wiley Interdiscip. Rev. Dev. Biol. 2015, 4, 215-266. [CrossRef]

239. Freier, K.; Schwaenen, C.; Sticht, C.; Flechtenmacher, C.; Mühling, J.; Hofele, C.; Radlwimmer, B.; Lichter, P.; Joos, S. Recurrent FGFR1 Amplification and High FGFR1 Protein Expression in Oral Squamous Cell Carcinoma (OSCC). Oral Oncol. 2007, 43, 60-66. [CrossRef]

240. Wang, Y.; Becker, D. Antisense Targeting of Basic Fibroblast Growth Factor and Fibroblast Growth Factor Receptor-1 in Human Melanomas Blocks Intratumoral Angiogenesis and Tumor Growth. Nat. Med. 1997, 3, 887-893. [CrossRef]

241. Li, L.; Zhang, S.; Li, H.; Chou, H. FGFR3 Promotes the Growth and Malignancy of Melanoma by Influencing EMT and the Phosphorylation of ERK, AKT, and EGFR. BMC Cancer 2019, 19, 963. [CrossRef]

242. Czyz, M. Fibroblast Growth Factor Receptor Signaling in Skin Cancers. Cells 2019, 8. [CrossRef] 
243. Pfizer The LOGIC 2 Trial A Phase II, Multi-Center, Open-Label Study of Sequential LGX818/MEK162 Combination Followed by a Rational Combination with Targeted Agents After Progression, to Overcome Resistance in Adult Patients with Locally Advanced or Metastatic BRAF V600 Melanoma. Available online: clinicaltrials.gov (accessed on 18 May 2020).

244. Zitvogel, L.; Rusakiewicz, S.; Routy, B.; Ayyoub, M.; Kroemer, G. Immunological Off-Target Effects of Imatinib. Nat. Rev. Clin. Oncol. 2016, 13, 431-446. [CrossRef] [PubMed]

245. Finke, J.H.; Rini, B.; Ireland, J.; Rayman, P.; Richmond, A.; Golshayan, A.; Wood, L.; Elson, P.; Garcia, J.; Dreicer, R.; et al. Sunitinib Reverses Type-1 Immune Suppression and Decreases T-Regulatory Cells in Renal Cell Carcinoma Patients. Clin. Cancer Res. 2008, 14, 6674-6682. [CrossRef] [PubMed]

246. De Lavallade, H.; Khoder, A.; Hart, M.; Sarvaria, A.; Sekine, T.; Alsuliman, A.; Mielke, S.; Bazeos, A.; Stringaris, K.; Ali, S.; et al. Tyrosine Kinase Inhibitors Impair B-Cell Immune Responses in CML through off-Target Inhibition of Kinases Important for Cell Signaling. Blood 2013, 122, 227-238. [CrossRef] [PubMed]

247. Dörfel, D.; Lechner, C.J.; Joas, S.; Funk, T.; Gutknecht, M.; Salih, J.; Geiger, J.; Kropp, K.N.; Maurer, S.; Müller, M.R.; et al. The BCR-ABL Inhibitor Nilotinib Influences Phenotype and Function of Monocyte-Derived Human Dendritic Cells. Cancer Immunol. Immunother. 2018, 67, 775-783. [CrossRef]

248. MacDonald, F.; Zaiss, D.M.W. The Immune System's Contribution to the Clinical Efficacy of EGFR Antagonist Treatment. Front. Pharmacol. 2017, 8. [CrossRef]

249. Pollack, B.P. EGFR Inhibitors, MHC Expression and Immune Responses: Can EGFR Inhibitors Be Used as Immune Response Modifiers? Oncoimmunology 2012, 1, 71-74. [CrossRef] [PubMed]

250. Faivre, S.; Delbaldo, C.; Vera, K.; Robert, C.; Lozahic, S.; Lassau, N.; Bello, C.; Deprimo, S.; Brega, N.; Massimini, G.; et al. Safety, Pharmacokinetic, and Antitumor Activity of SU11248, a Novel Oral Multitarget Tyrosine Kinase Inhibitor, in Patients with Cancer. J. Clin. Oncol. 2006, 24, 25-35. [CrossRef]

251. Van Cruijsen, H.; Van Der Veldt, A.A.; Vroling, L.; Oosterhoff, D.; Broxterman, H.J.; Scheper, R.J.; Giaccone, G.; Haanen, J.B.; Eertwegh, A.J.V.D.; Boven, E.; et al. Sunitinib-Induced Myeloid Lineage Redistribution in Renal Cell Cancer Patients: CD1c+ Dendritic Cell Frequency Predicts Progression-Free Survival. Clin. Cancer Res. 2008, 14, 5884-5892. [CrossRef]

252. Papaccio, F.; Della Corte, C.M.; Viscardi, G.; Di Liello, R.; Esposito, G.; Sparano, F.; Ciardiello, F.; Morgillo, F. HGF/MET and the Immune System: Relevance for Cancer Immunotherapy. Int. J. Mol. Sci. 2018, 19. [CrossRef]

253. Glodde, N.; Bald, T.; van den Boorn-Konijnenberg, D.; Nakamura, K.; O’Donnell, J.S.; Szczepanski, S.; Brandes, M.; Eickhoff, S.; Das, I.; Shridhar, N.; et al. Reactive Neutrophil Responses Dependent on the Receptor Tyrosine Kinase C-MET Limit Cancer Immunotherapy. Immunity 2017, 47, 789-802.e9. [CrossRef] [PubMed]

254. Im, J.S.; Herrmann, A.C.; Bernatchez, C.; Haymaker, C.; Molldrem, J.J.; Hong, W.K.; Perez-Soler, R. Immune-Modulation by Epidermal Growth Factor Receptor Inhibitors: Implication on Anti-Tumor Immunity in Lung Cancer. PLoS ONE 2016, 11. [CrossRef] [PubMed]

255. Farsaci, B.; Higgins, J.P.; Hodge, J.W. Consequence of Dose Scheduling of Sunitinib on Host Immune Response Elements and Vaccine Combination Therapy. Int. J. Cancer 2012, 130, 1948-1959. [CrossRef] [PubMed]

256. Motzer, R.J.; Escudier, B.; McDermott, D.F.; George, S.; Hammers, H.J.; Srinivas, S.; Tykodi, S.S.; Sosman, J.A.; Procopio, G.; Plimack, E.R.; et al. Nivolumab versus Everolimus in Advanced Renal Cell Carcinoma. N. Engl. J. Med. 2015, 373, $1803-1813$. [CrossRef] [PubMed] 